Cochrane Database of Systematic Reviews

\title{
Antiemetic medication for prevention and treatment of chemotherapy-induced nausea and vomiting in childhood (Review)
}

Phillips RS, Friend AJ, Gibson F, Houghton E, Gopaul S, Craig JV, Pizer B

Phillips RS, Friend AJ, Gibson F, Houghton E, Gopaul S, Craig JV, Pizer B.

Antiemetic medication for prevention and treatment of chemotherapy-induced nausea and vomiting in childhood.

Cochrane Database of Systematic Reviews 2016, Issue 2. Art. No.: CD007786.

DOI: 10.1002/14651858.CD007786.pub3.

www.cochranelibrary.com

Antiemetic medication for prevention and treatment of chemotherapy-induced nausea and vomiting in childhood (Review) 
TABLE OF CONTENTS

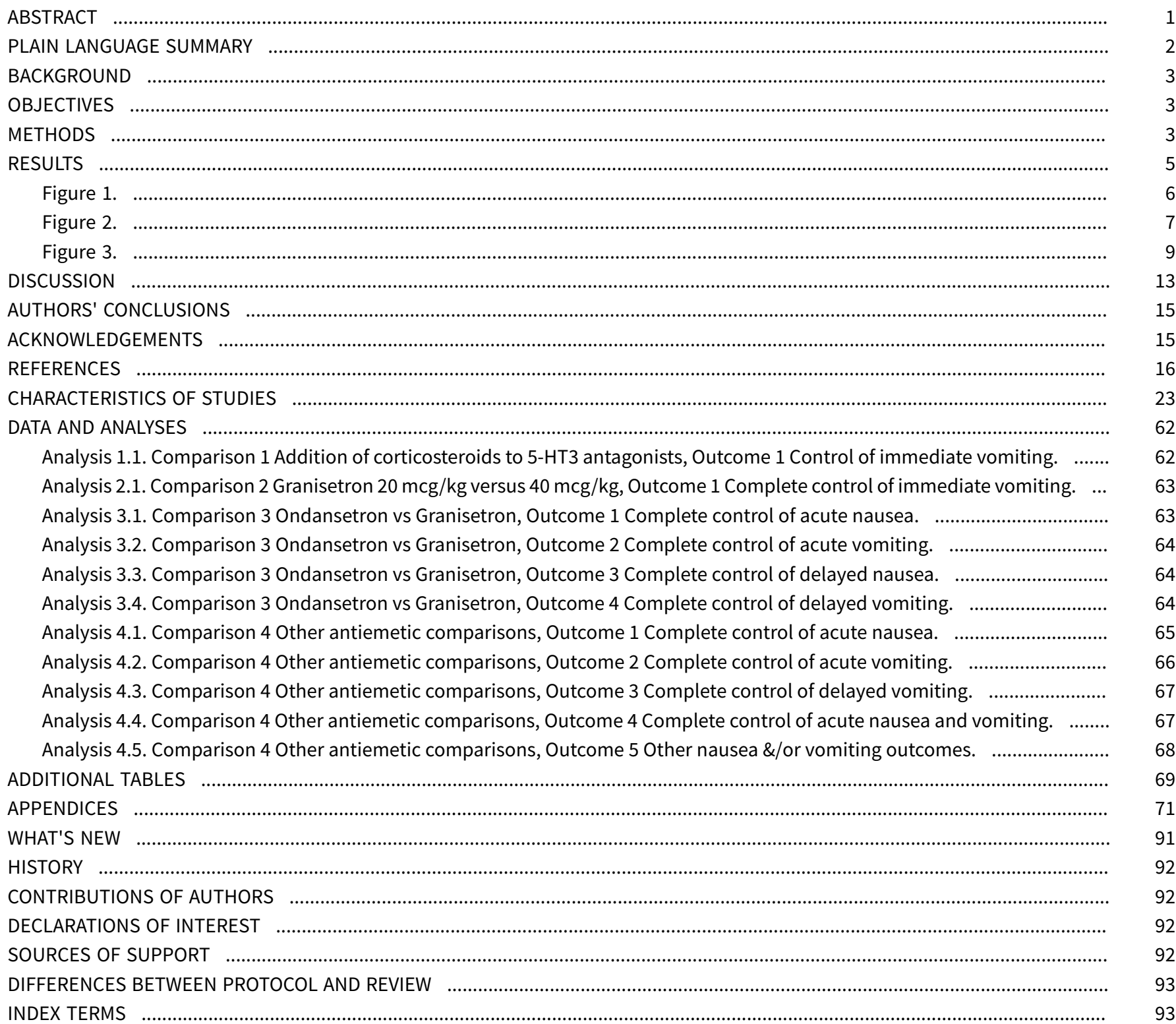


[Intervention Review]

\title{
Antiemetic medication for prevention and treatment of chemotherapy- induced nausea and vomiting in childhood
}

\author{
Robert S Phillips ${ }^{1}$, Amanda J Friend ${ }^{2}$, Faith Gibson ${ }^{3}$, Elizabeth Houghton ${ }^{4}$, Shireen Gopaul ${ }^{5}$, Jean V Craig ${ }^{6}$, Barry Pizer ${ }^{7}$
}

${ }^{1}$ Centre for Reviews and Dissemination, University of York, York, UK. ${ }^{2}$ Community Paediatrics, Leeds Community Healthcare, Leeds, UK. 3Department of Children's Nursing, London South Bank University, London, UK. 4Pharmacy, Alder Hey Children's NHS Foundation Trust, Liverpool, UK. ${ }^{5}$ Section of Experimental Oncology, Leeds Institute of Molecular Medicine/Cancer Research UK Clinical Centre/St James University Hospital, Leeds, UK. ${ }^{6}$ School of Medicine, Health Policy and Practice, Norwich, UK. 7 Oncology Unit, Alder Hey Children's NHS Foundation Trust, Liverpool, UK

Contact: Robert S Phillips, Centre for Reviews and Dissemination, University of York, York, YO10 5DD, UK. bob.phillips@doctors.org.uk.

Editorial group: Cochrane Childhood Cancer Group.

Publication status and date: New search for studies and content updated (no change to conclusions), published in Issue 2, 2016.

Citation: Phillips RS, Friend AJ, Gibson F, Houghton E, Gopaul S, Craig JV, Pizer B. Antiemetic medication for prevention and treatment of chemotherapy-induced nausea and vomiting in childhood. Cochrane Database of Systematic Reviews 2016, Issue 2. Art. No.: CD007786. DOI: 10.1002/14651858.CD007786.pub3.

Copyright ( 2016 The Cochrane Collaboration. Published by John Wiley \& Sons, Ltd.

\section{A B S T R A C T}

\section{Background}

Nausea and vomiting remain a problem for children undergoing treatment for malignancies despite new antiemetic therapies. Optimising antiemetic regimens could improve quality of life by reducing nausea, vomiting, and associated clinical problems. This is an update of the original systematic review.

\section{Objectives}

To assess the effectiveness and adverse events of pharmacological interventions in controlling anticipatory, acute, and delayed nausea and vomiting in children and young people (aged less than 18 years) about to receive or receiving chemotherapy.

\section{Search methods}

Searches included the Cochrane Central Register of Controlled Trials (CENTRAL), MEDLINE, EMBASE, LILACS, PsycINFO, conference proceedings of the American Society of Clinical Oncology, International Society of Paediatric Oncology, Multinational Association of Supportive Care in Cancer, and ISI Science and Technology Proceedings Index from incept to December 16, 2014, and trial registries from their earliest records to December 2014. We examined references of systematic reviews and contacted trialists for information on further studies. We also screened the reference lists of included studies.

\section{Selection criteria}

Two review authors independently screened abstracts in order to identify randomised controlled trials (RCTs) that compared a pharmacological antiemetic, cannabinoid, or benzodiazepine with placebo or any alternative active intervention in children and young people (less than 18 years) with a diagnosis of cancer who were to receive chemotherapy.

\section{Data collection and analysis}

Two review authors independently extracted outcome and quality data from each RCT. When appropriate, we undertook meta-analysis.

\section{Main results}

We included 34 studies that examined a range of different antiemetics, used different doses and comparators, and reported a variety of outcomes. The quality and quantity of included studies limited the exploration of heterogeneity to narrative approaches only. 
The majority of quantitative data related to the complete control of acute vomiting ( 27 studies). Adverse events were reported in 29 studies and nausea outcomes in 16 studies.

Two studies assessed the addition of dexamethasone to $5-\mathrm{HT}_{3}$ antagonists for complete control of vomiting (pooled risk ratio (RR) 2.03; $95 \%$ confidence interval (Cl) 1.35 to 3.04). Three studies compared granisetron $20 \mathrm{mcg} / \mathrm{kg}$ with $40 \mathrm{mcg} / \mathrm{kg}$ for complete control of vomiting (pooled RR $0.93 ; 95 \% \mathrm{Cl} 0.80$ to 1.07). Three studies compared granisetron with ondansetron for complete control of acute nausea (pooled RR 1.05; $95 \% \mathrm{Cl} 0.94$ to $1.17 ; 2$ studies), acute vomiting (pooled RR 2.26; $95 \% \mathrm{Cl} 2.04$ to $2.51 ; 3$ studies), delayed nausea (pooled RR 1.13 ; $95 \%$ $\mathrm{Cl} 0.93$ to $1.38 ; 2$ studies), and delayed vomiting (pooled RR 1.13; $95 \% \mathrm{Cl} 0.98$ to $1.29 ; 2$ studies). No other pooled analyses were possible.

Narrative synthesis suggests that $5-\mathrm{HT}_{3}$ antagonists are more effective than older antiemetic agents, even when these agents are combined with a steroid. Cannabinoids are probably effective but produce frequent side effects.

\section{Authors' conclusions}

Our overall knowledge of the most effective antiemetics to prevent chemotherapy-induced nausea and vomiting in childhood is incomplete. Future research should be undertaken in consultation with children, young people, and families that have experienced chemotherapy and should make use of validated, age-appropriate measures. This review suggests that 5- $\mathrm{HT}_{3}$ antagonists are effective in patients who are to receive emetogenic chemotherapy, with granisetron or palonosetron possibly better than ondansetron. Adding dexamethasone improves control of vomiting, although the risk-benefit profile of adjunctive steroid remains uncertain.

\section{PLAIN LANGUAGE SUMMARY}

\section{Drugs to prevent nausea and vomiting in children and young people undergoing chemotherapy}

\section{Background}

The use of chemotherapy to treat cancer in children and young people can produce nausea (a sensation that one might vomit) and vomiting. These extremely unpleasant sensations continue to be a problem despite better antiemetic (antisickness) drugs.

\section{Review question}

How effective are medications to prevent nausea and vomiting in children and young people undergoing chemotherapy?

\section{Key results}

We found only 34 properly randomised trials that had been undertaken in children, which examined 26 drug combinations. Trials tended to report vomiting rather than nausea, even though nausea is generally a more distressing experience. We could make no firm conclusions about which drugs are best, what dose of drug is most effective, or whether it is better to receive treatments orally (by mouth) or intravenously (injected). It seems that the $5-\mathrm{HT}_{3}$ antagonists (the 'trons', for example ondansetron, granisetron, or tropisetron) are better than older agents, and that adding dexamethasone to these drugs makes them even more effective. Further research should consider what patients and families deem to be important, use established measures of nausea and vomiting, and attempt to use even newer techniques in the undertaking of reviews in order to maximise the information available. 


\section{B A C K G R O U N D}

Despite advances in antiemetic therapies, nausea and vomiting continue to be a problem for children undergoing treatment for malignancies (Holdsworth 2006), and are highly unpleasant (Dolgin 1989). The selection of an appropriate and effective antiemetic regimen has the potential to impact on quality of life by eradicating or reducing the symptom and its associated clinical problems. Due to limited studies in children, optimal paediatric dosing and scheduling of antiemetics remains uncertain (Antonarakis 2004a; Roila 2005). This results in inconsistencies and variation in prescribing, which is often underpinned by personal preference and experience, as opposed to research-based evidence (Foot 1994). In contrast, international evidence-based guidelines have been produced for adults (Kris 2005).

The development of 5- $\mathrm{HT}_{3}$ antagonists, such as ondansetron, and the wider use of corticosteroids have greatly improved the control and reduction of chemotherapy-associated nausea and vomiting (Culy 2001). However, the use of more intensive and emetogenic chemotherapeutic agents means that nausea and vomiting are still a major problem, and a significant number of children and young people continue to experience emesis (Holdsworth 2006). Efforts to reduce this side effect of treatment therefore must continue. In addition, these symptoms are frequently a feature of the palliative care phase and may have a detrimental effect on quality of life (Wolfe 2000).

Nausea and vomiting can have profound physical and psychological consequences. The physical consequences may include dehydration, electrolyte imbalance, anorexia, weight loss, weakness, increased susceptibility to infections, and disruption of normal childhood activities (Cotanch 1985). Chemotherapyinduced nausea and vomiting are considered to be among the most aversive of side effects, causing much distress to the child and family (Zeltzer 1991). When asked to identify what factors were distressing when receiving chemotherapy, parents of children and young people themselves reported physical concerns such as nausea and vomiting as being particularly problematic (Hedstrom 2003). Interventions that affect the physiological and psychological dimensions of nausea and vomiting, as well as those that reduce the number of episodes of emesis, are required to provide effective and holistic management for these distressing and debilitating symptoms.

There appear to be distinct clinical phases of nausea and vomiting related to chemotherapy. These commence with anticipatory nausea and vomiting, symptoms that precede the administration of chemotherapy, often following a previous aversive chemotherapy experience. Estimates of the prevalence of anticipatory nausea and vomiting have ranged from $20 \%$ to $30 \%$ (Dolgin 1985). This experience responds poorly to pharmacological approaches to antiemesis (Richardson 2007). Symptoms following administration of chemotherapy, and within 24 hours, are defined as acute nausea and vomiting. The incidence of this varies according to the emetogenicity of the chemotherapy received, but without prophylaxis it can be upwards of $90 \%$ for some commonly used agents (for example cisplatin) (Holdsworth 2006). Symptoms beyond 24 hours are described as delayed nausea and vomiting, and may occur in up to half of patients, usually after receiving platinum compounds or alkylating agents (Holdsworth 2006).
Different antiemetic agents have different modes of action, Antonarakis 2004b, and differing effectiveness (Antonarakis 2004a; Holdsworth 2006). Within a class of agents, varying side effects may alter the overall utility of a drug (Sandoval 1999). Different dose schedules and routes of administration have been used with the same agent with uncertain results (Sandoval 1999; White 2000).

In order to clearly define the limits of our knowledge of antiemetic medications, we undertook a systematic review of pharmacological approaches to prevent or reduce anticipatory, acute, and delayed symptoms of nausea and vomiting in children and young people who have cancer. This is an update of the original review published in 2010 (Phillips 2010).

\section{O B JECTIVES}

\section{Aim}

To assess the effectiveness and adverse events of pharmacological interventions in preventing nausea and vomiting in children and young people (aged less than 18 years) about to receive or receiving chemotherapy.

\section{Objectives}

- To assess the effectiveness of pharmacological interventions in controlling anticipatory nausea and vomiting in children and young people (aged less than 18 years) about to receive chemotherapy.

- To assess the effectiveness of pharmacological interventions in controlling acute and delayed nausea and vomiting in children and young people (aged less than 18 years) receiving chemotherapy.

- To determine the associated adverse events in participants receiving pharmacological antiemetics.

- To assess the effect that pharmacological antiemetics have on the quality of life of treated participants.

\section{METHODS}

\section{Criteria for considering studies for this review}

\section{Types of studies}

Randomised controlled trials (RCTs), where a pharmacological antiemetic, cannabinoid, or benzodiazepine has been compared with either placebo or an alternative active intervention.

\section{Types of participants}

Children and young people (less than 18 years) with a diagnosis of cancer who have received chemotherapy and pharmacological antiemetics.

\section{Types of interventions}

Standard pharmacological antiemetics used in the treatment of chemotherapy-induced nausea and vomiting. These include (but are not limited to):
- $5-\mathrm{HT}_{3}$ antagonists;
- benzodiazepines;
- cannabinoids;
- corticosteroids; 
- cyclizine;

- dopamine blockers; and

- levomepromazine.

We excluded NK1 antagonists, which are the subject of another Cochrane review (Tremont-Lukats 2007). We also excluded nonpharmacological approaches from this review.

This review addressed the effectiveness of each agent in the prevention and control of acute and delayed chemotherapyinduced nausea and vomiting compared to placebo or active comparators.

This review also sought to address the effectiveness of the following agents in the control of anticipatory nausea and vomiting compared to placebo or any active comparator:

- cannabinoids;

- benzodiazepines.

\section{Types of outcome measures}

1. Complete control of nausea (no nausea and no use of rescue medications) prior to chemotherapy delivery (anticipatory phase), in the acute phase (first 24 hours of treatment with chemotherapy), and in the delayed phase (after 24 hours of treatment with chemotherapy) of nausea and vomiting.

2. Complete control of vomiting (no vomiting and no use of rescue medications) prior to chemotherapy delivery (anticipatory phase), and in the acute and delayed phases of nausea and vomiting.

3. Adverse effects as defined by each trial found to be eligible for this review.

4. Quality-of-life measures.

Where data on the complete control of nausea and vomiting were absent, we estimated the effectiveness by analysis of the average difference using a continuous measure of vomiting (for example 'number of vomits per day') where available.

\section{Search methods for identification of studies}

\section{Electronic searches}

We undertook searches in the following databases in order to identify relevant studies. We have reported full details of the search strategies in Appendix 1.

- The Cochrane Central Register of Controlled Trials (CENTRAL) (Cochrane Library - http://www.thecochranelibrary.com/) from inception to 16 December 2014 (Issue 11, 2014).

- Ovid MEDLINE and Ovid MEDLINE In Process and Other NonIndexed Citations (Ovid Online - www.ovid.com) from 1966 to 16 December 2014.

- EMBASE (Ovid Online - www.ovid.com) from 1980 to 16 December 2014

- LILACS (Literatura Latino-Americana e do Caribe em Ciências da Saúde) (http://bases.bireme.br/cgi-bin/wxislind.exe/iah/ online/) from inception to 17 December 2014.

- PsycINFO (Ovid Online - www.ovid.com) from 1806 to 16 December 2014
We searched the following proceedings abstracts. We have reported full details of the search strategies in Appendix 2.

- American Society of Clinical Oncology (http://www.asco.org) from 2008 to 2014.

- International Society of Paediatric Oncology (SIOP) (http:// www.siop.nl/) from 2008 to 2014.

- Multinational Association of Supportive Care in Cancer (MASCC) (http://www.mascc.org/) from 2008 to 2014.

- ISI Science and Technology Proceedings (http:// wos.mimas.ac.uk/) from 2008 to 2014.

We also undertook searches for ongoing clinical trials using several Internet resources. We have reported full details of the search strategies in Appendix 3.

- International Cancer Research Portfolio (ICRP) (http:// www.cancerportfolio.org/) from inception to 16 December 2014.

- National Cancer Institute Clinical Trials PDQ (http:// www.cancer.gov/Search/SearchClinicalTrialsAdvanced.aspx) from inception to 16 December 2014.

- National Cancer Research Institute (NCRI) (http:// www.ncri.org.uk/) from inception to 16 December 2014.

- Current Controlled Trials (mRCT Register) (http:// www.isrctn.com/) from inception to 16 December 2014.

- CinicalTrials.gov (http://clinicaltrials.gov/) from inception to 16 December 2014.

- CenterWatch (http://www.centerwatch.com/) from inception to 16 December 2014.

\section{Terminology}

We identified the terms for the search strategies through discussion between an Information Specialist and the rest of the research team, by scanning the background literature, and by browsing the MEDLINE thesaurus (MeSH). The Cochrane Childhood Cancer Group also provided assistance. We searched all databases from their inception to the date of the search. Searches covered the inception of the database to 16 or 17 December 2014. We applied no language or other restrictions.

\section{Cochrane filters}

The Cochrane Childhood Cancer Group suggested several search filters for this review (Kremer 2014).

Study type: We used the sensitive trials filter developed by the Centre for Reviews and Dissemination in MEDLINE. A trials filter was developed for EMBASE based on the suggestions in the Cochrane Handbook for Systematic Reviews of Interventions. This was then adapted to run on PsycINFO. We did not use study type filters in the other databases.

Childhood: The Cochrane Childhood Cancer Group has a filter for children (age 0 to 18 years), which we used where appropriate (Kremer 2014).

Childhood cancer: Since we were using a filter for children, we adapted some aspects of the Cochrane Childhood Cancer Group filter to prevent duplication. For instance, 'childhood cancer' was replaced by 'cancer', since the concept of childhood was already expressed in the age facet. 


\section{Searching other resources}

We screened the references of any identified systematic reviews and initiated personal communication with the authors of relevant trials to request further information on published, unpublished, or ongoing studies. We also screened the reference lists of included studies. We employed no language restrictions.

\section{Data collection and analysis}

\section{Selection of studies}

After employing the search strategy, two review authors independently screened each abstract to identify studies meeting the inclusion criteria. Discrepancies were resolved by consensus without the need for final resolution using a third-party arbitrator. We obtained in full any study that seemed to meet the inclusion criteria on the grounds of the title, abstract, or both, for closer inspection and inclusion or exclusion.

\section{Data extraction and management}

Two review authors independently extracted outcome data from each included RCT in the following categories: participants, methods, interventions, and outcome measurements of interest. We recorded the outcome measurements as binary data (number of participants with total control of nausea and vomiting during the study period relative to the total number of participants evaluable for treatment) where possible. Discrepancies between review authors were resolved by consensus. We sought clarification from trial authors in cases of unclear or missing data.

\section{Assessment of risk of bias in included studies}

Two review authors independently extracted quality data from each included RCT according to the following criteria: concealment of treatment allocation, blinding of the care provider, blinding of the participants, blinding of the outcome assessor, random sequence generation, and incomplete outcome data. We partially assessed the potential for selective reporting of outcomes: we checked the reported outcomes against where the study methods stated which outcomes were collected. (In no cases did we check the trial reported against the previously or separately published trial protocol.) We also noted other potentials for bias. These were: publication bias; the funder of the study, and any explanation as to their role; and for cross-over studies the drop-out rates in each phase of the trial. For all quality items, we used the definitions as described in the module of the Cochrane Childhood Cancer Group (Kremer 2014). Discrepancies between review authors were resolved by consensus.

\section{Data synthesis}

When statistically appropriate, we combined the aggregate data to obtain a pooled effect size. We planned to assess for effects related to potential sources of bias, agent, dose, schedule, and route of administration.

We entered data into RevMan 5.3, RevMan 2014, and planned to undertake analyses according to the guidelines of the Cochrane
Handbook for Systematic Reviews of Interventions for eight separate primary outcomes (Higgins 2011):

- complete control of nausea before chemotherapy treatment (anticipatory nausea);

- complete control of vomiting before chemotherapy treatment (anticipatory vomiting);

- complete control of nausea up to 24 hours of chemotherapy treatment (acute nausea);

- complete control of nausea after 24 hours of chemotherapy treatment (delayed nausea);

- complete control of vomiting up to 24 hours of chemotherapy treatment (acute vomiting);

- complete control of vomiting after 24 hours of chemotherapy treatment (delayed vomiting);

- adverse event rate;

- quality-of-life measures.

Where appropriate, we examined outcomes when studies were grouped by class of agent, dose, schedule, and route of administration. Where data on the complete control of nausea and vomiting were absent, we estimated the effectiveness by analysis of the average difference using a continuous measure of vomiting (for example 'number of vomits per day'). Where possible, we used an intention-to-treat analysis. Where data were missing, we undertook an available case analysis (using all cases with available data as the denominator). As this did not affect any pooled analysis, we did not undertake a sensitivity analysis. To maximise the data from crossover studies, we used paired data where available. Where these were not available, we analysed studies as if they had a traditional parallel design without accounting for paired data. We calculated risk ratios and combined data using methods described by Zou 2007.

We explored heterogeneity narratively, looking at alternative populations, doses, and comparators. We compared randomeffects and fixed-effect models for pooled estimates when the calculated $\mathrm{I}^{2}$ value was greater than $50 \%$.

\section{RE S U L T S}

\section{Description of studies}

\section{Results of the search}

The original search identified a total of 844 potentially useful individual articles (see Figure 1 for details). We identified 67 articles for detailed screening. We identified one ongoing study (NCT00429702 2007), and could not retrieve three studies (Gómez 1995; Xu 1997; Zeng 1995). We attempted to contact authors to clarify aspects of study design, data analysis, and to retrieve specific data on those participants under 18 years of age. We identified 27 articles reporting on 28 trials for inclusion in the review. These included 1719 participants (median 30, range 12 to 428) and 2226 episodes (median 50.5, range 20 to 428). 
Figure 1. Flow diagram of study selection process original review (Phillips 2010).

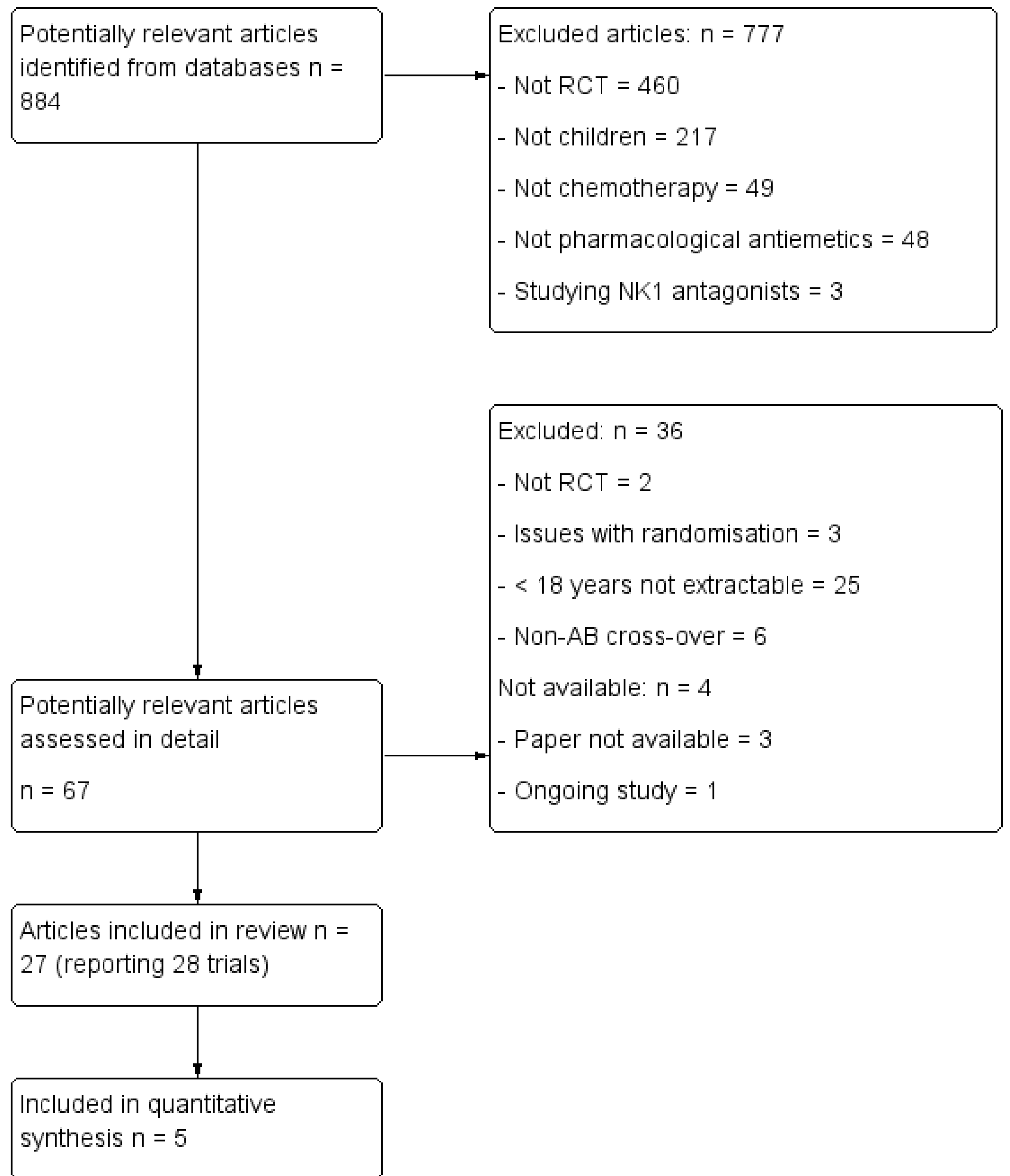

The updated search in December 2014 found a further 344 potentially useful individual articles (see Figure 2 for details). We identified 12 articles for detailed screening. The previously identified ongoing study had been terminated without publication of results and was thus added to the Characteristics of excluded studies table. We identified six new articles for inclusion in the review, and identified that the ongoing study (NCT00429702 2007) had been closed through poor accrual. The new studies included a further 304 participants and 869 episodes. 
Figure 2. Flow diagram of study selection process for additional studies identified in 2014 update.

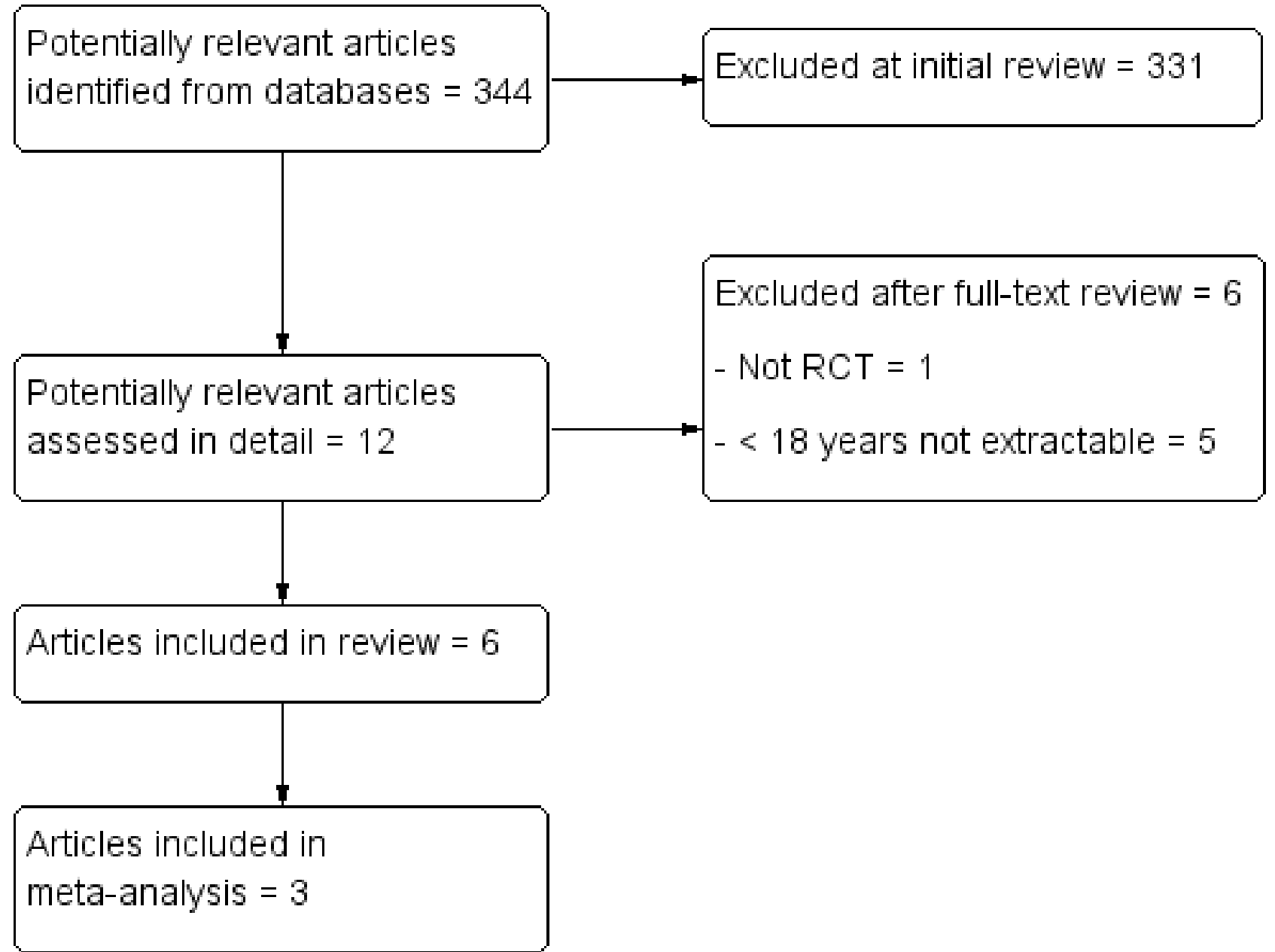

\section{Included studies}

The 34 included trials ( 28 from the original review and 6 from the update) examined a wide range of different pharmacological antiemetics, used different doses and comparators, and reported a variety of outcomes. With the exception of Parker 2001, who examined the use of ondansetron for intrathecal chemotherapy only, and Nagel 2008, who examined the use of ondansetron and fentanyl for intrathecal chemotherapy only, all trials looked at the effectiveness of treatments on systemic chemotherapy-induced nausea and vomiting.

Of the eight outcome measures specified in this review, no data were available from any study on anticipatory nausea or vomiting, or for any validated quality-of-life measures. No trials compared different durations of antiemetic medication.

Data on any outcomes beyond the first 24 hours of chemotherapy were infrequently reported (Berrak 2007; Brock 1996; Emir 2013; Noguera 2001; Sepulveda-Vildosola 2008; Siddique 2011).

Data on nausea were inconsistently reported using unvalidated measurement scales (see Characteristics of included studies for details). They were presented in thirteen trials (Brock 1996; Dalzell 1986; Ekert 1979; Ekert 1979a; Emir 2013; Mehta 1986; Nagel 2008; Noguera 2001; Orchard 1999; Sandoval 1999; Sepulveda-Vildosola
2008; Siddique 2011; Suarez 1994), with a further four studies detailing a compound outcome of nausea, vomiting, or both (Dick 1995; Mabro 2000; Sandoval 1999; Tejedor 1999).

The majority of quantitative data related to the complete control of acute vomiting (27 trials) (Alvarez 1995; Basade 1996; Berrak 2007; Brock 1996; Chan 1987; Dick 1995; Ekert 1979; Ekert 1979a; Emir 2013; Graham-Pole 1986; Hirota 1993; Jaing 2004; Komada 1999; Kurucu 2012; Mabro 2000; Marshall 1989; Mehta 1986; Nagel 2008; Noguera 2001; Orchard 1999; Parker 2001; Safonova 1999; Sandoval 1999; Sepulveda-Vildosola 2008; Shi 2012; Siddique 2011; Suarez 1994). Adverse events were reported in all except five studies (Kurucu 2012; Mehta 1986; Parker 2001; Shi 2012; Tsuchida 1999), and not separately reported for children in one study (Orchard 1999).

For three groups of studies, we undertook a pooled analysis. These were for the addition of dexamethasone to $5-\mathrm{HT}_{3}$ antagonists (Analysis 1.1), for different doses of granisetron (Analysis 2.1), and for ondansetron versus granisetron (Analysis 3.1 to Analysis 3.4). No other pooled analyses were possible (data for individual studies are presented in Analysis 4.1 to Analysis 4.5). The quality and quantity of included studies limited the exploration of heterogeneity. 


\section{Excluded studies}

We have included information on the 43 studies excluded at the detailed screening stage in the Characteristics of excluded studies table. The most common reason for exclusion was that information on participants less than 18 years old was unavailable. This was almost always a very small proportion of the study population.

\section{Risk of bias in included studies}

See the 'Risk of bias' section of the Characteristics of included studies table and Figure 3 for the exact scores and the support for the judgements made. 
Figure 3. Risk of bias summary: review authors' judgements about each risk of bias item for each included study.

\begin{tabular}{|c|c|c|c|c|c|c|c|c|}
\hline & 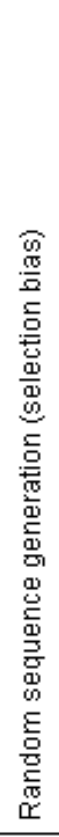 & 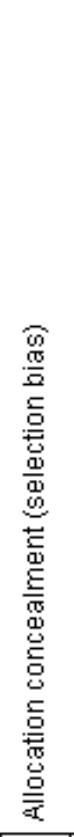 & 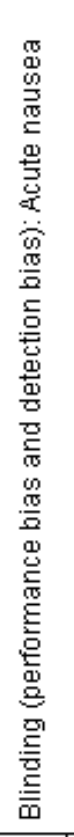 & 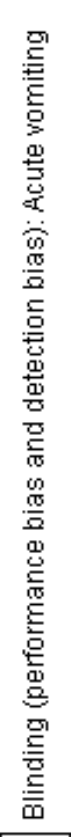 & 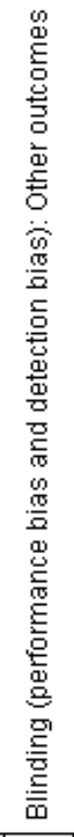 & 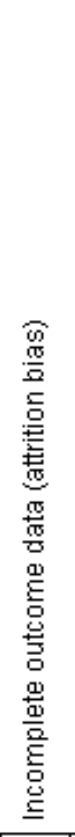 & 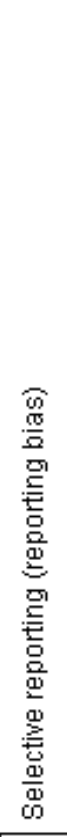 & 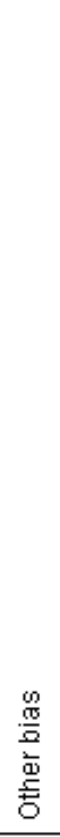 \\
\hline Alvarez 1995 & + & $?$ & + & + & $?$ & - & + & $?$ \\
\hline Basade 1996 & + & $?$ & $?$ & $?$ & $\odot$ & $\odot$ & + & + \\
\hline Berrak 2007 & + & + & 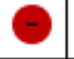 & + & + & + & + & + \\
\hline Brock 1996 & $?$ & $?$ & 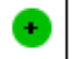 & + & 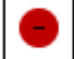 & 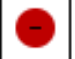 & + & $\odot$ \\
\hline Chan 1987 & $?$ & $?$ & $\Theta$ & $?$ & $\theta$ & + & + & + \\
\hline Dalzell 1986 & $?$ & $?$ & $\odot$ & $\theta$ & $?$ & 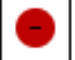 & + & $\odot$ \\
\hline Dick 1995 & $?$ & + & $\odot$ & $\theta$ & $\odot$ & + & + & $\odot$ \\
\hline Ekert 1979 & $?$ & $?$ & $?$ & $?$ & $\odot$ & + & + & $?$ \\
\hline Ekert 1979a & $?$ & $?$ & $?$ & $?$ & $?$ & + & + & + \\
\hline Emir 2013 & $?$ & $?$ & $?$ & $?$ & $?$ & + & + & $?$ \\
\hline Graham-Pole 1986 & + & + & $\Theta$ & - & + & 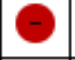 & + & $\odot$ \\
\hline Hahlen 1995 & 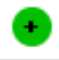 & $?$ & $?$ & $?$ & $?$ & $?$ & + & $?$ \\
\hline Hirota 1993 & $?$ & $?$ & $?$ & $?$ & $?$ & $\odot$ & + & $\oplus$ \\
\hline Jaing 2004 & $\Theta$ & $\theta$ & $\odot$ & 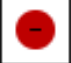 & - & + & + & + \\
\hline Komada 1999 & $?$ & $?$ & $\Theta$ & - & - & + & + & $\Theta$ \\
\hline Kurucu 2012 & $?$ & $?$ & $\odot$ & $O$ & 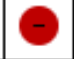 & + & + & + \\
\hline Mabro 2000 & $?$ & $?$ & $\odot$ & + & + & + & + & + \\
\hline Marshall 1989 & $?$ & $?$ & $?$ & $?$ & $?$ & $?$ & + & $?$ \\
\hline Mehta 1986 & $?$ & ? & + & $\odot$ & $\theta$ & 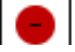 & + & + \\
\hline
\end{tabular}


Figure 3. (Continued)

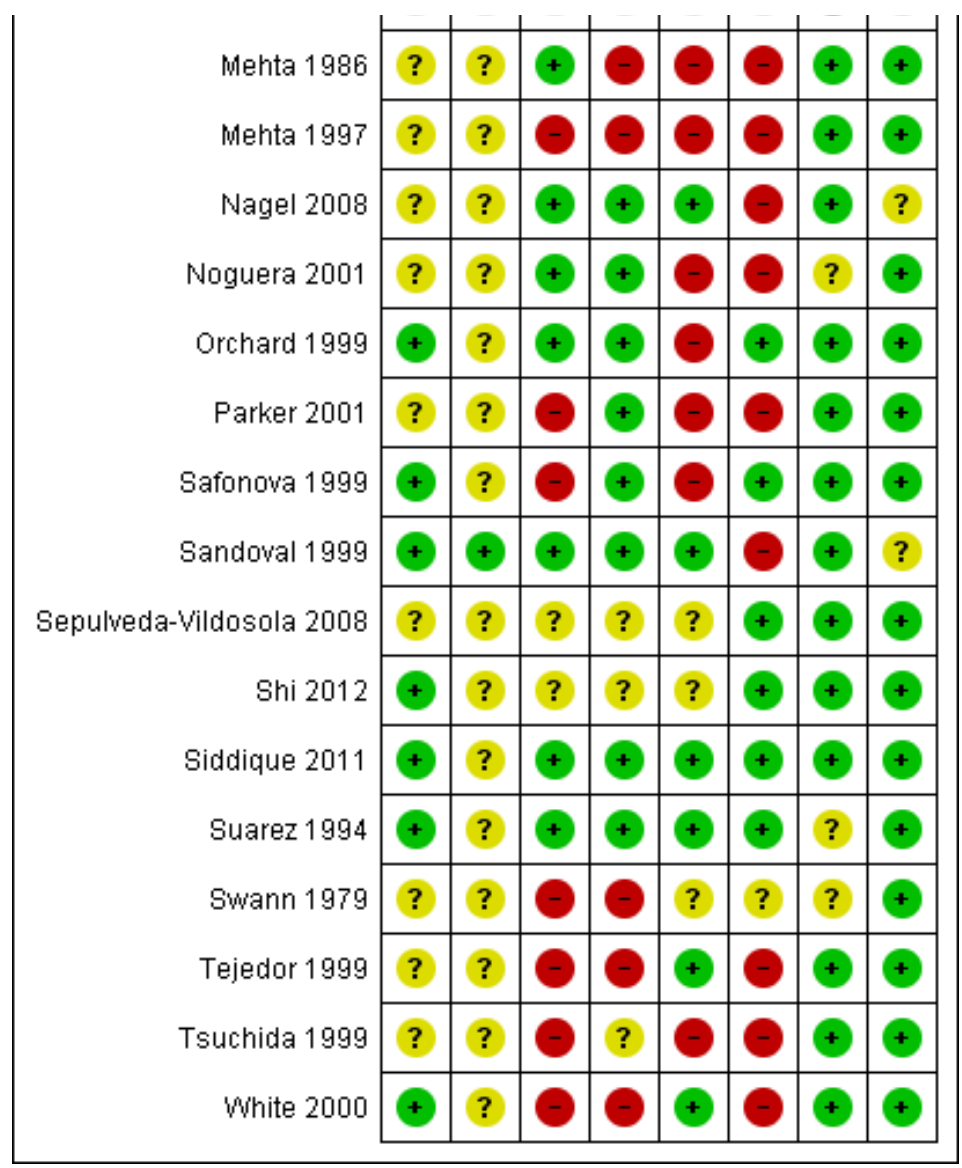

\section{Allocation}

Random sequence generation was adequate, using computergenerated number or random number tables, in 12 studies (Alvarez 1995; Basade 1996; Berrak 2007; Graham-Pole 1986; Hahlen 1995; Orchard 1999; Safonova 1999; Sandoval 1999; Shi 2012; Siddique 2011; Suarez 1994; White 2000), inadequate in one (Jaing 2004), and not clearly reported in the remaining 21 .

Allocation concealment was adequate in four studies (Berrak 2007; Dick 1995; Graham-Pole 1986; Sandoval 1999), inadequate in one (Jaing 2004), and not clearly reported in the other 29.

\section{Blinding}

Blinding was reported to have been undertaken in 14 studies (Alvarez 1995; Berrak 2007; Brock 1996; Graham-Pole 1986; Mabro 2000; Mehta 1986; Noguera 2001; Orchard 1999; Parker 2001; Safonova 1999; Sandoval 1999; Suarez 1994; Tejedor 1999; White 2000). It was unclear in 15 studies (Basade 1996; Chan 1987; Dalzell 1986; Ekert 1979; Ekert 1979a; Emir 2013; Hahlen 1995; Hirota 1993; Marshall 1989; Nagel 2008; Sepulveda-Vildosola 2008; Shi 2012; Siddique 2011; Swann 1979; Tsuchida 1999), with four of these uncertain because of the obvious and frequent side effects of cannabinoids (Chan 1987; Dalzell 1986; Ekert 1979; Ekert 1979a). Five studies were reported as not blinded (Dick 1995; Jaing 2004; Komada 1999; Kurucu 2012; Mehta 1997). No study reported any assessment of the quality of blinding. We have provided details of the study roles masked to the intervention in each outcome of each study in the Characteristics of included studies table.

It was possible to attempt to assess the effect of blinding in Analysis 1.1, where studies with unclear blinding, as compared to studies where there was convincing blinding, were associated with a reduced estimate of the benefit of additional steroid to $5-\mathrm{HT}_{3}$ antagonists, in contrast to Analysis 2.1, where increasing certainty in blinding was associated with a smaller benefit of higher-dose granisetron. These assessments were based on very small numbers of studies (Hirota 1993 and Alvarez 1995 in Analysis 1.1 and Komada 1999, Tsuchida 1999, and Mabro 2000 for Analysis 2.1) and alternative explanatory covariates, such as type of added steroid (in Analysis 1.1), the presence of paired data, and completeness of follow-up should also be assessed. In Analysis 3.1 to Analysis 3.4, the only adequately blinded study, Noguera 2001, favoured granisetron for some outcomes and ondansetron for others.

\section{Incomplete outcome data}

In 16 studies (Berrak 2007; Chan 1987; Dick 1995; Ekert 1979; Ekert 1979a; Emir 2013; Jaing 2004; Komada 1999; Kurucu 2012; Mabro 2000; Orchard 1999; Safonova 1999; Sandoval 1999; SepulvedaVildosola 2008; Shi 2012; Siddique 2011), there were no dropouts or failures to complete cross-over. In three studies, uncertainty remained about the proportion of incomplete data (Hahlen 1995; Marshall 1989; Swann 1979). In the remaining 15 studies, the proportion of missing data ranged from 2.9\%, in Basade 1996, to 50\%, in Tejedor 1999. 
No study obviously analysed participants according to the treatment they had received rather than that to which they had been randomised.

\section{Selective reporting}

We did not note selective reporting of particular outcomes within trials in this review, although in three studies there was inadequate detail to fully assess this (Noguera 2001; Suarez 1994; Swann 1979). It should be noted that this assessment was limited to the reporting of methods and results within the published paper, and in no cases referenced to a previously published protocol.

\section{Other potential sources of bias}

Two cross-over studies provided paired data (Hirota 1993; Jaing 2004). The remaining cross-over studies did not (Alvarez 1995; Basade 1996; Berrak 2007; Chan 1987; Dalzell 1986; Ekert 1979; Emir 2013; Mabro 2000; Marshall 1989; Nagel 2008; Parker 2001; Swann 1979; Tsuchida 1999), and were often unclear about when dropouts occurred, with the potential for unequal drop-out influencing the results of these studies.

The approach of using cross-over data in this review is supported by empirical evidence of a lack of 'cross-over' effects from Tsuchida 1999 (treatment effect $P=0.18$, period effect $P=0.76$, carry-over $P$ $=0.38)$.

Given so few comparable studies (Peters 2008), we could not reasonably assess publication bias in this review. A relatively small number of as-yet-unidentified studies could alter the results of this review significantly. The lack of comparable studies also hampered any assessment of the effect of study funding source.

\section{Effects of interventions}

The detailed results of this review can be seen in the control of acute and delayed nausea (Analysis 4.1 and Analysis 4.2), acute and delayed emesis (Analysis 4.2 and Analysis 4.3), and combined outcomes (Analysis 4.4 and Analysis 4.5). As discussed previously, the majority of results in this review related to the control of acute emesis. Description of the effects of interventions separated by age group, tumour type, or chemotherapy received was not possible.

\section{Benzodiazepines}

One study used a combination 'cocktail' of antiemetics that included benzodiazepines: lorazepam, dexamethasone, metoclopramide, and benztropine (Marshall 1989). A further study looked at another 'cocktail' including benzodiazepines: granisetron, dexamethasone, midazolam, and diphenhydramine (Emir 2013). These are reported in the 'Other agents' section below.

\section{Cannabinoids}

Four studies compared cannabinoids with alternative antiemetics (Chan 1987; Dalzell 1986; Ekert 1979; Ekert 1979a). They demonstrate markedly different results: the Ekert studies show benefit of tetrahydrocannabinol over prochlorperazine and metoclopramide in controlling nausea as well as vomiting. For example, for tetrahydrocannabinol versus prochlorperazine, complete control of acute nausea: risk ratio (RR) 20.7; 95\% confidence interval $(\mathrm{Cl}) 17.2$ to 36.2 , and for complete control of vomiting: RR 19.0; $95 \% \mathrm{Cl} 13.7$ to 26.3. Dalzell 1986 showed an improvement with nabilone over domperidone in the reduction of nausea (nausea severity score 1.5 compared with $2.5, P=0.01$ (Wilcoxon signed-rank) on scale of 0 (none) to 3 (worst)). Chan 1987, the largest and most recent study, demonstrated no benefit of tetrahydrocannabinol over prochlorperazine in the control of emesis (complete control of vomiting RR 1.0; 95\% Cl 0.85 to 1.17). The heterogeneity of studies meant no outcomes could be pooled.

\section{Corticosteroids}

Two studies examined steroids as a sole antiemetic agent. Basade 1996 looked at the comparative effectiveness of $8 \mathrm{mg} /$ $\mathrm{m}^{2}$ dexamethasone to $1.5 \mathrm{mg} / \mathrm{kg}$ metoclopramide, and found dexamethasone to be significantly better (complete control of vomiting: RR 2.10; $95 \% \mathrm{Cl} 1.77$ to 2.50 ). Mehta 1986 compared 4 $\mathrm{mg} / \mathrm{kg}$ of methylprednisolone to $0.5 \mathrm{mg} / \mathrm{kg}$ of chlorpromazine and found no evidence of a difference (complete control of vomiting: RR $1.0 ; 95 \% \mathrm{Cl} 0.54$ to 1.86 ).

Two studies examined the use of additive steroids combined with 5- $\mathrm{HT}_{3}$ antagonists (Alvarez 1995; Hirota 1993), which are pooled in Analysis 1.1 and demonstrate good benefit. There was moderate heterogeneity between these two studies $\left(I^{2}=56 \%\right)$, with the methylprednisolone study, Hirota 1993, having a lower estimate of additional benefit compared with the added dexamethasone study, Alvarez 1995. The fixed-effect and random-effects models gave qualitatively similar results, with the expected increase in uncertainty with the random-effects model and a relatively greater weighting given to the smaller study (fixed-effect complete control of vomiting: RR $2.10 ; 95 \% \mathrm{Cl} 1.62$ to 2.72 , random-effects complete control of vomiting: RR $2.03 ; 95 \% \mathrm{Cl} 1.35$ to 3.04 ).

The use of steroids with non-5- $\mathrm{HT}_{3}$ antagonists compared with 5$\mathrm{HT}_{3}$ antagonists is reviewed below.

No trials directly compared different types of steroid, dosing, schedules, or routes of administration. Dexamethasone is the steroid most frequently studied.

\section{5-HT 3 antagonists}

\section{Class}

We found no direct comparisons of a single $5-\mathrm{HT}_{3}$ antagonists against single non-5- $\mathrm{HT}_{3}$ antagonists. Three studies examined the effectiveness of $5-\mathrm{HT}_{3}$ antagonists compared to concurrent dexamethasone and either metoclopramide, in Dick 1995, or chlorpromazine, in Hahlen 1995 and Tejedor 1999. Dick 1995 found ondansetron to be more effective than traditional antiemetics (complete control of nausea and vomiting: RR 3.67; 95\% Cl 2.25 to 5.98). Hahlen 1995 showed granisetron to be more effective (median number of vomiting episodes 1.5 on ondansetron, 7 on chlorpromazine/dexamethasone), but using a different outcome measure. Tejedor 1999 showed the chlorpromazine/ dexamethasone combination to be equally effective (complete control of vomiting: RR $1.03 ; 95 \% \mathrm{Cl} 0.79$ to 1.35 ). Nagel 2008 examined the use of ondansetron, fentanyl, or placebo (4way randomisation) after general anaesthesia and intrathecal methotrexate, and showed a reduction in the number of vomit/ retch episodes with ondansetron (from 2 to 0.5 mean vomits in the 24 hours after the procedure, $\mathrm{P}<0.001$ ) 


\section{Drugs}

Five studies undertook direct comparisons of different $5-\mathrm{HT}_{3}$ antagonists: Noguera 2001 examined ondansetron, granisetron, and tropisetron; Orchard 1999 compared granisetron and ondansetron (both with dexamethasone); Jaing 2004 compared different doses of granisetron and ondansetron (without dexamethasone); Siddique 2011 also compared ondansetron with granisetron; and Sepulveda-Vildosola 2008 compared ondansetron with palonosetron.

The results of the three studies comparing ondansetron with granisetron are pooled in Analysis 3.1 to Analysis 3.4. We found no difference between the agents at preventing acute or delayed nausea or delayed vomiting, however granisetron was significantly better than ondansetron at preventing acute vomiting (RR 2.26; $95 \% \mathrm{Cl} 2.04$ to 2.51 ). We could not include the results of Orchard 1999 due to marked differences in the way efficacy was reported.

Sepulveda-Vildosola 2008 found a significant reduction in vomiting on days 1 to $3(P=0.010,0.023$, and 0.028 , respectively) and nausea in days 1 to 4 ( $P=0.001,0.000,0.000$, and 0.002 , respectively) in children given palonosetron rather than ondansetron.

For the effect of additive dexamethasone, see above.

\section{Dose and schedule}

Seven studies undertook dose comparisons of $5-\mathrm{HT}_{3}$ antagonists. Four studies compared granisetron doses. Berrak 2007 compared $10 \mathrm{mcg} / \mathrm{kg}$ with $40 \mathrm{mcg} / \mathrm{kg}$. Their published results demonstrated no significant difference between the doses (complete control of acute vomiting: RR $0.88 ; 95 \% \mathrm{Cl} 0.70$ to 1.10 ). The other three studies, Komada 1999, Mabro 2000, and Tsuchida 1999, compared granisetron $20 \mathrm{mcg} / \mathrm{kg}$ with $40 \mathrm{mcg} / \mathrm{kg}$ and were pooled in Analysis 2.1. This demonstrated no clear difference in the doses (complete control of vomiting: RR $0.93 ; 95 \% \mathrm{Cl} 0.80$ to 1.07 ), with very little heterogeneity $\left(I^{2}=0 \%\right)$.

Two studies compared ondansetron doses. Brock 1996 compared loading with $5 \mathrm{mg} / \mathrm{m}^{2}$ and $10 \mathrm{mg} / \mathrm{m}^{2}$, finding no advantage to the higher dose (complete control of vomiting: RR $0.89 ; 95 \% \mathrm{Cl}$ 0.72 to 1.10 , complete control of nausea: RR $1.01 ; 95 \% \mathrm{Cl} 0.81$ to 1.25). Sandoval 1999 examined the effect of giving a single high dose of $0.6 \mathrm{mg} / \mathrm{kg}$ ondansetron compared with dividing the dose into four $0.15 \mathrm{mg} / \mathrm{kg}$ aliquots over 16 hours and found no clear difference (complete control of vomiting: RR $0.94 ; 95 \% \mathrm{Cl} 0.49$ to 1.79 , complete control of nausea: RR $1.25 ; 95 \% \mathrm{Cl} 0.70$ to 2.23 ).

Tropisetron doses are compared in a single dose-finding study (Suarez 1994), which showed that doses of $0.1 \mathrm{mg} / \mathrm{kg}$ or greater were more effective than placebo in controlling acute nausea and vomiting.

\section{Route}

Only one uncompromised randomised study compared different routes of administration of $5-\mathrm{HT}_{3}$ antagonists. Safonova 1999 demonstrated that $8 \mathrm{mg}$ oral ondansetron was equivalent to $5 \mathrm{mg} /$ $\mathrm{m}^{2}$ when combined with intravenous dexamethasone (complete control of vomiting: RR $1.04 ; 95 \% \mathrm{Cl} 0.62$ to 1.75 ).

\section{Other agents}

Seven further studies examined the role of chlorpromazine (Graham-Pole 1986; Marshall 1989), metoclopramide (GrahamPole 1986; Swann 1979), the combination 'cocktail' of lorazepam, dexamethasone, metoclopramide, and benztropine (LDMB) (Marshall 1989), the combination 'cocktail' of granisetron, dexamethasone, midazolam, and diphenhydramine (GDMD) (Emir 2013), hewei zhiou recipe (traditional Chinese herbal medicine) (Shi 2012), hydroxyzine (Kurucu 2012), and fentanyl (Nagel 2008).

Graham-Pole 1986 demonstrated that chlorpromazine $0.5 \mathrm{mg} /$ $\mathrm{kg}$ was more effective than a similar dose of metoclopramide (reported as mean number of vomits 1.8 (standard deviation (SD) 2.3) compared with 3.5 (SD 4.1) in 24 hours; duration of nausea reduced to 4.2 hours (SD 6.4 hours) compared with 9.0 hours (SD 9.7 hours). Swann 1979 showed domperidone (up to $1 \mathrm{mg} / \mathrm{kg}$ ) was also more effective than metoclopramide $0.5 \mathrm{mg} / \mathrm{kg}$ (median number of vomits in 36 hours was 1 , compared with 4; median duration of 0.5 hours versus 4.5 hours). Marshall 1989 showed an improvement for the LDMB cocktail over $0.325 \mathrm{mg} / \mathrm{kg}$ chlorpromazine (complete control of vomiting: RR $2.40 ; 95 \% \mathrm{Cl} 1.76$ to 3.27 ). Emir 2013 showed slight superiority of the GDMD cocktail compared with ondansetron and dexamethasone in controlling acute vomiting, but this did not reach statistical significance. There was no difference between the GDMD cocktail compared with ondansetron and dexamethasone in controlling delayed vomiting. Shi 2012 showed less severe vomiting in participants given hewei zhiou recipe in addition to ondansetron compared to those given ondansetron alone (vomiting $Z$ scores: $-2.966,-3.256,-3.453,-4.870,-3.627$ for treatment cycles 2 to $6, P<$ $0.01)$, although this effect was not seen in the first treatment cycle (vomiting Z score -0.470, P > 0.05). Kurucu 2012 found complete control of vomiting in $56 \%$ of participants given hydroxyzine in addition to ondansetron, compared to $22 \%$ of participants given ondansetron alone $(P=0.006)$. Nagel 2008 found no effect of adding fentanyl $(0.1 \mathrm{mg} / \mathrm{kg})$ to ondansetron $(0.15 \mathrm{mg} / \mathrm{kg})$ on nausea or vomiting after general anaesthesia and intrathecal methotrexate.

\section{Adverse events}

The reporting of adverse events varied markedly across different studies, making any pooling of the results inappropriate. The comparison of proportions across different studies and drugs as an indirect assessment of relative harms is unlikely to be valid, as different measures and methods of reporting were used. We have reported the results narratively below.

\section{5-HT $T_{3}$ antagonists}

A wide range of adverse events were noted for $5-\mathrm{HT}_{3}$ antagonists. Those reported in more than one study included:

- headache (10 studies; range from 2\% in White 2000 to $53 \%$ in Mehta 1997);

- sedation/somnolence (five studies; range from $2 \%$ in Mabro 2000 to $66 \%$ in Mehta 1997);

- abdominal pain (six studies; range from $8 \%$ in White 2000 to $20 \%$ in Siddique 2011);

- dizziness/vertigo (three studies; $1 \%$ in Brock 1996, 2\% in Tejedor 1999, and 4\% in Suarez 1994);

- diarrhoea (four studies; $2 \%$ in White 2000, 4\% in Suarez 1994, $17 \%$ in Alvarez 1995, and 20\% in Siddique 2011); 
- constipation (four studies; proportion not noted in Jaing 2004, $5 \%$ in Tejedor 1999, 6\% in Mabro 2000, 16.7\% (ondansetron) and $13.3 \%$ (granisetron) in Siddique 2011);

- fever (three studies; 3\% in White 2000, 4\% in Suarez 1994, and $17 \%$ in Hahlen 1995);

- leg or muscle pains (two studies; 4\% in Suarez 1994 and 6\% in Dick 1995); and

- hypertension (two studies; 2\% in Tejedor 1999 and 4\% in Suarez 1994).

Five studies reported that no adverse events occurred (Berrak 2007; Hirota 1993; Komada 1999; Safonova 1999; Sepulveda-Vildosola 2008). No clear dose-related or specific drug-related effects were noted. For details see Table 1.

\section{Cannabinoids}

Of the three studies that examined cannabinoids, the main side effects noted were:

- drowsiness (three studies; $80 \%$ in Chan 1987, 67\% in Dalzell 1986, and 28\% in Ekert 1979);

- dizziness (two studies; 60\% in Chan 1987 and 44\% in Dalzell 1986);

- mood alteration (three studies; 17\% in Chan 1987 and Dalzell 1986 and 5\% in Ekert 1979); and

- increased appetite (two studies; 3\% in Chan 1987 and 5\% in Dalzell 1986).

Isolated reports included ocular problems, orthostatic hypotension, muscle twitching, pruritis, vagueness, hallucinations, lightheadedness, and dry mouth. For details see Table 2.

As no study compared different cannabinoids, any differences in side effects noted may be due to the study design or rigour of data collection rather than different drugs or dosing schedules used.

\section{Steroids}

The adverse effects of steroids as an antiemetic are difficult to assess in the studies undertaken. Only Basade 1996 reported the adverse effects of dexamethasone; any adverse effects additional to those from ondansetron were not reported in the study by Alvarez 1995, and no adverse events at all were noted in the studies of Hirota 1993 and Safonova 1999. Further studies using steroids are contaminated by the co-administration of chlorpromazine (Hahlen 1995; Tejedor 1999), metoclopramide (Dick 1995), or as part of the LDMB cocktail (Marshall 1989). For details see Table 1 and Table 3.

\section{Metoclopramide}

Four studies that reported adverse events assessed metoclopramide. These included:

- dystonia/extrapyramidal effects (two studies; $20 \%$ in GrahamPole 1986 and 2\% in Basade 1996);

- drowsiness (two studies; approximately 8\% in Ekert 1979 and Graham-Pole 1986).

Other effects were only noted in one of the studies, and included depression, anorexia, abdominal pain, and headache. One study (Swann 1979) reported no adverse events at all. For details see Table 2 and Table 3.

\section{Chlorpromazine}

Two studies assessed chlorpromazine and found diarrhoea (12\% in Marshall 1989), extrapyramidal effects (4\%) and drowsiness (52\%) (in Graham-Pole 1986). For details see Table 3.

\section{Other agents}

One study assessed midazolam and diphenhydramine and found constipation (6.5\%), sedation (12.9\%), and hypotension (6.5\%) (Emir 2013).

\section{DISCUSSION}

This update of our systematic review of antiemetic medication for prophylaxis and treatment of chemotherapy-induced nausea and vomiting in children and young adults found only 34 randomised controlled trials, examining 28 different pairs of combinations of antiemetic medication approaches. This adds just three studies to the original review of 2010. The quality of individual studies remains moderate, with relatively small numbers and wide confidence intervals limiting our ability to draw conclusions. The lack of adequate numbers of studies undertaking similar comparisons limits any interpretation of the threats to randomisation that were identified. The outcomes reported were largely related to emesis, rather than the more patient-relevant and often more distressing experience of nausea. Where nausea was reported, it was done without the use of validated symptom scales. Nausea, assessed through self report, is particularly difficult and complex to assess. Children, certainly the very young, may not have the language skills to describe their experience, or understand what they are being asked to describe, and this may in part explain the focus on vomiting. Direct comparisons of different agents and classes of agents were generally lacking: granisetron may help with acute vomiting (but not nausea, or delayed vomiting or nausea) more than ondansetron. A single study suggests palonesotron may be better than ondansetron. When we sought information to assess the risk-benefit balance, by addressing reporting of adverse events, this was still extremely variable. Our search strategy was extensive and we attempted through contact with authors to extract any useful data from studies with primarily adult participants. We sought, found, and included trials published in the Japanese, Latin American, and non-English language European literature in order to reduce the possibility of language-related publication bias (Egger 1997; Juni 2002; Moher 2003).

Four years on from our original review, our overall picture of which are the most effective antiemetics to prevent chemotherapyinduced nausea and vomiting in childhood remains incomplete and imprecise.

What can we conclude from such sparse data? We continue to propose tentative clinical implications and restate our firm research questions.

The practical, clinical conclusions from these trials are that $5-\mathrm{HT}_{3}$ antagonists seem more effective than older antiemetic agents, even when those agents are combined with a steroid. Of the $5-\mathrm{HT}_{3}$ receptor antagonists, granisetron may be more effective at higher doses, and granisetron and palonosetron may be more effective than ondansetron, though the small quantity of evidence cautions against firm conclusions. The addition of dexamethasone to the 5$\mathrm{HT}_{3}$ antagonist of choice doubles the chance of complete control 
of acute vomiting. The use of steroids as an antiemetic, despite evidence of efficacy, remains controversial. The lowest effective dose is unclear. Pre-clinical studies suggest that glucocorticoids reduce sensitivity of a wide range of cell lines to chemotherapy agents (Meyer 2006; Zhang 2006). However, no clinical studies have found an association between steroids as an antiemetic and worsened outcomes. Cannabinoids are probably effective, but produce high levels of side effects, which may be experienced as adverse by some patients, but not by others. We cannot clearly define a route, schedule, or dose of maximal efficiency of any antiemetic medication from this review.

A further issue is the duration of the antiemesis, particularly with respect to multi-day/multi-agent chemotherapy (Einhorn 2005; Roila 2005). Although the available evidence deals with antiemetic therapy given alongside chemotherapy, the optimal duration of antiemesis following the last dose of chemotherapy is unclear. In various studies, antiemesis is reported as being given during chemotherapy (for example Alvarez 1995), or for up to two (for example White 2000) to three (for example Brock 1996) days following the last administration of emetogenic chemotherapy. There appear to be no randomised trials that address this issue, and in this respect the duration of chemotherapy antiemesis is unclear and should be a subject of further investigation, particularly by way of randomised controlled trials.

The research questions that emerge concern the need for good primary research: the conduct of new paediatric symptom control studies and the use of basic pharmacological and pharmacogenetic studies to support our understanding of the drugs' use. They also raise questions about the methods used in Cochrane systematic reviews, namely the need to explore alternative approaches in order to incorporate data from adult studies and also maximise the use of data from existing studies.

It is acknowledged that studies in children for drugs that have a feasible use in this age group are an ethical imperative, WHO 2007, and increasingly have a financial benefit, Sammons 2009. Such studies should use appropriate doses as assisted by both adult and pharmacokinetic studies, and patient-important valid outcomes. In this setting, the complete control of nausea has been shown to be most important, with young people distinguishing between nausea and vomiting when selecting the five most important symptoms to feature on an electronic questionnaire (Gibson 2007). Nausea is consistently mentioned as a frequent distressing problem by children and young people, with vomiting described as relatively less distressing (Hedstrom 2003; Williams 2006), and to some vomiting may be a relief from nausea. Despite the availability of validated instruments to measure nausea in children (Dupuis 2006; Linder 2005), these did not feature in the papers reviewed. Where nausea was assessed, see for example Berrak 2007, no validated instrument was used. Rather, participants between one and 23 years old recorded a combined assessment of nausea, retching, and vomiting in a diary, which failed to reveal the intensity of nausea as distinct. Future research would benefit from the use of validated instruments that capture both patient and caregiver perceptions if we are really to understand the cancer care experience (Dodd 2001; Hinds 2008).

This review has very few trials from which to assess the effects of publication bias, or make firm conclusions. As such, it is relatively 'unstable', as a few further trials addressing one specific issue may tip the clinical conclusion in an alternative direction. The interventions for which meta-analysis was possible have weaknesses. The meta-analysis assessing the effectiveness of additional steroid has only two studies and moderate heterogeneity. The use of a random-effects model assumes a difference (heterogeneity) in the underlying populations or interventions, and undertaking such an analysis with few (less than five) studies has been questioned (Higgins 2009). The heterogeneity may come from the use of different steroids, and this would be supported by the findings of Basade 1996 and Mehta 1986, whose studies, if read simplistically, show that dexamethasone is a better antiemetic than methylprednisolone. However, their comparator agents (metoclopramide and chlorpromazine, respectively) are not shown to be equal in the study by Graham-Pole 1986. Analysis with simple binary meta-analysis cannot hope to address these problems. The studies also have a different reported quality of blinding. In the meta-analysis of different doses of granisetron (Analysis 2.1), there are three different strengths of certainty about the blinding applied to outcome measurement in the studies, and the results follow the expected pattern of having greater observed benefit for the unblinded study. This may mean that the estimate is an exaggeration. The meta-analytic comparison of granisetron and ondansetron for control of acute vomiting only included three studies, and was driven very strongly by the smallest study, which showed different results than the other two.

Alternative approaches to maximising data from existing studies using network meta-analysis in order to develop robust indirect comparisons remain a developing field of inquiry (Sutton 2008). Such network meta-analyses have provided useful answers to unsolved questions in adult cardiology (Caldwell 2005), neurology (Wilby 2005), and mental health (Cipriani 2009). An extension of this technique, using adult studies as an explicit starting point from which to assess the studies in children, is worth examining to answer this question and to provide a clear and potential methodological base from which to examine other symptom control questions in paediatric oncology, but it has not yet been taken up and developed.

Our conclusions remain fundamentally unchanged from 2010: the key research questions that require new evidence should be decided in consultation with children, young people, and families that have undergone chemotherapy and been exposed to the medications and their effects. It has been acknowledged there may be a mismatch between available research evidence and the research preferences of consumers (Glass 2002; Tallon 2000), and across a range of services and clinical care, there is an expectation of increased and more meaningful consumer participation and involvement, including children (Coyne 2006; Darbyshire 2005). As clinicians, we suggest that three key points may be: to clarify further whether there are any patient-important differences in the $5-\mathrm{HT}_{3}$ antagonists; to understand the most beneficial dose and duration of dexamethasone; and to clarify the role of new agents (for example substance $P$ antagonists) in the prevention of chemotherapy-induced nausea.

The prevention and treatment of nausea, and to a lesser extent vomiting, caused by chemotherapy in children and young people remains an important issue for their quality of life. Continued research into improving our understanding of and refining our therapies is required. Until then, the results of this review suggest that $5-\mathrm{HT}_{3}$ antagonists with dexamethasone added are effective in patients who are to receive highly emetogenic chemotherapy, 
although the exact risk-benefit profile of the addition of steroid remains uncertain.

\section{AUTHORS' CONCLUSIONS}

\section{Implications for practice}

Our overall picture of which antiemetics are the most effective in preventing chemotherapy-induced nausea and vomiting in childhood remains incomplete and imprecise. With this caveat, we suggest that $5-\mathrm{HT}_{3}$ antagonists with dexamethasone added are effective in patients who are to receive highly emetogenic chemotherapy, although it remains uncertain how the proven benefit of steroid in reducing emesis balances with the in vitro reduction in chemotherapy sensitivity.

\section{Implications for research}

Children and young people rate therapy-related symptoms as the overall most difficult aspect of cancer treatment (Moody 2006; Woodgate 2003; Woodgate 2005). Traditionally, symptom management has emphasised medical management with administration of pharmacologic agents. More recently, a holistic approach to symptom management has been recommended, which includes both pharmacological and non-pharmacological interventions (Rheingans 2008). We would recommend this approach to care and hence advocate that the key questions that require new evidence should be decided in consultation with children, young people, and families that have undergone chemotherapy and been exposed to the medications and their effects. Symptom experiences are a family affair, as symptoms are multifaceted and reciprocal, impacting the whole family and its overall quality of life (Woodgate 2003). We would recommend that any new research questions should take into consideration multidimensional approaches to the symptom experience of children and young people.

As clinicians, we suggest that three key points are still likely to be to:

1. clarify potential patient-important differences between the 5$\mathrm{HT}_{3}$ antagonists;
2. understand the most beneficial dose and duration of dexamethasone; and

3. clarify the role of new agents (e.g. substance P antagonists) in the prevention of chemotherapy-induced nausea.

We would recommend that any future research make use of validated, age-appropriate measures. Additionally, future research would benefit from the use of validated instruments that capture both patient and caregiver perceptions if we are really to understand the cancer care experience (Hinds 2008).

The role of newer techniques of meta-analysis in paediatrics, which incorporate Bayesian approaches, is as yet uncertain and is a pressing area for further methodological research that may produce significant clinical benefits.

\section{ACKNOWLEDGEMENTS}

This work is undertaken under the direction of the Children's Cancer and Leukaemia Group/Paediatric Oncology Nursing Forum Supportive Care Group, but is the responsibility of the authors.

The authors would like to acknowledge the contributions of the translators (Prof David Reeves, Dr Moyacr Nobre, Tiago Fonseca, and Koji Kawahara) for their time and help; the staff at the Centre for Reviews and Dissemination (University of York, UK) for their advice and support; and the Trials Search Co-ordinator of the Cochrane Childhood Cancer Group and the peer reviewers whose comments have improved this paper. Kate Light was a coauthor of the protocol and the review, and we thank her for her valuable input. We also wish to acknowledge the particular assistance of Dr Aksoylar, Dr Berrak, Dr Jaing, and Dr Orchard for their provision of extra data from their studies.

RSP was funded by a Clinical Research Fellowship from Candlelighters: The Yorkshire Children's Cancer Charity. The editorial base of the Cochrane Childhood Cancer Group is funded by Kinderen Kankervrij (KIKA). 


\section{R E F E R E N C E S}

\section{References to studies included in this review}

Alvarez 1995 \{published data only\}

Alvarez O, Freeman A, Bedros A, Call SK, Volsch J, Kalbermatter $\mathrm{O}$, et al. Randomized double-blind crossover ondansetron-dexamethasone versus ondansetron-placebo study for the treatment of chemotherapy-induced nausea and vomiting in pediatric patients with malignancies. Journal of Pediatric Hematology/Oncology 1995;17(2):145-50.

\section{Basade 1996 \{published data only\}}

Basade M, Kulkarni SS, Dhar AK, Sastry PS, Saikia B, Advani SH. Comparison of dexamethasone and metoclopramide as antiemetics in children receiving cancer chemotherapy. Indian Pediatrics 1996;33(4):321-3.

\section{Berrak 2007 \{published data only (unpublished sought but not} used)\}

Berrak SG, Ozdemir N, Bakirci N, Turkkan E, Canpolat C Beker B, et al. A double-blind, crossover, randomized dosecomparison trial of granisetron for the prevention of acute and delayed nausea and emesis in children receiving moderately emetogenic carboplatin-based chemotherapy. Supportive Care in Cancer 2007;15(10):1163-8.

\section{Brock 1996 \{published data only\}}

Brock P, Brichard B, Rechnitzer C, Langeveld NE, Lanning M, Soderhall $S$, et al. An increased loading dose of ondansetron: a north European, double-blind randomised study in children, comparing $5 \mathrm{mg} / \mathrm{m} 2$ with $10 \mathrm{mg} / \mathrm{m} 2$. European Journal of Cancer 1996;32A(10):1744-8.

\section{Chan 1987 \{published data only\}}

Chan HS, Correia JA, MacLeod SM. Nabilone versus prochlorperazine for control of cancer chemotherapy-induced emesis in children: a double-blind, crossover trial. Pediatrics 1987;79(6):946-52.

\section{Dalzell 1986 \{published data only\}}

Dalzell AM, Bartlett H, Lilleyman JS. Nabilone: an alternative antiemetic for cancer chemotherapy. Archives of Disease in Childhood 1986;61(5):502-5.

\section{Dick 1995 \{published data only\}}

Dick GS, Meller ST, Pinkerton CR. Randomised comparison of ondansetron and metoclopramide plus dexamethasone for chemotherapy induced emesis. Archives of Disease in Childhood 1995;73(3):243-5.

\section{Ekert 1979 \{published data only\}}

Ekert H, Waters KD, Jurk IH, Mobilia J, Loughnan P. Amelioration of cancer chemotherapy-induced nausea and vomiting by delta-9-tetrahydrocannabinol. Medical Journal of Australia 1979;2:657-9.

\section{Ekert 1979a \{published data only\}}

* Ekert H, Waters KD, Jurk IH, Mobilia J, Loughnan P. Amelioration of cancer chemotherapy-induced nausea and vomiting by delta-9-tetrahydrocannabinol. Medical Journal of Australia 1979;2(12):657-9.

\section{Emir 2013 \{published data only\}}

Emir S, Erturgut P, Vidinlisan S. Comparison of granisetron plus dexamethasone versus an antiemetic cocktail containing midazolam and diphenhydramine for chemotherapy induced nausea and vomiting in children. Indian Journal of Medical and Paediatric Oncology 2013;34(4):270-3.

\section{Graham-Pole 1986 \{published data only\}}

Graham-Pole J, Weare J, Engel S, Gardner R, Mehta P, Gross S. Antiemetics in children receiving cancer chemotherapy: a double-blind prospective randomized study comparing metoclopramide with chlorpromazine. Journal of Clinical Oncology 1986;4(7):1110-3.

Hahlen 1995 \{published data only\}

Hahlen K, Quintana E, Pinkerton CR, Cedar E. A randomized comparison of intravenously administered granisetron versus chlorpromazine plus dexamethasone in the prevention of ifosfamide-induced emesis in children. Journal of Pediatrics 1995;126(2):309-13.

\section{Hirota 1993 \{published data only\}}

Hirota T, Honjo T, Kuroda R, Saeki K, Katano N, Sakakibara Y, et al. Antiemetic efficacy of granisetron in pediatric cancer treatment - (2). Comparison of granisetron and granisetron plus methylprednisolone as antiemetic prophylaxis. Gan to Kagaku Ryoho [Japanese Journal of Cancer \& Chemotherapy] 1993;20(15):2369-73.

\section{Jaing 2004 \{published and unpublished data\}}

Jaing T-H, Tsay P-K, Hung I-J, Yang C-P, Hu W-Y. Singledose oral granisetron versus multidose intravenous ondansetron for moderately emetogenic cyclophosphamidebased chemotherapy in pediatric outpatients with acute lymphoblastic leukemia. Pediatric Hematology \& Oncology 2004;21(3):227-35

\section{Komada 1999 \{published data only\}}

Komada Y, Matsuyama T, Takao A, Hongo T, Nishimura Y, Horibe $\mathrm{K}$, et al. A randomised dose-comparison trial of granisetron in preventing emesis in children with leukaemia receiving emetogenic chemotherapy. European Journal of Cancer 1999;35(7):1095-101.

\section{Kurucu 2012 \{published data only\}}

Kurucu N, Durmaz M. Effect of hydroxyzine in controlling acute chemotherapy-induced vomiting in children: a randomised trial. UHOD - Uluslararasi Hematoloji-Onkoloji Dergisi 2012;22(2):99-106.

\section{Mabro 2000 \{published data only\}}

Mabro M, Cohn R, Zanesco L, Madon E, Hahlen K, Margueritte G, et al. Oral granisetron solution as prophylaxis for chemotherapy-induced emesis in children: double-blind study of 2 doses. Bulletin du Cancer 2000;87(3):259-64. 


\section{Marshall 1989 \{published data only\}}

Marshall G, Kerr S, Vowels M, O'Gorman-Hughes D, White L. Antiemetic therapy for chemotherapy-induced vomiting: metoclopramide, benztropine, dexamethasone, and lorazepam regimen compared with chlorpromazine alone. Journal of Pediatrics 1989;115(1):156-60.

\section{Mehta 1986 \{published data only\}}

Mehta P, Gross S, Graham-Pole J, Gardner R.

Methylprednisolone for chemotherapy-induced emesis: a double-blind randomized trial in children. Journal of Pediatrics 1986;108(5 Pt 1):774-6.

\section{Mehta 1997 \{published data only\}}

Mehta NH, Reed CM, Kuhlman C, Weinstein HJ, Parsons SK. Controlling conditioning-related emesis in children undergoing bone marrow transplantation. Oncology Nursing Forum 1997;24(9):1539-44.

\section{Nagel 2008 \{published data only\}}

Nagel K, Willan AR, Lappan J, Korz L, Buckley N, Barr RD. Pediatric Oncology Sedation Trial (POST): a double-blind randomized study. Pediatric Blood and Cancer 2008;51:634-8.

\section{Noguera 2001 \{published data only\}}

* Noguera D, Gómez R, Marcano A. 5-hydroxytriptamine type 3 receptor antagonists in the prevention of vomiting by cytostatics drugs in children [Antagonistas de receptores 5-hidroxitriptamina tipo 3 en la prevención de emesis por citostáticos en niños]. Salus Militiae 2001;26(1):71-6.

\section{Orchard 1999 \{published data only (unpublished sought but not} used)\}

Orchard PJ, Rogosheske J, Burns L, Rydholm N, Larson H, DeFor TE, et al. A prospective randomized trial of the antiemetic efficacy of ondansetron and granisetron during bone marrow transplantation. Biology of Blood \& Marrow Transplantation 1999;5(6):386-93.

\section{Parker 2001 \{published data only\}}

Parker RI, Prakash D, Mahan RA, Giugliano DM, Atlas MP. Randomized, double-blind, crossover, placebo-controlled trial of intravenous ondansetron for the prevention of intrathecal chemotherapy-induced vomiting in children. Journal of Pediatric Hematology/Oncology 2001;23(9):578-81.

\section{Safonova 1999 \{published data only\}}

Safonova SA, Gershanovich ML, Punanov luA, Kolygin BA. Evaluation of the anti-emetic effectiveness of two drug formulations of ondansetron in combined chemotherapy for children with malignant tumors. Voprosy Onkologii 1999;45(4):424-8.

\section{Sandoval 1999 \{published data only\}}

Sandoval C, Corbi D, Strobino B, Ozkaynak MF, Tugal O, Jayabose S. Randomized double-blind comparison of single high-dose ondansetron and multiple standard-dose ondansetron in chemotherapy-naive pediatric oncology patients. Cancer Investigation 1999;17(5):309-13.

\section{Sepulveda-Vildosola 2008 \{published data only\}}

Sepulveda-Vildosola AC, Betanzos-Cabrera Y, Lastiri GG, RiveraMarquez H, Villasis-Keever MA, del Angel VW, et al. Palonosetron hydrochloride is an effective and safe option to prevent chemotherapy-induced nausea and vomiting in children. Archives of Medical Research 2008;39:601-6.

\section{Shi 2012 \{published data only\}}

Shi X, Liu ZM, Zhu XD. Treatment of vomiting in children patients with solid tumor by hewei zhiou recipe combined ondansetron hydrochloride. Chinese Journal of Integrated Traditional and Western Medicine 2012;32(4):468-70.

\section{Siddique 2011 \{published data only\}}

Siddique R, Hafiz MG, Rokeya B, Jamal CY, Islam A. Ondansetron versus granisetron in the prevention of chemotherapy induced nausea and vomiting in children with acute lymphoblastic leukaemia. Mymensingh Medical Journal 2011;20(4):680-8.

\section{Suarez 1994 \{published data only\}}

Suarez A, Stettler ER, Rey E, Pons G, Simonetta-Chateauneuf C, de Bruijn KM, et al. Safety, tolerability, efficacy and plasma concentrations of tropisetron after administration at five dose levels to children receiving cancer chemotherapy. European Journal of Cancer 1994;30A(10):1436-41.

\section{Swann 1979 \{published data only\}}

Swann IL, Thompson EN, Qureshi K. Domperidone or metoclopramide in preventing chemotherapeutically induced nausea and vomiting. British Medical Journal 1979;2(6199):1188.

\section{Tejedor 1999 \{published data only\}}

Tejedor I, Idoate A, Jimenez M, Sierrasesumaga L, Giraldez J. Cost-effectiveness analysis of tropisetron vs. chlorpromazinedexamethasone in the control of acute emesis induced by highly emetogenic chemotherapy in children. Pharmacy World \& Science 1999;21(2):60-8.

\section{Tsuchida 1999 \{published data only\}}

Tsuchida Y, Hayashi Y, Asami K, Yamamoto K, Yokoyama J, Mugishima $\mathrm{H}$, et al. Effects of granisetron in children undergoing high-dose chemotherapy: a multi-institutional, cross-over study. International Journal of Oncology 1999;14(4):673-9.

\section{White 2000 \{published data only\}}

White L, Daly SA, McKenna CJ, Zhestkova N, Leal C, Breatnach F, et al. A comparison of oral ondansetron syrup or intravenous ondansetron loading dose regimens given in combination with dexamethasone for the prevention of nausea and emesis in pediatric and adolescent patients receiving moderately/highly emetogenic chemotherapy. Pediatric Hematology \& Oncology 2000;17(6):445-55

\section{References to studies excluded from this review}

\section{Aksoylar 2001 \{published and unpublished data\}}

Aksoylar S, Akman SA, Ozgenc F, Kansoy S. Comparison of tropisetron and granisetron in the control of nausea and vomiting in children receiving combined cancer chemotherapy. Pediatric Hematology \& Oncology 2001;18(6):397-406. 
Alavi 1985 \{published data only\}

Alavi JB, Torri S, Glover D, Hurwitz S, Glick JH. High-dose oral metoclopramide. An effective antiemetic agent. American Journal of Clinical Oncology 1985;8(3):260-5.

\section{Basch 2011 \{published data only\}}

* Basch E, Hesketh PJ, Kris MG, Prestrud AA, Temin S, Lyman GH. Antiemetics: American Society of Clinical Oncology clinical practice guideline update. Journal of Oncology Practice 2011;7(6):395-7.

\section{Bauduer 1999 \{published data only\}}

Bauduer F, Coiffier B, Desablens B. Granisetron plus or minus alprazolam for emesis prevention in chemotherapy of lymphomas: a randomized multicenter trial. Granisetron Trialists Group. Leukemia \& Lymphoma 1999;34(3-4):341-7.

\section{Bonaventura 1999 \{published data only\}}

Bonaventura A, Freeman S, Stewart J, Ackland S, Hall K, Gebski V. Control of acute and delayed vomiting with lorazepam, dexamethasone and metochlopramide (LDM) versus dexamethasone and ondansetron (DO) following highly emetogenic chemotherapy (meeting abstract). ASCO Conference Abstracts. Chicago: ASCO, 1999:2299.

\section{Brice 1989 \{published data only\}}

Brice P, Fiere D, Gastaut JL, Simon-Lejeune C, Carcassonne Y, Tredaniel J, et al. Comparison of the antiemetic effectiveness of high-dose corticosteroids with synacthene in nausea induced by chemotherapy: results of a randomized study. Bulletin $d u$ Cancer 1989;76(6):637-42.

\section{Corapcioglu 2005 \{published data only\}}

Corapcioglu F, Sarper N. A prospective randomized trial of the antiemetic efficacy and cost-effectiveness of intravenous and orally disintegrating tablet of ondansetron in children with cancer. Pediatric Hematology and Oncology 2005;22(2):103-14.

\section{Dana 1987 \{published data only\}}

Dana BW, McDermott M, Everts E, Abdulhay G. A randomized trial of high-dose bolus metoclopramide versus low-dose continuous infusion metoclopramide in the prevention of cisplatin-induced emesis. American Journal of Clinical Oncology 1987;10(3):253-6.

\section{Delgado 1983 \{published data only\}}

Delgado G, Stefanuto W, Novo NF. Preconous toxicity syndrome due to cancer chemotherapy: therapeutic effects of metoclopramide and corticosteroids compared with placebo [Síndrome da toxidade precoce induzida pela quimioterapia antineoplásica: efeito terapêutico de metoclopramida e corticosteróide versus placebo e proposta de um modelo patogênico]. Acta Oncologica (Brasil) 1983;3(1/3):19-29.

\section{Fauser 1998 \{published data only\}}

Fauser A, Pizzocaro G, Schuller G, Khayat D, Wilkinson P. A double-blind parallel study of intravenous (IV) dolasetron + dexamethasone vs. iv dolasetron alone in preventing fractionated cisplatin emesis (meeting abstract). ASCO Conference Abstracts. Chicago: ASCO, 1998:abstract 223.
Feng 2000 \{published data only\}

Feng FY, Zhang P, He YJ, Li YH, Zhou MZ, Cheng G, et al. Comparison of the selective serotonin antagonists ramosetron and granisetron in treating acute chemotherapy-induced emesis, nausea, and anorexia: a single-blind, randomized, crossover study. Current Therapeutic Research - Clinical and Experimental 2000;61(12):901-9.

\section{Feng 2002 \{published data only\}}

Feng FY, Zhang P, He YJ, Li YH, Zhou MZ, Cheng G, et al. Oral formulations of the selective serotonin antagonists ramosetron (intraoral disintegrator formulation) and granisetron hydrochloride (standard tablet) in treating acute chemotherapy-induced emesis, nausea, and anorexia: a multicenter, randomized, single-blind, crossover, comparison study. Current Therapeutic Research - Clinical and Experimental 2002;63(11):725-35.

\section{Forni $\mathbf{2 0 0 0}$ \{published data only\}}

Forni C, Ferrari S, Loro L, Mazzei T, Beghelli C, Biolchini A, et al. Granisetron, tropisetron, and ondansetron in the prevention of acute emesis induced by a combination of cisplatin-adriamycin and by high-dose ifosfamide delivered in multiple-day continuous infusions. Supportive Care in Cancer 2000;8(2):131-3.

\section{Friedman 2000 \{published data only\}}

Friedman CJ, Burris HA, Yocom K, Blackburn LM, Gruben D. Oral granisetron for the prevention of acute late onset nausea and vomiting in patients treated with moderately emetogenic chemotherapy. Oncologist 2000;5(2):136-43.

\section{Gagen 1984 \{published data only\}}

Gagen M, Gochnour D, Young D, Gaginella T, Neidhart J. A randomized trial of metoclopramide and a combination of dexamethasone and lorazepam for prevention of chemotherapy-induced vomiting. Journal of Clinical Oncology 1984;2(6):696-701.

\section{Gez 1989 \{published data only\}}

Gez E, Ben-Yosef R, Catane R, Brufman G, Biran S. Chlorpromazine and dexamethasone versus high-dose metoclopramide and dexamethasone in patients receiving cancer chemotherapy, particularly cis-platinum: a prospective randomized crossover study. Oncology 1989;46(3):150-4.

\section{Gorena 1996 \{published data only\}}

Gorena M, Giacaman A, Pastor P. Antiemetic therapy in testis cancer chemotherapy: comparison in cross-over study of ondansetron and metoclopramide [Terapia antiemética en quimioterapia por cáncer testicular: comparación en estudio cross-over de ondansetron y metoclopramida]. Revista Chile Urologica 1996;61(1):72-4.

\section{Hatae 1989 \{published data only\}}

Hatae Y, Takeda T, Nakadate H, Hatayama Y, Kishino T, Ogawa Y. The antiemetic effect and clinical evaluation of metoclopramide alone and combined with betamethasone in children with malignant tumor. Gan to Kagaku Ryoho [Japanese Journal of Cancer \& Chemotherapy] 1989;16(11):3639-42. 


\section{Herrstedt 2007 \{published data only\}}

Herrstedt J, Sigsgaard TC, Nielsen HA, Handberg J, Langer SW, Ottesen S, et al. Randomized, double-blind trial comparing the antiemetic effect of tropisetron plus metopimazine with tropisetron plus placebo in patients receiving multiple cycles of multiple-day cisplatin-based chemotherapy. Supportive Care in Cancer 2007;15(4):417-26.

\section{Hirota 1993a \{published data only\}}

Hirota T, Honjo T, Kuroda R, Saeki K, Katano N, Sakakibara Y, et al. Antiemetic efficacy of granisetron in the treatment of pediatric cancer - (1). Clinical evaluation of granisetron at a dose of 40 micrograms $/ \mathrm{kg}$. Gan to Kagaku Ryoho [Japanese Journal of Cancer \& Chemotherapy] 1993;20(14):2201-5.

\section{Jara 1999 \{published data only\}}

Jara C, Hernandez M, Alonso C, Fernandez A, GamezAldarava JL, Mayordomo JI. Dexamethasone with oral granisetron or metoclopramide in preventing chemotherapyinduced delayed emesis. A randomized, double-blind trial (meeting abstract). ASCO Conference Abstracts. Chicago: ASCO, 1999:abstract 2289.

\section{Joss 1994 \{published data only\}}

Joss RA, Bacchi M, Buser K, Kirchner V, Neuenschwander H, Orth $\mathrm{B}$, et al. Ondansetron plus dexamethasone is superior to ondansetron alone in the prevention of emesis in chemotherapy-naive and previously treated patients. Swiss Group for Clinical Cancer Research (SAKK). Annals of Oncology 1994;5(3):253-8.

\section{Kearsley 1989 \{published data only\}}

Kearsley JH, Williams AM, Fiumara AM. Antiemetic superiority of lorazepam over oxazepam and methylprednisolone as premedicants for patients receiving cisplatin-containing chemotherapy. Cancer 1989;64(8):1595-9.

\section{Keyhanian 2009 \{published data only\}}

Keyhanian S, Taziki O, Saravi MM, Fotokian Z. A randomized comparison of granisetron plus dexamethason with granisetron alone for the control of acute chemotherapy-induced emesis and nausea. International Journal of Hematology-Oncology and Stem Cell Research 2009;3(2):27-30.

\section{Koseoglu 1998 \{published data only\}}

Koseoglu V, Kurekci AE, Sarici U, Atay AA, Ozcan O. Comparison of the efficacy and side-effects of ondansetron and metoclopramide-diphenhydramine administered to control nausea and vomiting in children treated with antineoplastic chemotherapy: a prospective randomized study. European Journal of Pediatrics 1998;157(10):806-10.

\section{Luisi 2006 \{published data only\}}

Luisi FAV, Petrilli AS, Tanaka C, Caran EMM. Contribution to the treatment of nausea and emesis induced by chemotherapy in children and adolescents with osteosarcoma. Sao Paulo Medical Journal 2006;124(2):61-5.

\section{Matsuoka 2003 \{published data only\}}

Matsuoka S, Okamoto S, Watanabe R, Mori T, Nagayama H, Hamano Y, et al. Granisetron plus dexamethasone versus granisetron alone in the prevention of vomiting induced by conditioning for stem cell transplantation: a prospective randomized study. International Journal of Hematology 2003;77(1):86-90.

\section{Nathan 2006 \{published data only\}}

Nathan PC, Tomlinson G, Dupuis LL, Greenberg ML, Ota S, Bartels $U$, et al. A pilot study of ondansetron plus metopimazine vs. ondansetron monotherapy in children receiving highly emetogenic chemotherapy: a Bayesian randomized serial N-of-1 trials design. Supportive Care in Cancer 2006;14(3):268-76.

\section{NCT00429702 2007 \{published data only\}}

NCT00429702. Diphenhydramine, lorazepam, and dexamethasone in treating nausea and vomiting caused by chemotherapy in young patients with newly diagnosed cancer. clinicaltrials.gov/show/NCT00429702 (accessed 15 May 2010).

\section{Needles 1999 \{published data only\}}

Needles B, Miranda E, Garcia Rodriguez FM, Diaz LB, Spector J, Craig J, et al. A multicenter, double-blind, randomized comparison of oral ondansetron $8 \mathrm{mg}$ b.i.d., $24 \mathrm{mg}$ q.d., and 32 $\mathrm{mg}$ q.d. in the prevention of nausea and vomiting associated with highly emetogenic chemotherapy. S3AA3012 Study Group. Supportive Care in Cancer 1999;7(5):347-53.

\section{Onat 1995 \{published data only\}}

Onat H, Inanc SE, Saip P, Topuz E. Tropisetron (TRP) in the prevention of emesis associated with 5-day cisplatin-based chemotherapy (CT) in patients (pts) with germ cell tumors (Meeting abstract). ASCO Conference Abstracts. Chicago: ASCO, 1995:abstract 1760.

\section{Pillai 2011 \{published data only\}}

Pillai AK, Sharma KK, Gupta YK, Bakshi S. Anti-emetic effect of ginger powder versus placebo as an add-on therapy in children and young adults receiving high emetogenic chemotherapy. Pediatric Blood and Cancer 2011;56:234-8.

Relling 1993 \{published data only\}

Relling MV, Mulhern RK, Fairclough D, Baker D, Pui CH. Chlorpromazine with and without lorazepam as antiemetic therapy in children receiving uniform chemotherapy. Journal of Pediatrics 1993;123(5):811-6.

Roila 1995 \{published data only\}

Roila F, De Angelis V, Cognetti F, Ricci S, Contu A, Nuzzo A, et al. Ondansetron vs granisetron, both combined with dexamethasone in the prevention of cisplatin-induced emesis (Meeting abstract). ASCO Conference Abstracts. Chicago: ASCO, 1995:abstract 1721.

\section{Roila 1996 \{published data only\}}

Roila F, De Angelis V, Contu A, Scagliotti G, Tateo S, Massidda B, et al. Ondansetron (OND) vs metoclopramide (MTC) both combined with dexamethasone (DEX) in the prevention of cisplatin (CDDP)-induced delayed emesis (Meeting abstract). ASCO Conference Abstracts. Chicago: ASCO, 1996:abstract 1705. 
Roila 1998 \{published data only\}

Roila F, Ballatori E, Contu A, Tateo S, Ricci S, Ionta MT, et al. Optimal dose of intravenous dexamethasone in the prevention of cisplatin-induced acute emesis: a double blind randomized study. (Meeting abstract). ASCO Conference Abstracts. Chicago: ASCO, 1998:abstract 195.

\section{Roila 2000 \{published data only\}}

Roila F, Ballatori E, Bosnjak S, Fava S, Nuzzo A, Contu A, et al. Dexamethasone (DEX) alone or combined with ondansetron (OND) in the prevention of delayed emesis induced by moderately emetogenic chemotherapy (MEC). Proceedings of the American Society of Clinical Oncology 2000;19:(abstr 2358).

\section{Stiakaki 1999 \{published data only\}}

Stiakaki E, Savvas S, Lydaki E, Bolonaki I, Kouvidi E, Dimitriou H et al. Ondansetron and tropisetron in the control of nausea and vomiting in children receiving combined cancer chemotherapy. Pediatric Hematology \& Oncology 1999;16(2):101-8.

\section{Sumer 1988 \{published data only\}}

Sumer T, Abu-Melha A, Maqbool G, Al-Mulhim I. Dexamethasone as an antiemetic in children receiving cis-platinum. American Journal of Pediatric Hematology/Oncology 1988;10(2):126-8.

\section{Tian 2011 \{published data only\}}

Tian W, Wang Z, Zhou J, Zhang S, Wang J, Chen Q, et al. Randomized, double-blind, crossover study of palonosetron compared with granisetron for the prevention of chemotherapy-induced nausea and vomiting in a Chinese population. Medical Oncology 2011;28:71-8.

\section{Tsukuda 2009 \{published data only\}}

Tsukuda M, Ishitoya J, Mikami Y, Matsuda H, Katori H, Horiuchi $\mathrm{C}$, et al. Antiemetic effects of granisetron and dexamethasone combination therapy during cisplatincontaining chemotherapy for head and neck cancer: dexamethasone dosage verification trial. International Journal of Clinical Oncology 2009;14:337-43.

\section{Yalcin 1999 \{published data only\}}

Yalcin S, Tekuzman G, Baltali E, Ozisik Y, Barista I. Serotonin receptor antagonists in prophylaxis of acute and delayed emesis induced by moderately emetogenic, single-day chemotherapy: a randomized study. American Journal of Clinical Oncology: Cancer Clinical Trials 1999;22(1):94-6.

\section{Yonemura 2009 \{published data only\}}

Yonemura M, Katsumata N, Hashimoto H, Satake S, Kaneko M, Kobayashi Y, et al. Randomized controlled study comparing two doses of intravenous granisetron ( 1 and $3 \mathrm{mg}$ ) for acute chemotherapy-induced nausea and vomiting in cancer patients: a non-inferiority trial. Japanese Journal of Clinical Oncology 2009;39(7):443-8.

\section{References to studies awaiting assessment}

\section{Gómez 1995 \{published data only\}}

Gómez MH, Mas LL, Vallejos SC. Tropisetron with dexamethasone in the control of nausea and vomiting in emetogenic chemotherapy [Tropisetron mas dexametasona en el control de náuseas y vómitos en pacientes con quimioterapia emetizante]. Acta Cancerologica 1995;25(2):55-60.

\section{Xu 1997 \{published data only\}}

Xu B, Zhou J, Zhou A. Phase III clinical studies with ondansetron (Qilu) in the prophylaxis of nausea and vomiting induced by cisplatin. Chung-Hua Chung Liu Tsa Chih [Chinese Journal of Oncology] 1997;19(5):358-61.

Zeng 1995 \{published data only\}

Zeng W, Zhou J, Zhang P. The role of ondansetron (Qilu) in the prevention of non-cisplatin-induced vomiting - a randomized clinical trial. Chung-Hua Chung Liu Tsa Chih [Chinese Journal of Oncology] 1995;17(4):294-7.

\section{Additional references}

\section{Antonarakis 2004a}

Antonarakis ES, Evans JL, Heard GF, Noonan LM, Pizer BL, Hain RDW. Prophylaxis of acute chemotherapy-induced nausea and vomiting in children with cancer: what is the evidence?. Pediatric Blood and Cancer 2004;43(6):651-8.

\section{Antonarakis 2004b}

Antonarakis ES, Hain RDW. Nausea and vomiting associated with cancer chemotherapy: drug management in theory and in practice. Archives of Disease in Childhood 2004;89(9):877-80.

\section{Caldwell 2005}

Caldwell DM, Ades AE, Higgins JPT. Simultaneous comparison of multiple treatments: combining direct and indirect evidence. BMJ 2005;331(7521):897-900.

\section{Cipriani 2009}

Cipriani A, Furukawa TA, Salanti G, Geddes JR, Higgins JPT, Churchill R, et al. Comparative efficacy and acceptability of 12 new-generation antidepressants: a multiple-treatments metaanalysis. The Lancet 2009;373(9665):746-58.

\section{Cotanch 1985}

Cotanch P, Hockenberry M, Herman S. Self-hypnosis as antiemetic therapy in children receiving chemotherapy. Oncology Nursing Forum 1985;12(4):41-6.

\section{Coyne 2006}

Coyne I. Children's experiences of hospitalization. Journal of Child Health Care: For Professionals Working with Children in the Hospital and Community 2006;10(4):326-36.

\section{Culy 2001}

Culy CR, Bhana N, Plosker GL. Ondansetron: a review of its use as an antiemetic in children. Paediatric Drugs 2001;3(6):441-79.

\section{Darbyshire 2005}

Darbyshire P, MacDougall C, Schiller W. Multiple methods in qualitative research with children: more insight or just more?. Qualitative Research 2005;5(4):417-36. 


\section{Dodd 2001}

Dodd M, Janson S, Facione N, Faucett J, Froelicher ES, Humphreys J, et al. Advancing the science of symptom management. Journal of Advanced Nursing 2001;33(5):668-76.

\section{Dolgin 1985}

Dolgin MJ, Katz ER, McGinty K, Siegel SE. Anticipatory nausea and vomiting in pediatric cancer patients. Pediatrics 1985;75(3):547-52.

\section{Dolgin 1989}

Dolgin MJ, Katz ER, Zeltzer LK, Landsverk J. Behavioral distress in pediatric patients with cancer receiving chemotherapy. Pediatrics 1989;84(1):103-10.

\section{Dupuis 2006}

Dupuis LL, Taddio A, Kerr EN, Kelly A, MacKeigan L. Development and validation of the pediatric nausea assessment tool for use in children receiving antineoplastic agents. Pharmacotherapy 2006;26(9):1221-31.

\section{Egger 1997}

Egger M, Zellweger-Zohner T, Schneider M, Junker C, Lengeler $\mathrm{C}$, Antes $\mathrm{G}$. Language bias in randomised controlled trials published in English and German. The Lancet 1997;350(9074):326-9.

\section{Einhorn 2005}

Einhorn LH, Rapoport B, Koeller J, Grunberg SM, Feyer P, Rittenberg $\mathrm{C}$, et al. Antiemetic therapy for multiple-day chemotherapy and high-dose chemotherapy with stem cell transplant: review and consensus statement. Supportive Care in Cancer 2005;13(2):112-6.

\section{Foot 1994}

Foot AB, Hayes C. Audit of guidelines for effective control of chemotherapy and radiotherapy induced emesis. Archives of Disease in Childhood 1994;71(5):475-80.

\section{Gibson 2007}

Gibson F, Aldiss S, Kearney N, Miller M, Maguire R, McCann L, et al. An evaluation of an advanced symptom management system (ASyMS (C)) to monitor and manage chemotherapy related toxicity with young people. Centre for Research Nursing and Allied Health Professions, Great Ormond Street Hospital for Children and Cancer Care. London, 2007.

\section{Glass 2002}

Glass N. UK charity to involve public in decision making for cancer research priorities. The Lancet 2002;360(9344):1487.

\section{Hedstrom 2003}

Hedstrom M, Haglund K, Skolin I, von Essen L. Distressing events for children and adolescents with cancer: child, parent, and nurse perceptions. Journal of Pediatric Oncology Nursing 2003;20(3):120-32.

\section{Higgins 2009}

Higgins JPT, Thompson SG, Spiegelhalter DJ. A re-evaluation of random-effects meta-analysis. Journal of the Royal Statistical Society. Series A (Statistics in Society) 2009;172(1):137-59.

\section{Higgins 2011}

Higgins JPT, Green S (editors). Cochrane Handbook for Systematic Reviews of Interventions Version 5.1.0 [updated March 2011]. The Cochrane Collaboration, 2011. Available from www.cochrane-handbook.org.

\section{Hinds 2008}

Hinds PS. Patient-reported outcomes: a desirable specialty standard for oncology or an incomplete measurement approach?. Cancer Nursing 2008;31(4):259-60.

\section{Holdsworth 2006}

Holdsworth MT, Raisch DW, Frost J. Acute and delayed nausea and emesis control in pediatric oncology patients. Cancer 2006;106(4):931-40.

\section{Juni 2002}

Juni P, Holenstein F, Sterne J, Bartlett C, Egger M. Direction and impact of language bias in meta-analyses of controlled trials: empirical study. International Journal of Epidemiology 2002;31(1):115-23.

\section{Kremer 2014}

Kremer LCM, Leclercq E, van Dalen EC. Cochrane Childhood Cancer Group. About The Cochrane Collaboration (Cochrane Review Groups (CRGs)) 2014, issue 8. Art. No.: CHILDCA.

\section{Kris 2005}

Kris MG, Hesketh PJ, Herrstedt J, Rittenberg C, Einhorn LH, Grunberg SM, et al. Consensus proposals for the prevention of acute and delayed vomiting and nausea following high-emeticrisk chemotherapy. Supportive Care in Cancer 2005;13(2):85-96.

\section{Lansky 1987}

Lansky SB, List MA, Lansky LL, Ritter-Sterr C, Miller DR. The measurement of performance in childhood cancer patients. Cancer 1987;60:1651-6.

\section{Linder 2005}

Linder LA. Measuring physical symptoms in children and adolescents with cancer. Cancer Nursing 2005;28(1):16-26.

\section{McCorcle 1998}

McCorcle R, Cooley M, Shea JA. A User's Manual for the Symptom Distress Scale. Philadelphia: University of Pennsylvania - National Institute of Nursing Research, 1998.

\section{Meyer 2006}

Meyer S, Eden T, Kalirai H. Dexamethasone protects against cisplatin-induced activation of the mitochondrial apoptotic pathway in human osteosarcoma cells. Cancer Biology \& Therapy 2006;5(8):915-20.

\section{Moher 2003}

Moher D, Pham B, Lawson ML, Klassen TP. The inclusion of reports of randomised trials published in languages other than English in systematic reviews. Health Technology Assessment (Winchester, England) 2003;7(41):1-90. 


\section{Moody 2006}

Moody K, Meyer M, Mancuso CA, Charlson M, Robbins L. Exploring concerns of children with cancer. Supportive Care in Cancer 2006;14(9):960-6.

\section{Peters 2008}

Peters JL, Sutton AJ, Jones DR, Abrams KR, Rushton L. Contour-enhanced meta-analysis funnel plots help distinguish publication bias from other causes of asymmetry. Journal of Clinical Epidemiology 2008;61(10):991-6.

\section{RevMan 2014 [Computer program]}

The Nordic Cochrane Centre. The Cochrane Collaboration. Review Manager (RevMan). Version 5.3. Copenhagen: The Nordic Cochrane Centre. The Cochrane Collaboration, 2014.

\section{Rheingans 2008}

Rheingans Jl. Pediatric oncology nurses' management of patients' symptoms. Journal of Pediatric Oncology Nursing 2008;25(6):303-11.

\section{Richardson 2007}

Richardson J, Smith JE, McCall G, Richardson A, Pilkington K, Kirsch I. Hypnosis for nausea and vomiting in cancer chemotherapy: a systematic review of the research evidence. European Journal of Cancer Care 2007;16(5):402-12.

\section{Roila 2005}

Roila F, Feyer P, Maranzano E, Olver I, Clark-Snow R, Warr D, et al. Antiemetics in children receiving chemotherapy. Supportive Care in Cancer 2005;13(2):129-31.

\section{Sammons 2009}

Sammons H. Ethical issues of clinical trials in children: a European perspective. Archives of Disease in Childhood 2009;94(6):474-7.

\section{Skoup 1990}

Skoup M. A comparison of two dose levels of granisetron in patients receiving high dose cisplatin. European Journal of Cancer 1990;26(Suppl 1):15-9.

\section{Smith 1990}

Smith IE. A comparison of two dose levels of granisetron in patients receiving moderately emetogenic cytostatic chemotherapy. European Journal of Cancer 1990;26(Suppl 1):19-23.

\section{Sutton 2008}

Sutton AJ, Higgins JPT. Recent developments in meta-analysis Statistics in Medicine 2008;27(5):625-50.

\section{Tallon 2000}

Tallon D, Chard J, Dieppe P. Relation between agendas of the research community and the research consumer. The Lancet 2000;355(9220):2037-40.

\section{Tremont-Lukats 2007}

Tremont-Lukats IW, Bruera E, González-Barboteo J. Neurokinin-1 receptor antagonists for prevention of chemotherapy-related nausea and vomiting in adults.
Cochrane Database of Systematic Reviews 2007, Issue 4. [DOI: 10.1002/14651858.CD006844]

\section{WHO 2007}

WHO. Make medicines child size. http://www.who.int/ childmedicines/en/index.html 6 Dec 2007 (accessed October 2009).

\section{Wilby 2005}

Wilby J, Kainth A, Hawkins N, Epstein D, McIntosh H, McDaid C, et al. Clinical effectiveness, tolerability and cost-effectiveness of newer drugs for epilepsy in adults: a systematic review and economic evaluation. Health Technology Assessment (Winchester, England) 2005;9(15):1-157, iii-iv-1-157, iii-iv.

\section{Williams 2006}

Williams PD, Schmideskamp J, Ridder EL, Williams AR. Symptom monitoring and dependent care during cancer treatment in children: pilot study. Cancer Nursing 2006;29(3):188-97.

\section{Wolfe 2000}

Wolfe J, Grier HE, Klar N, Levin SB, Ellenbogen JM, SalemSchatz $S$, et al. Symptoms and suffering at the end of life in children with cancer. The New England Journal of Medicine 2000;342(5):326-33.

\section{Woodgate 2003}

Woodgate RL, Degner LF, Yanofsky R. A different perspective to approaching cancer symptoms in children. Journal of Pain and Symptom Management 2003;26(3):800-17.

\section{Woodgate 2005}

Woodgate RL. A different way of being: adolescents' experiences with cancer. Cancer Nursing 2005;28(1):8-15.

\section{Zeltzer 1991}

Zeltzer LK, Dolgin MJ, LeBaron S, LeBaron C. A randomized, controlled study of behavioral intervention for chemotherapy distress in children with cancer. Pediatrics 1991;88(1):34-42.

\section{Zhang 2006}

Zhang C, Beckermann B, Kallifatidis G, Liu Z, Rittgen W, Edler L, et al. Corticosteroids induce chemotherapy resistance in the majority of tumour cells from bone, brain, breast, cervix, melanoma and neuroblastoma. International Journal of Oncology 2006;29(5):1295-301.

\section{Zou 2007}

Zou GY. One relative risk versus two odds ratios: implications for meta-analyses involving paired and unpaired binary data. Clinical Trials 2007;4(1):25-31.

\section{References to other published versions of this review}

\section{Phillips 2009}

Phillips RS, Gibson F, Gopaul S, Light K, Craig JV, Pizer B. Antiemetic medication for prevention and treatment of chemotherapy induced nausea and vomiting in childhood 
(Protocol). Cochrane Database of Systematic Reviews 2009, Issue 2. [DOI: 10.1002/14651858.CD007786]

\section{Phillips 2010}

Phillips RS, Gopaul S, Gibson F, Houghton E, Craig JV, Light K, Pizer B. Antiemetic medication for prevention and treatment

\section{CHARACTERISTICS OF STUDIES}

Characteristics of included studies [ordered by study ID] of chemotherapy induced nausea and vomiting in childhood. Cochrane Database of Systematic Reviews 2010, Issue 9. [DOI: 10.1002/14651858.CD007786.pub2]

* Indicates the major publication for the study

\section{Alvarez 1995}

\begin{tabular}{ll} 
Methods & RCT \\
& Cross-over \\
\hline Participants & $\begin{array}{l}\text { Participants aged } 9 \text { years median (range } 3 \text { to } 18 \text { years) with solid tumours receiving "emetogenic" } \\
\text { chemotherapy. } 19 / 33 \text { participants were male. Cross-over on an identical course. Chemotherapy con- } \\
\text { sisted of } 4 \text { - to } 5 \text {-day ifosfamide } 1.8 \mathrm{~g} / \mathrm{m}^{2} \text { to } 2.5 \mathrm{~g} / \mathrm{m}^{2} \text { plus doxorubicin } 25 \mathrm{mg} / \mathrm{m}^{2} \text { or etoposide } 100 \mathrm{mg} / \\
\mathrm{m}^{2} ; 4 \text { - to } 5 \text {-day cisplatin } 20 \text { to } 120 \mathrm{mg} / \mathrm{m}^{2} \text { plus etoposide, doxorubicin, cyclophosphamide, or ifos- } \\
\text { famide; } 1 \text {-day cyclophosphamide } 1.2 \mathrm{~g} \text { to } 2.2 \mathrm{~g} \text { plus doxorubicin and actinomycin; } 1 \text {-day carboplatin } \\
\text { 700 } \mathrm{mg} / \mathrm{m}^{2} \text {, or day } 1 \text { of ABVD. }\end{array}$
\end{tabular}

\begin{tabular}{ll}
\hline Interventions & Ondansetron, IV, $0.15 \mathrm{mg} / \mathrm{kg} 30$ minutes prior to chemo, then BD on chemotherapy for 1 to 5 days \\
& $\begin{array}{l}\text { Ondansetron, IV, } 0.15 \mathrm{mg} / \mathrm{kg} 30 \text { minutes prior to chemo, then BD on chemotherapy } \\
\text { Dexamethasone either } 4 \mathrm{mg} / \mathrm{m}^{2} \mathrm{QDS} \text { or } 8 \mathrm{mg} / \mathrm{m}^{2} \mathrm{BD} \text { (depended on institution) }\end{array}$ \\
\hline Outcomes & $\begin{array}{l}\text { Emetic episode defined as vomiting that produced liquid or any retches within a } 5 \text {-minute period. A } \\
\text { complete response was achieved if no emetic episode occurred. } 1 \text { or } 2 \text { emetic episodes constituted a } \\
\text { "major response". } 3 \text { to } 5 \text { episodes constituted a "minor response". More than } 5 \text { episodes, the need for } \\
\text { rescue medication, or participant withdrawal constituted a "failure". } \\
\text { Unvalidated nausea assessment of "none, a little, some, a lot" }\end{array}$ \\
\hline Notes & $\begin{array}{l}\text { Data reported by episode; no paired analysis possible. } 2 \text { institutions and dexamethasone dose varied } \\
\text { (see above) }\end{array}$ \\
\hline
\end{tabular}

\section{Risk of bias}

\begin{tabular}{|c|c|c|}
\hline Bias & Authors' judgement & Support for judgement \\
\hline $\begin{array}{l}\text { Random sequence genera- } \\
\text { tion (selection bias) }\end{array}$ & Low risk & Stated randomised \\
\hline $\begin{array}{l}\text { Allocation concealment } \\
\text { (selection bias) }\end{array}$ & Unclear risk & Randomisation list given to institutional pharmacy \\
\hline \multirow{3}{*}{$\begin{array}{l}\text { Blinding (performance } \\
\text { bias and detection bias) } \\
\text { Acute nausea }\end{array}$} & Low risk & Blinding of care provider: yes \\
\hline & & Blinding of participant: yes \\
\hline & & Blinding of outcome assessors: yes (as above, and nursing staff) \\
\hline \multirow{3}{*}{$\begin{array}{l}\text { Blinding (performance } \\
\text { bias and detection bias) } \\
\text { Acute vomiting }\end{array}$} & Low risk & Blinding of care provider: yes \\
\hline & & Blinding of participant: yes \\
\hline & & Blinding of outcome assessors: yes (as above, and nursing staff) \\
\hline
\end{tabular}


Alvarez 1995 (Continued)
Blinding (performance
Unclear risk
Not reported
bias and detection bias)

Other outcomes

\begin{tabular}{|c|c|c|}
\hline $\begin{array}{l}\text { Incomplete outcome data } \\
\text { (attrition bias) } \\
\text { All outcomes }\end{array}$ & High risk & $\begin{array}{l}33 \text { had } 1 \text { course, } 25 \text { had } 2 \text { courses (= } 58 \text { episodes). Loss after course } 1=1 \text { death, } \\
3 \text { PD, and } 4 \text { "failures" }\end{array}$ \\
\hline $\begin{array}{l}\text { Selective reporting (re- } \\
\text { porting bias) }\end{array}$ & Low risk & All outcomes reported \\
\hline Other bias & Unclear risk & Note a variety of chemotherapies used (with different emetogenicity) \\
\hline
\end{tabular}

\section{Basade 1996}

\begin{tabular}{ll}
\hline Methods & RCT \\
& Cross-over \\
\hline Participants & $\begin{array}{l}27 \text { children with any paediatric malignancy, receiving chemotherapy that included cyclophosphamide } \\
>600 \mathrm{mg} / \mathrm{m}^{2} \text {. Median } 7 \text { years (range } 3 \text { to } 14 \text { years) }\end{array}$ \\
\hline Interventions & Dexamethasone $8 \mathrm{mg} / \mathrm{m}^{2} \mathrm{IV} 15$ minutes prior to chemotherapy \\
\hline Outcomes & Metoclopramide $1.5 \mathrm{mg} / \mathrm{kg}$ IV 15 minutes prior to chemotherapy \\
& $\begin{array}{l}\text { Emetic episodes recorded by doctor, participant, or nurse. Unvalidated vomiting assessment, where } \\
\text { severe". }\end{array}$ \\
\hline Notes & Paired data not presented
\end{tabular}

\section{Risk of bias}

Bias Authors' judgement Support for judgement

Random sequence genera- Low risk Stated randomised

tion (selection bias)

\begin{tabular}{lll}
\hline $\begin{array}{l}\text { Allocation concealment } \\
\text { (selection bias) }\end{array}$ & Unclear risk & Not stated \\
\hline $\begin{array}{l}\text { Blinding (performance } \\
\text { bias and detection bias) }\end{array}$ & Unclear risk & Blinding of care provider: unclear \\
Acute nausea & Blinding of participant: unclear \\
& Blinding of outcome assessors: unclear \\
& Stated "single blind" but no further information \\
\hline
\end{tabular}

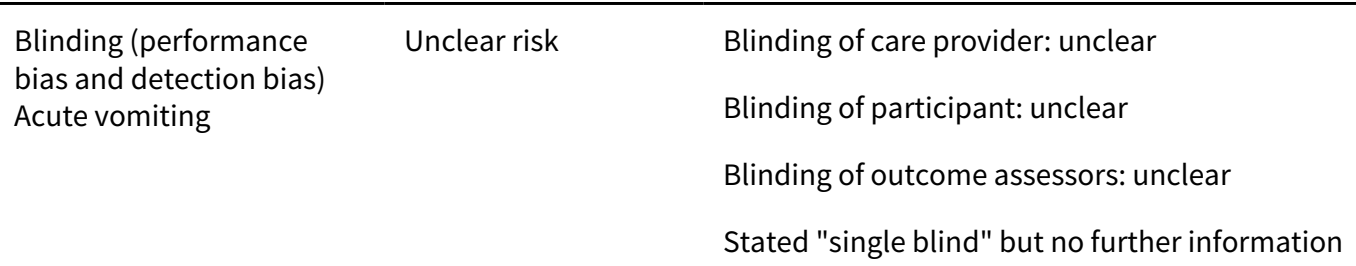


Basade 1996 (Continued)
Blinding (performance
High risk
Not reported
bias and detection bias)

Other outcomes

\begin{tabular}{lll}
\hline $\begin{array}{l}\text { Incomplete outcome data } \\
\text { (attrition bias) } \\
\text { All outcomes }\end{array}$ & High risk & 1 participant (2.9\%) failed to complete cross-over; no reason given \\
\hline $\begin{array}{l}\text { Selective reporting (re- } \\
\text { porting bias) }\end{array}$ & Low risk & All outcomes reported \\
\hline Other bias & Low risk & No other risks of bias noted \\
\hline
\end{tabular}

\section{Berrak 2007}

\begin{tabular}{ll}
\hline Methods & RCT \\
& Cross-over \\
\hline Participants & 18 participants with optic pathway glioma receiving carboplatin. 7.7 years median age (1 to 23 years) \\
\hline Interventions & Granisetron, OD, IV, $10 \mathrm{mcg} / \mathrm{kg}$ \\
& Granisetron, OD, IV, $40 \mathrm{mcg} / \mathrm{kg}$ \\
\hline Outcomes & Diary collected vomiting assessment \\
\hline Notes & $\begin{array}{l}\text { Investigator helpfully supplied data to extract paired, first cross-over analysis for immediate and de- } \\
\text { layed vomiting }\end{array}$ \\
\hline
\end{tabular}

\section{Risk of bias}

\begin{tabular}{lll}
\hline Bias & Authors' judgement & Support for judgement \\
\hline $\begin{array}{l}\text { Random sequence genera- } \\
\text { tion (selection bias) }\end{array}$ & Low risk & $\begin{array}{l}\text { "The dose of granisetron was randomly ordered by two physicians (ET and } \\
\text { BB)." }\end{array}$ \\
\hline $\begin{array}{l}\text { Allocation concealment } \\
\text { (selection bias) }\end{array}$ & Low risk & $\begin{array}{l}\text { "The study blind was maintained using a double dummy technique ... two } \\
\text { physicians (ET and BB) who were not involved in either the collection or evalu- } \\
\text { ation of self-report diary cards or safety assessments." }\end{array}$ \\
$\begin{array}{ll}\text { Blinding (performance } \\
\text { bias and detection bias) }\end{array}$ & High risk & Not reported \\
\hline $\begin{array}{l}\text { Acute nausea } \\
\text { Blinding (performance }\end{array}$ & Low risk detection bias) & "granisetron was prepared accordingly by the pharmacy in similar syringes la- \\
$\begin{array}{l}\text { Acute vomiting } \\
\text { belled simply 'granisetron'" }\end{array}$ & $\begin{array}{l}\text { Blinding of care provider: yes } \\
\text { Blinding of participant: yes }\end{array}$ \\
$\begin{array}{l}\text { Blinding (performance } \\
\text { bias and detection bias) }\end{array}$ & Low risk & Blinding of outcome assessors: yes (as above, and nursing staff) \\
\hline
\end{tabular}


Berrak 2007 (Continued)

"granisetron was prepared accordingly by the pharmacy in similar syringes labelled simply 'granisetron'"

Blinding of care provider: yes

Blinding of participant: yes

Blinding of outcome assessors: yes (as above, and nursing staff)

Incomplete outcome data Low risk $\quad$ Complete data available
(attrition bias)

All outcomes

\begin{tabular}{lll}
$\begin{array}{l}\text { Selective reporting (re- } \\
\text { porting bias) }\end{array}$ & Low risk & All outcome data available \\
\hline Other bias & Low risk & No other risk of bias noted \\
\hline
\end{tabular}

Brock 1996

\begin{tabular}{ll}
\hline Methods & RCT \\
\hline Participants & All participants scheduled to receive highly emetogenic chemotherapy except brain tumours, cerebral \\
metastases, or meningeal leukaemia, where highly emetogenic chemotherapy was defined as: & Actinomycin $>15 \mathrm{mcg} / \mathrm{kg}$ or $>0.45 \mathrm{mg} / \mathrm{m}^{2}$ \\
Carboplatin $>400 \mathrm{mg} / \mathrm{m}^{2}$ & Cisplatin $>20 \mathrm{mg} / \mathrm{m}^{2}$ \\
& Cyclophosphamide $>500 \mathrm{mg} / \mathrm{m}^{2}$ \\
& Cytosine $>500 \mathrm{mg} / \mathrm{m}^{2}$ \\
& Dacarbazine $>250 \mathrm{mg} / \mathrm{m}^{2}$ \\
& Daunorubicin $>40 \mathrm{mg} / \mathrm{m}^{2}$ \\
& Doxorubicin $>40 \mathrm{mg} / \mathrm{m}^{2}$ \\
Ifosfamide $>1 \mathrm{~g} / \mathrm{m}^{2}$ & Methotrexate $>5 \mathrm{~g} / \mathrm{m}^{2}$ \\
Mitoxantrone $>8 \mathrm{mg} / \mathrm{m}^{2}$ \\
Nitrogen mustard $>6 \mathrm{mg} / \mathrm{m}^{2}$ \\
Epirubicin $>45 \mathrm{mg} / \mathrm{m}^{2}$ \\
Mean age 8.5 years $(\mathrm{range} 1.9$ to 16.7 years), 102/160 participants were male
\end{tabular}

Interventions Ondansetron $5 \mathrm{mg} / \mathrm{m}^{2} \mathrm{IV}$ over 15 minutes immediately prior to chemotherapy, then 8 hours and 16 hours after initial dose. From day 2 ondansetron given orally $<1 \mathrm{~m}^{2} 4 \mathrm{mg} T \mathrm{TS},>1 \mathrm{~m}^{2} 8 \mathrm{mg}$ TDS, continued for 3 days after last day of chemotherapy or 5 days if nausea and vomiting persisted.

Ondansetron $10 \mathrm{mg} / \mathrm{m}^{2} \mathrm{IV}$ over 15 minutes immediately prior to chemotherapy, then $5 \mathrm{mg} / \mathrm{m}^{2} \mathrm{IV} 8$ hours and 16 hours after initial dose. From day 2 ondansetron given orally $<1 \mathrm{~m}^{2} 4 \mathrm{mg}$ TDS, $>1 \mathrm{~m}^{2} 8 \mathrm{mg}$ TDS, continued for 3 days after last day of chemotherapy or 5 days if nausea and vomiting persisted

Outcomes Emesis recorded as timing and number of episodes of vomiting or retching. Unvalidated nausea assessment of "none, mild or severe" on diary cards

Notes -

\section{Risk of bias}




\section{Brock 1996 (Continued)}

$\begin{aligned} & \text { Random sequence genera- } \\ & \text { tion (selection bias) }\end{aligned}$
Unclear risk $\quad$ Not stated

Allocation concealment $\quad$ Unclear risk $\quad$ Not stated
(selection bias)

\begin{tabular}{|c|c|c|}
\hline \multirow{4}{*}{$\begin{array}{l}\text { Blinding (performance } \\
\text { bias and detection bias) } \\
\text { Acute nausea }\end{array}$} & Low risk & $\begin{array}{l}\text { "The anti-emetic loading dose of ondansetron was blinded to the clinicians, } \\
\text { the patients, the parents and the nurses." }\end{array}$ \\
\hline & & Blinding of care provider: yes \\
\hline & & Blinding of participant: yes \\
\hline & & Blinding of outcome assessors: yes \\
\hline
\end{tabular}

\begin{tabular}{ll}
\hline $\begin{array}{l}\text { Blinding (performance } \\
\text { bias and detection bias) }\end{array}$ & Low risk \\
$\begin{array}{l}\text { Acute vomiting } \\
\text { the patients, the parents and the nurses." }\end{array}$ & $\begin{array}{l}\text { Blinding of care provider: yes } \\
\text { Blinding of participant: yes }\end{array}$ \\
Blinding of outcome assessors: yes
\end{tabular}

Blinding (performance $\quad$ High risk $\quad$ Not reported
bias and detection bias)
Other outcomes

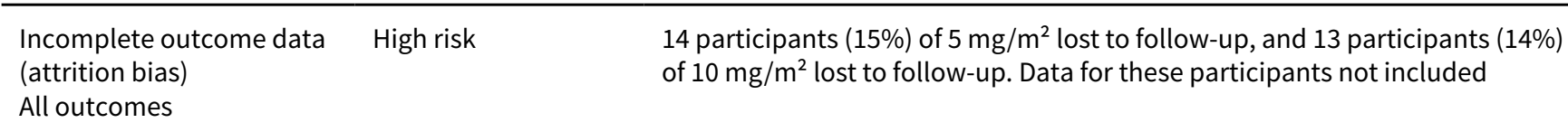

\begin{tabular}{lll}
\hline $\begin{array}{l}\text { Selective reporting (re- } \\
\text { porting bias) }\end{array}$ & Low risk & All outcomes reported \\
\hline Other bias & Low risk & No other risk of bias noted \\
\hline
\end{tabular}

Chan 1987

\begin{tabular}{ll}
\hline Methods & RCT \\
& Cross-over \\
\hline Participants & $\begin{array}{l}\text { Any paediatric malignancy, but patients in whom a chemotherapy cycle was previously shown to cause } \\
\text { moderate to severe drug-induced nausea and vomiting }\end{array}$ \\
& No participants received cisplatin. Participants had not previously been treated with either nabilone or \\
& prochlorperazine. 30 participants, median age 11.8 years (3.5 to 17.8 years), gender not specified \\
& Nabilone orally $(1$ mg capsules) starting 8 to 12 hours prior to chemotherapy and repeated 2 or 3 times \\
& a day according to dosage schedule \\
& Original schedule: \\
& 18 to $27 \mathrm{~kg} 1 \mathrm{mg}$ BD \\
& 27.1 to $36 \mathrm{~kg} 1 \mathrm{mg}$ TDS \\
& $>36 \mathrm{~kg} 2 \mathrm{mg}$ BD \\
& Modified schedule: \\
& $<18 \mathrm{~kg} 0.5 \mathrm{mg}$ BD
\end{tabular}


Chan 1987 (Continued)

18 to $30 \mathrm{~kg} 1 \mathrm{mg} \mathrm{BD}$

$>30 \mathrm{~kg} 1 \mathrm{mg}$ TDS

Prochlorperazine orally (capsules) starting 8 to 12 hours prior to chemotherapy and repeated 2 or 3 times a day according to dosage schedule

Original schedule:

18 to $27 \mathrm{~kg} 5 \mathrm{mg} \mathrm{BD}$

27.1 to $36 \mathrm{~kg} 5 \mathrm{mg}$ TDS

$>36 \mathrm{~kg} 10 \mathrm{mg} \mathrm{BD}$

Modified schedule:

$<18 \mathrm{~kg} 2.5 \mathrm{mg} \mathrm{BD}$

18 to $30 \mathrm{~kg} 5 \mathrm{mg} \mathrm{BD}$

$>30 \mathrm{~kg} 5 \mathrm{mg}$ TDS

\begin{tabular}{ll}
\hline Outcomes & Vomiting was recorded as the total number of episodes of vomiting or retching \\
\hline Notes & Study supported by a grant from Eli Lilly (company supplying nabilone) \\
\hline
\end{tabular}

\section{Risk of bias}

\begin{tabular}{lll}
\hline Bias & Authors' judgement & Support for judgement \\
\hline $\begin{array}{l}\text { Random sequence genera- } \\
\text { tion (selection bias) }\end{array}$ & Unclear risk & Not stated \\
\hline $\begin{array}{l}\text { Allocation concealment } \\
\text { (selection bias) }\end{array}$ & Unclear risk & Not stated \\
\hline $\begin{array}{l}\text { Blinding (performance } \\
\text { bias and detection bias) }\end{array}$ & High risk & Not reported \\
$\begin{array}{ll}\text { Acute nausea } \\
\begin{array}{l}\text { Blinding (performance } \\
\text { bias and detection bias) }\end{array}\end{array}$ & Unclear risk & \\
Acute vomiting & & $\begin{array}{l}\text { Medical staff and participants/parents not aware of drug allocation, but } \\
\text { nabilone has frequent, significant, and immediately identifiable side effects }\end{array}$ \\
& & Blinding of care provider: unclear \\
& & Blinding of participant: unclear \\
\end{tabular}

Blinding (performance High risk Not reported

bias and detection bias)

Other outcomes

Incomplete outcome data Low risk

(attrition bias)

All outcomes
10 withdrawals, all included in toxicity assessments. 4 change of chemotherapy after cycle $1 ; 2$ unable to cope with diagnosis and treatment; 2 received other antiemetics during study period; 2 cycle 2 of chemotherapy deferred because of severe dizziness/drowsiness after a single $2 \mathrm{mg}$ dose of nabilone prior to treatment

\begin{tabular}{lll}
\hline $\begin{array}{l}\text { Selective reporting (re- } \\
\text { porting bias) }\end{array}$ & Low risk & All outcomes reported \\
\hline Other bias & Low risk & No other risk of bias noted \\
\hline
\end{tabular}


Dalzell 1986

\begin{tabular}{ll}
\hline Methods & RCT \\
& Cross-over \\
\hline Participants & $\begin{array}{l}\text { Any paediatric malignancy, as long as 2+ identical courses of chemotherapy scheduled. Only } 1 \text { with cis- } \\
\text { platin, mainly had high-dose cyclophosphamide. Mean age } 8.6 \text { years (range } 0.8 \text { to } 17 \text { years), } 18 / 23 \text { par- } \\
\text { ticipants were male }\end{array}$ \\
\hline Interventions & Nabilone $0.5 \mathrm{mg} \mathrm{BD}$ if $<18 \mathrm{~kg}, 1 \mathrm{mg}$ BD if 18 to $36 \mathrm{~kg}, 1 \mathrm{mg}$ TDS if $>36 \mathrm{~kg}$ \\
\hline Outcomes & $\begin{array}{l}\text { Vomiting episodes recorded. Nausea assessed as "0, } 1,2,3 \text { ", but unclear if as a visual analogue scale } \\
\text { or integers to circle/tick. No indication of the performance of the tool (e.g. is "3" three times as bad as } \\
\text { "1"?) }\end{array}$ \\
\hline Notes & Only data on completers were used \\
\hline
\end{tabular}

\section{Risk of bias}

\begin{tabular}{|c|c|c|}
\hline Bias & Authors' judgement & Support for judgement \\
\hline $\begin{array}{l}\text { Random sequence genera- } \\
\text { tion (selection bias) }\end{array}$ & Unclear risk & Not stated \\
\hline $\begin{array}{l}\text { Allocation concealment } \\
\text { (selection bias) }\end{array}$ & Unclear risk & Not stated \\
\hline $\begin{array}{l}\text { Blinding (performance } \\
\text { bias and detection bias) } \\
\text { Acute nausea }\end{array}$ & High risk & Not reported \\
\hline $\begin{array}{l}\text { Blinding (performance } \\
\text { bias and detection bias) } \\
\text { Acute vomiting }\end{array}$ & High risk & Not reported \\
\hline $\begin{array}{l}\text { Blinding (performance } \\
\text { bias and detection bias) } \\
\text { Other outcomes }\end{array}$ & Unclear risk & $\begin{array}{l}\text { Medical staff and participants/parents not aware of drug allocation, but } \\
\text { nabilone has frequent, significant, and immediately identifiable side effects } \\
\text { Blinding of care provider: unclear } \\
\text { Blinding of participant: unclear } \\
\text { Blinding of outcome assessors: unclear }\end{array}$ \\
\hline $\begin{array}{l}\text { Incomplete outcome data } \\
\text { (attrition bias) } \\
\text { All outcomes }\end{array}$ & High risk & $\begin{array}{l}\text { Only } 18 / 23 \text { participants ( } 78 \% \text { ) completed cross-over; } 2 \text { lost from nabilone arm, } \\
3 \text { from metoclopramide arm }\end{array}$ \\
\hline $\begin{array}{l}\text { Selective reporting (re- } \\
\text { porting bias) }\end{array}$ & Low risk & All outcomes reported \\
\hline Other bias & Low risk & No other risk of bias noted \\
\hline
\end{tabular}


Dick 1995

\begin{tabular}{|c|c|}
\hline Methods & $\mathrm{RCT}$ \\
\hline Participants & $\begin{array}{l}30 \text { participants with ALL undergoing MRC Intensification (daunorubicin, etoposide, and high-dose cy- } \\
\text { tarabine). Age and gender of participants not recorded }\end{array}$ \\
\hline \multirow[t]{2}{*}{ Interventions } & $\begin{array}{l}15 \text { participants received ondansetron } 3 \text { to } 8 \mathrm{mg} / \mathrm{m}^{2} \text { given pre-chemotherapy, then BD initially IV then } \\
\text { orally for } 3 \text { days (dose }<0.6 \mathrm{~m}^{2} \text { - load } 3 \mathrm{mg} / \mathrm{m}^{2} \text {, maint } 3 \mathrm{mg} / \mathrm{m}^{2} \text { or } 2 \mathrm{mg} ; 0.6 \text { to } 1.2 \mathrm{~m}^{2} \text { - load } 3 \mathrm{mg} / \mathrm{m}^{2} \text {, } \\
\text { maint } 3 \mathrm{mg} / \mathrm{m}^{2} \text { or } 4 \mathrm{mg} ;>1.2 \mathrm{~m}^{2} \text { - load } 8 \mathrm{mg} \text {, maint } 8 \mathrm{mg} \text { ) }\end{array}$ \\
\hline & $\begin{array}{l}15 \text { participants received metoclopramide } 10 \mathrm{mg} / \mathrm{m}^{2} \text { IV QDS for } 3 \text { days, with } 2.5 \mathrm{mg} \text { procyclidine. Dex- } \\
\text { amethasone } 4 \mathrm{mg} / \mathrm{m}^{2} \text { IV then } 2 \mathrm{mg} / \mathrm{m}^{2} \text { TDS IV or PO }\end{array}$ \\
\hline Outcomes & $\begin{array}{l}\text { Vomiting numbers recorded on diary cards. Unvalidated nausea assessment of "not feeling very sick at } \\
\text { all, feeling sick, feeling very sick" }\end{array}$ \\
\hline Notes & - \\
\hline
\end{tabular}

\section{Risk of bias}

\begin{tabular}{|c|c|c|}
\hline Bias & Authors' judgement & Support for judgement \\
\hline $\begin{array}{l}\text { Random sequence genera- } \\
\text { tion (selection bias) }\end{array}$ & Unclear risk & Stated "block balanced" but no further detail given \\
\hline $\begin{array}{l}\text { Allocation concealment } \\
\text { (selection bias) }\end{array}$ & Low risk & "coding held in the pharmacy." \\
\hline $\begin{array}{l}\text { Blinding (performance } \\
\text { bias and detection bias) } \\
\text { Acute nausea }\end{array}$ & High risk & Not reported \\
\hline $\begin{array}{l}\text { Blinding (performance } \\
\text { bias and detection bias) } \\
\text { Acute vomiting }\end{array}$ & High risk & Not reported \\
\hline $\begin{array}{l}\text { Blinding (performance } \\
\text { bias and detection bias) } \\
\text { Other outcomes }\end{array}$ & High risk & $\begin{array}{l}\text { Combined nausea and vomiting } \\
\text { Blinding of care provider: no } \\
\text { Blinding of participant: no } \\
\text { Blinding of outcome assessors: no }\end{array}$ \\
\hline $\begin{array}{l}\text { Incomplete outcome data } \\
\text { (attrition bias) } \\
\text { All outcomes }\end{array}$ & Low risk & No dropouts or withdrawals \\
\hline $\begin{array}{l}\text { Selective reporting (re- } \\
\text { porting bias) }\end{array}$ & Low risk & All outcomes reported \\
\hline Other bias & High risk & $\begin{array}{l}10 \text { of } 15 \text { metoclopramide patients were switched to ondansetron during D1, so } \\
\text { 'contaminated' any ostensibly randomised comparisons of later efficacy }\end{array}$ \\
\hline
\end{tabular}

\section{Ekert 1979}

Methods RCT


Ekert 1979 (Continued)

Multiple randomisations per participant, each independent

Any paediatric malignancy. Age and gender not recorded.
$\begin{aligned} & \text { Any regimen of chemotherapy, with mixed emetogenicity. No platinums. Courses included: high- } \\ & \text { dose methotrexate }\left(7.5 \mathrm{~g} / \mathrm{m}^{2}\right)=6 \text {, lower-dose vincristine }\left(.625 \mathrm{~g} / \mathrm{m}^{2}\right)=5 \text {, doxorubicin }(60)=2 \text {, vin- } \\ & \text { cristine-doxorubicin-dacarbazine }=7 \text {, vincristine-prednisolone-cyclophosphamide-doxorubicin }=4, \\ & \text { cytosine-cyclophosphamide-asparaginase }=6 \text {, cytarabine } / 6 \text { Thioguanine }=3,5 \text { FU-doxorubicin-actino- } \\ & \text { mycinD }=2 \text {, lomustine-vincristine }=7\end{aligned}$

Interventions Tetrahydrocannabinol $10 \mathrm{mg} / \mathrm{m}^{2}$, given at $-2,4,8,16$, and 24 hours around chemotherapy administration

Metoclopramide $5 \mathrm{mg}$ (for $<0.7 \mathrm{~m}^{2}$ participants) or $10 \mathrm{mg}$ (for $>0.7 \mathrm{~m}^{2}$ participants) at $-2,8,16$, and 24 hours. Placebo given at +4 hours

\begin{tabular}{ll}
\hline Outcomes & $\begin{array}{l}\text { Nurse recorded outcomes (as inpatient) or parent/child recorded diary. Vomiting episodes and nausea } \\
\text { (present/absent) reported }\end{array}$
\end{tabular}
(present/absent) reported

Notes $\quad$ First of 2 randomisations, second reported as Ekert 1979a

\section{Risk of bias}

\begin{tabular}{|c|c|c|}
\hline Bias & Authors' judgement & Support for judgement \\
\hline $\begin{array}{l}\text { Random sequence genera- } \\
\text { tion (selection bias) }\end{array}$ & Unclear risk & Not stated \\
\hline $\begin{array}{l}\text { Allocation concealment } \\
\text { (selection bias) }\end{array}$ & Unclear risk & Not stated \\
\hline \multirow{4}{*}{$\begin{array}{l}\text { Blinding (performance } \\
\text { bias and detection bias) } \\
\text { Acute nausea }\end{array}$} & Unclear risk & $\begin{array}{l}\text { Stated "double blinded", but cannabinoids have frequent, significant, and im- } \\
\text { mediately identifiable side effects }\end{array}$ \\
\hline & & Blinding of care provider: unclear \\
\hline & & Blinding of participant: unclear \\
\hline & & Blinding of outcome assessors: unclear \\
\hline \multirow{4}{*}{$\begin{array}{l}\text { Blinding (performance } \\
\text { bias and detection bias) } \\
\text { Acute vomiting }\end{array}$} & Unclear risk & $\begin{array}{l}\text { Stated "double blinded", but cannabinoids have frequent, significant, and im- } \\
\text { mediately identifiable side effects }\end{array}$ \\
\hline & & Blinding of care provider: unclear \\
\hline & & Blinding of participant: unclear \\
\hline & & Blinding of outcome assessors: unclear \\
\hline $\begin{array}{l}\text { Blinding (performance } \\
\text { bias and detection bias) } \\
\text { Other outcomes }\end{array}$ & High risk & Not reported \\
\hline $\begin{array}{l}\text { Incomplete outcome data } \\
\text { (attrition bias) } \\
\text { All outcomes }\end{array}$ & Low risk & Full report of data \\
\hline $\begin{array}{l}\text { Selective reporting (re- } \\
\text { porting bias) }\end{array}$ & Low risk & - \\
\hline
\end{tabular}


Ekert 1979 (Continued)

$\begin{array}{ll}\text { Other bias } \quad \text { Unclear risk } & \begin{array}{l}\text { Stopped early because of failure of efficacy of metoclopramide (7 courses of } \\ \text { tetrahydrocannabinol "missed") }\end{array}\end{array}$
tetrahydrocannabinol "missed")

\section{Ekert 1979a}

\begin{tabular}{ll}
\hline Methods & RCT \\
Multiple randomisation per participant, each independent
\end{tabular}

Participants Any paediatric malignancy. Age and gender not recorded.

Any regimen of chemotherapy, with mixed emetogenicity. No platinums. Courses included: high-dose methotrexate $\left(7.5 \mathrm{~g} / \mathrm{m}^{2}\right)=4$, doxorubicin $(60)=3$, vinc-procarbazine-pred-lomustine $=12$, vinc-predcyclo-doxorubicin $=2$, cytosine-cyclo-asparaginase $=2,5 \mathrm{FU}$-dox-actinoD $=2$, lomustine-vinc $=2$, vincactinomycinD $=4$, vinc-6MP-dox-pred $=3$, cytosines-daunorubicin/doxorubicin $=2$

Age and sex not reported

Tetrahydrocannabinol $10 \mathrm{mg} / \mathrm{m}^{2}$, given at $-2,4,8,16$, and 24 hours around chemotherapy administra-
tion
Prochlorperazine - tablets. Complex schedule
SA 0.7 to $1.1 \mathrm{~m}^{2}=5 \mathrm{mg}$ at $-2,8,16,24$ hours
SA 1.1 to $1.4 \mathrm{~m}^{2}=10 \mathrm{mg}$ at $-2,8$ hours and $5 \mathrm{mg}$ at 16,24 hours
SA $>1.1 \mathrm{~m}^{2}=10 \mathrm{mg}$ at $-2,8,16,24$ hours
Placebo given at +4 hours

Outcomes Nurse recorded outcomes (as inpatient) or parent/child recorded diary. Vomiting episodes and nausea (present/absent) reported

\begin{tabular}{ll}
\hline Notes & Second randomisation in paper (see Ekert 1979) \\
\hline Risk of bias
\end{tabular}

\begin{tabular}{lll}
\hline Bias & Authors' judgement & Support for judgement \\
\hline $\begin{array}{l}\text { Random sequence genera- } \\
\text { tion (selection bias) }\end{array}$ & Unclear risk & Not stated \\
\hline $\begin{array}{l}\text { Allocation concealment } \\
\text { (selection bias) }\end{array}$ & Unclear risk & Not stated \\
\hline $\begin{array}{l}\text { Blinding (performance } \\
\text { bias and detection bias) }\end{array}$ & Unclear risk & $\begin{array}{l}\text { Stated "double blinded", but cannabinoids have frequent, significant, and im- } \\
\text { Acute nausea }\end{array}$ \\
& $\begin{array}{l}\text { mediately identifiable side effects } \\
\text { Blinding of care provider: unclear }\end{array}$ \\
& Blinding of participant: unclear \\
& Blinding of outcome assessors: unclear \\
\hline
\end{tabular}

\begin{tabular}{|c|c|c|}
\hline \multirow{3}{*}{$\begin{array}{l}\text { Blinding (performance } \\
\text { bias and detection bias) } \\
\text { Acute vomiting }\end{array}$} & Unclear risk & $\begin{array}{l}\text { Stated "double blinded", but cannabinoids have frequent, significant, and im- } \\
\text { mediately identifiable side effects }\end{array}$ \\
\hline & & Blinding of care provider: unclear \\
\hline & & Blinding of participant: unclear \\
\hline
\end{tabular}


Ekert 1979a (Continued)

Blinding of outcome assessors: unclear

\begin{tabular}{|c|c|c|}
\hline $\begin{array}{l}\text { Blinding (performance } \\
\text { bias and detection bias) } \\
\text { Other outcomes }\end{array}$ & Unclear risk & Not reported \\
\hline $\begin{array}{l}\text { Incomplete outcome data } \\
\text { (attrition bias) } \\
\text { All outcomes }\end{array}$ & Low risk & Full report of data \\
\hline $\begin{array}{l}\text { Selective reporting (re- } \\
\text { porting bias) }\end{array}$ & Low risk & - \\
\hline Other bias & Low risk & No other risk of bias noted \\
\hline
\end{tabular}

\section{Emir 2013}

\begin{tabular}{ll}
\hline Methods & RCT \\
& Cross-over \\
\hline Participants & $\begin{array}{l}\text { Paediatric patients (age } 1 \text { to } 16 \text { years, median } 7 \text { years; } 13 / 23 \text { male) receiving cisplatin-containing } \\
\text { chemotherapy regimens }\end{array}$ \\
\hline Interventions & Granisetron $0.04 \mathrm{mg} / \mathrm{kg}$ plus dexamethasone $0.2 \mathrm{mg} / \mathrm{kg}$ \\
& $\begin{array}{l}\text { Granisetron } 0.04 \mathrm{mg} / \mathrm{kg} \text {, dexamethasone } 0.2 \mathrm{mg} / \mathrm{kg} \text {, midazolam } 0.04 \mathrm{mg} / \mathrm{kg} \text {, and diphenhydramine } 2.5 \\
\mathrm{mg} / \mathrm{kg}\end{array}$
\end{tabular}

Number of vomits
Severity of nausea (no definition of how this was defined given in paper)
Use of rescue therapy
Adverse events
Complete response was defined as no nausea or vomiting, partial response as 1 or 2 vomits but no
need for rescue therapy, no response as more than 3 emetic episodes or need for rescue therapy

\section{Notes}

\section{Risk of bias}

\begin{tabular}{lll}
\hline Bias & Authors' judgement & Support for judgement \\
\hline $\begin{array}{l}\text { Random sequence genera- } \\
\text { tion (selection bias) }\end{array}$ & Unclear risk & Not stated \\
\hline $\begin{array}{l}\text { Allocation concealment } \\
\text { (selection bias) }\end{array}$ & Unclear risk & Not stated \\
\hline $\begin{array}{l}\text { Blinding (performance } \\
\text { bias and detection bias) } \\
\text { Acute nausea }\end{array}$ & Unclear risk & Not stated \\
\hline $\begin{array}{l}\text { Blinding (performance } \\
\text { bias and detection bias) }\end{array}$ & Unclear risk & Not stated \\
\hline
\end{tabular}

Antiemetic medication for prevention and treatment of chemotherapy-induced nausea and vomiting in childhood (Review) 
Emir 2013 (Continued)

Acute vomiting

Blinding (performance $\quad$ Unclear risk Not stated
bias and detection bias)
Other outcomes

Other outcomes

Incomplete outcome data Low risk $\quad$ All participants accounted for in results
(attrition bias)

All outcomes

\begin{tabular}{lll}
\hline $\begin{array}{l}\text { Selective reporting (re- } \\
\text { porting bias) }\end{array}$ & Low risk & All outcomes reported \\
\hline Other bias & Unclear risk & Paired data not provided \\
\hline
\end{tabular}

\section{Graham-Pole 1986}

\begin{tabular}{|c|c|}
\hline Methods & $\mathrm{RCT}$ \\
\hline \multirow[t]{2}{*}{ Participants } & $\begin{array}{l}50 \text { participants with any paediatric malignancy (included osteogenic sarcoma, AML, Ewing's sarco- } \\
\text { ma, and lymphoma). Chemotherapy included aggressive regimens, e.g. cisplatin } 100 \text { to } 120 \mathrm{mg} / \mathrm{m}^{2} \text {, } \\
\text { methotrexate }>7.5 \mathrm{~g} / \mathrm{m}^{2} \text {, cyclophosphamide }>900 \mathrm{mg} / \mathrm{m}^{2} \text {, and anthracyclines }>60 \mathrm{mg} / \mathrm{m}^{2} .12 \mathrm{partici}- \\
\text { pants were receiving conditioning for BMT with cytosine } 3 \mathrm{~g} / \mathrm{m}^{2} / \text { dose or melphalan } 60 \mathrm{mg} / \mathrm{m}^{2} / \text { dose }\end{array}$ \\
\hline & $40 / 50$ participants were younger than 10 years, and $34 / 50$ male \\
\hline \multirow[t]{2}{*}{ Interventions } & $\begin{array}{l}24 \text { participants received metoclopramide } 0.5 \mathrm{mg} / \mathrm{kg} / \mathrm{dose} \text { IV infusion over } 15 \text { minutes beginning } 30 \\
\text { minutes before chemotherapy and repeated every } 3 \text { hours for } 5 \text { doses }\end{array}$ \\
\hline & $\begin{array}{l}26 \text { participants received chlorpromazine } 0.5 \mathrm{mg} / \mathrm{kg} / \mathrm{dose} \text { IV infusion over } 15 \text { minutes starting } 30 \mathrm{~min} \text { - } \\
\text { utes before chemotherapy and repeated every } 3 \text { hours for } 5 \text { doses }\end{array}$ \\
\hline Outcomes & $\begin{array}{l}\text { Unvalidated nausea assessment with duration in hours recorded. Number and volume of vomits } \\
\text { recorded. Unclear who recorded the information }\end{array}$ \\
\hline Notes & - \\
\hline
\end{tabular}

\section{Risk of bias}

\begin{tabular}{lll}
\hline Bias & Authors' judgement & Support for judgement \\
\hline $\begin{array}{l}\text { Random sequence genera- } \\
\text { tion (selection bias) }\end{array}$ & Low risk & Participants assigned with a random numbers table \\
\hline $\begin{array}{l}\text { Allocation concealment } \\
\text { (selection bias) }\end{array}$ & Low risk & $\begin{array}{l}\text { Drugs prepared in inpatient pharmacy. Both supplied to ward in } 50 \text { ml normal } \\
\text { saline and labelled with "Reglan Study" and participant's name. Participants } \\
\text { and clinicians did not know which antiemetic was being used }\end{array}$ \\
\hline $\begin{array}{l}\text { Blinding (performance } \\
\text { bias and detection bias) }\end{array}$ & High risk & Not reported \\
\hline $\begin{array}{l}\text { Acute nausea } \\
\begin{array}{l}\text { Blinding (performance } \\
\text { bias and detection bias) } \\
\text { Acute vomiting }\end{array}\end{array}$ & High risk & Not reported \\
\hline
\end{tabular}


Graham-Pole 1986 (Continued)

$\begin{array}{ll}\begin{array}{l}\text { Blinding (performance } \\ \text { bias and detection bias) } \\ \text { Other outcomes }\end{array} & \begin{array}{l}\text { Not clear who collected data, but "only pharmacy were aware of drug alloca- } \\ \text { tion" }\end{array} \\ & \text { Blinding of care provider: yes } \\ & \text { Blinding of participant: yes } \\ \text { Blinding of outcome assessors: yes }\end{array}$

$\begin{array}{lll}\begin{array}{l}\text { Incomplete outcome data } \\ \text { (attrition bias) }\end{array} & \text { High risk } & \begin{array}{l}\text { Participants who experienced an extrapyramidal reaction had no further data } \\ \text { recorded }\end{array}\end{array}$

All outcomes recorded

\begin{tabular}{lll}
$\begin{array}{l}\text { Selective reporting (re- } \\
\text { porting bias) }\end{array}$ & Low risk & \\
\hline Other bias & High risk & Discrepancy on numbers of participants who had received prior chemotherapy \\
& & $19 / 24$ participants in metoclopramide group had prior chemotherapy \\
& $10 / 26$ participants in chlorpromazine group had prior chemotherapy
\end{tabular}

Hahlen 1995

\begin{tabular}{|c|c|}
\hline Methods & $\mathrm{RCT}$ \\
\hline \multirow[t]{3}{*}{ Participants } & $\begin{array}{l}88 \text { children with any paediatric malignancy, excluding primary or secondary brain tumour. Majority of } \\
\text { children had soft tissue sarcomas. }\end{array}$ \\
\hline & $\begin{array}{l}\text { Chemotherapy consisted of high-dose ifosfamide treatment }\left(>=3 \mathrm{~g} / \mathrm{m}^{2}\right) \text { for } 2 \text { or } 3 \text { consecutive days. } \\
\text { Other cytostatic agents, e.g. dactinomycin, doxorubicin, and vincristine, were permitted to be given } \\
\text { concurrently (as in most cases) or after completion of ifosfamide administration. }\end{array}$ \\
\hline & Mean age was 9.5 years, and around half the children were boys \\
\hline \multirow[t]{2}{*}{ Interventions } & $\begin{array}{l}46 \text { children received granisetron } 20 \mathrm{mcg} / \mathrm{kg} \text { in } 20 \mathrm{ml} \text { saline by IVI over } 5 \text { minutes, then ifosfamide infu- } \\
\text { sion started } \\
\text { Up to } 2 \text { further doses granisetron } 20 \mathrm{mcg} / \mathrm{kg} \text { per dose within each 24-hour period if moderate or severe } \\
\text { nausea or any vomiting (to a maximum of } 60 \mathrm{mcg} / \mathrm{kg} \text { in } 24 \text { hours) }\end{array}$ \\
\hline & $\begin{array}{l}42 \text { children received dexamethasone } 2 \mathrm{mg} / \mathrm{m}^{2} \text { by IVI } 30 \mathrm{minutes} \text { before ifosfamide infusion started, } \\
\text { then again at } 8 \text { and } 16 \text { hours, plus chlorpromazine } 0.5 \mathrm{mg} / \mathrm{kg} \text { by IVI } 25 \text { minutes before start of ifos- } \\
\text { famide and at } 4 \text { - to } 6 \text {-hourly intervals (reduced to } 0.3 \mathrm{mg} / \mathrm{kg} \text { loading dose and } 0.3 \text { to } 0.5 \mathrm{mg} / \mathrm{kg} \text { 4- to 6- } \\
\text { hourly after reports of unacceptable levels of sedation in some children) }\end{array}$ \\
\hline
\end{tabular}

Assessment of severity of nausea and frequency of vomiting or retching episodes during 6 hourly peri-
ods by hospital staff
At end of treatment period, subjective assessment of overall response to antiemetic therapy (very
good, good, average, poor, very poor) made by clinician
Unvalidated nausea assessment of none, mild, moderate, severe. Vomiting episodes recorded

Notes Stopped early due to emerging evidence of effectiveness and tolerability of granisetron over control therapy (88 out of 100 planned participants)

\section{Risk of bias}


Hahlen 1995 (Continued)

$\begin{array}{ll}\begin{array}{l}\text { Random sequence genera- } \\ \text { tion (selection bias) }\end{array} & \text { Low risk }\end{array} \quad \begin{aligned} & \text { Computer-generated randomisation code. Randomisation stratified to en- } \\ & \text { sure that 2-and 3-day ifosfamide treatments were evenly represented in both } \\ & \text { groups }\end{aligned}$

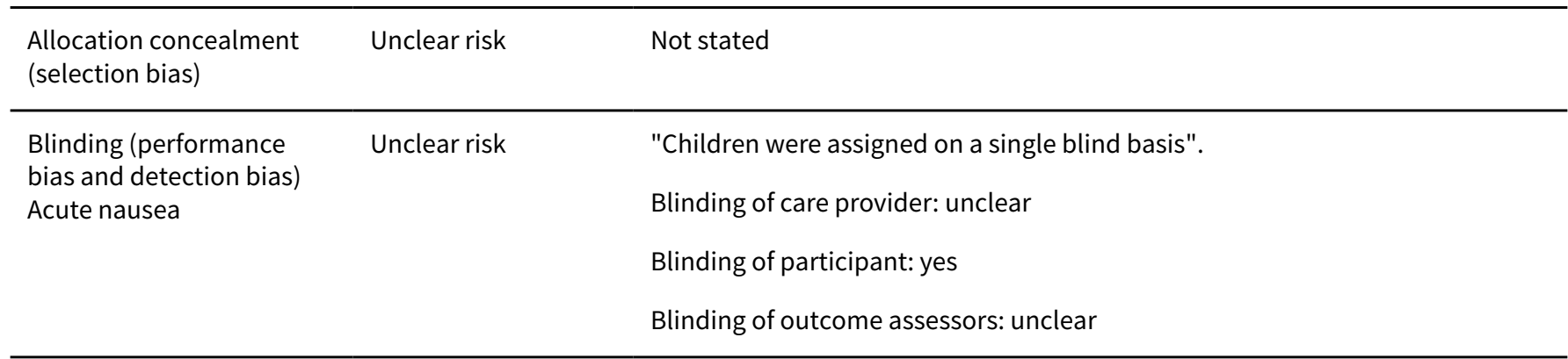

Blinding (performance Unclear risk

bias and detection bias)

Acute vomiting

\author{
"Children were assigned on a single blind basis". \\ Blinding of care provider: unclear \\ Blinding of participant: yes \\ Blinding of outcome assessors: unclear
}

\begin{tabular}{|c|c|c|}
\hline \multirow[t]{3}{*}{$\begin{array}{l}\text { Blinding (performance } \\
\text { bias and detection bias) } \\
\text { Other outcomes }\end{array}$} & Unclear risk & $\begin{array}{l}\text { "Children were assigned on a single blind basis". } \\
\text { Blinding of care provider: unclear }\end{array}$ \\
\hline & & Blinding of participant: yes \\
\hline & & Blinding of outcome assessors: unclear \\
\hline
\end{tabular}

\begin{tabular}{lll}
\hline $\begin{array}{l}\text { Incomplete outcome data } \\
\text { (attrition bias) } \\
\text { All outcomes }\end{array}$ & Unclear risk & $\begin{array}{l}\text { "... all children were included in efficacy and safety analysis", however unclear } \\
\text { if any missing outcomes at each time point }\end{array}$ \\
\hline $\begin{array}{l}\text { Selective reporting (re- } \\
\text { porting bias) }\end{array}$ & Low risk & - \\
\hline Other bias & Unclear risk & $\begin{array}{l}\text { Stopped early due to emerging evidence of effectiveness and tolerability of } \\
\text { granisetron over control therapy (88 out of } 100 \text { planned participants) }\end{array}$
\end{tabular}

\title{
Hirota 1993
}

\begin{tabular}{ll}
\hline Methods & RCT \\
& Cross-over \\
\hline
\end{tabular}

Participants
$\begin{aligned} & \text { Any chemotherapy protocol that was moderate or highly emetogenic, with } 2 \text { courses required (for } \\ & \text { cross-over) } \\ & \text { Mean age } 10.8 \text { years (4 to } 18 \text { years), 8/12 were male }\end{aligned}$

\begin{tabular}{ll}
\hline Interventions & Granisetron $40 \mathrm{mcg} / \mathrm{kg}$ IV 30 minutes prior to Rx \\
& Granisetron $40 \mathrm{mcg} / \mathrm{kg}$ IV 30 minutes prior to Rx plus methylprednisolone $10 \mathrm{mg} / \mathrm{kg}(\mathrm{max} 500 \mathrm{mg})$ IV \\
\hline Outcomes & Parents reported vomiting episodes
\end{tabular}


Hirota 1993 (Continued)
Notes
Paired data

\section{Risk of bias}

\begin{tabular}{|c|c|c|}
\hline Bias & Authors' judgement & Support for judgement \\
\hline $\begin{array}{l}\text { Random sequence genera- } \\
\text { tion (selection bias) }\end{array}$ & Unclear risk & Not stated \\
\hline $\begin{array}{l}\text { Allocation concealment } \\
\text { (selection bias) }\end{array}$ & Unclear risk & Not stated \\
\hline $\begin{array}{l}\text { Blinding (performance } \\
\text { bias and detection bias) } \\
\text { Acute nausea }\end{array}$ & Unclear risk & Not stated \\
\hline $\begin{array}{l}\text { Blinding (performance } \\
\text { bias and detection bias) } \\
\text { Acute vomiting }\end{array}$ & Unclear risk & Not reported \\
\hline $\begin{array}{l}\text { Blinding (performance } \\
\text { bias and detection bias) } \\
\text { Other outcomes }\end{array}$ & Unclear risk & Not reported \\
\hline $\begin{array}{l}\text { Incomplete outcome data } \\
\text { (attrition bias) } \\
\text { All outcomes }\end{array}$ & High risk & 2 participants did not complete cross-over. Data not given \\
\hline $\begin{array}{l}\text { Selective reporting (re- } \\
\text { porting bias) }\end{array}$ & Low risk & - \\
\hline Other bias & Low risk & No other risk of bias noted \\
\hline
\end{tabular}

Jaing 2004

\begin{tabular}{|c|c|}
\hline Methods & $\begin{array}{l}\text { RCT } \\
\text { Open-label, 2-period cross-over study }\end{array}$ \\
\hline Participants & $\begin{array}{l}\text { ALL with no CNS involvement who were receiving cyclophosphamide } 300 \mathrm{mg} / \mathrm{m}^{2} \text { plus etoposide } 300 \\
\mathrm{mg} / \mathrm{m}^{2} \text { or cyclophosphamide } 1000 \mathrm{mg} / \mathrm{m}^{2} \text { alone } \\
\text { Mean } 88 \text { months old with } 21 / 33 \text { males }\end{array}$ \\
\hline Interventions & $\begin{array}{l}\text { Oral granisetron single dose } 1 \text { hour before administration of chemotherapy } \\
25 \text { to } 50 \mathrm{~kg} 0.5 \mathrm{mg} \\
>50 \mathrm{~kg} 1 \mathrm{mg} \\
\text { Ondansetron } 0.15 \mathrm{mg} / \mathrm{kg} \mathrm{IV} 1 \text { hour before chemotherapy and } 4 \text { hours after the first dose. Oral dose giv- } \\
\text { en } 8 \text { hours after the first dose }\end{array}$ \\
\hline Outcomes & Parent reported number of vomiting episodes \\
\hline Notes & - \\
\hline
\end{tabular}

\section{Risk of bias}

Antiemetic medication for prevention and treatment of chemotherapy-induced nausea and vomiting in childhood (Review) 
Jaing 2004 (Continued)

\begin{tabular}{lll} 
Bias & Authors' judgement & Support for judgement \\
\hline $\begin{array}{l}\text { Random sequence genera- } \\
\text { tion (selection bias) }\end{array}$ & High risk & Allocated on the basis of hospital number \\
\hline
\end{tabular}

tion (selection bias)

Allocation concealment High risk $\quad$ Sequence generated by hospital number
(selection bias)

(selection bias)

High risk Blinding of care provider: no

Blinding (performance

bias and detection bias)

Acute nausea

Blinding of participant: no

Blinding of outcome assessors: no

Blinding (performance
bias and detection bias)

High risk

Blinding of care provider: no

Acute vomiting

Blinding of participant: no

Blinding of outcome assessors: no

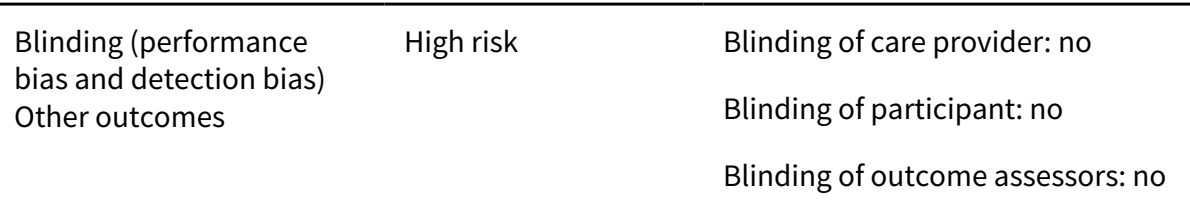

Incomplete outcome data Low risk No loss to follow-up

(attrition bias)

All outcomes

Selective reporting (re- $\quad$ Low risk
porting bias)

\begin{tabular}{ll}
\hline Other bias $\quad$ Low risk $\quad$ No other risk of bias noted \\
\hline
\end{tabular}

Komada 1999

\begin{tabular}{ll}
\hline Methods & $\begin{array}{l}\text { RCT } \\
\text { Cross-over }\end{array}$ \\
\hline Participants & $\begin{array}{l}\text { Participants with ALL receiving either high-dose methotrexate }\left(3 \mathrm{~g} / \mathrm{m}^{2}\right) \text { or high-dose cytarabine plus } \\
\text { dexamethasone }\left(3 \mathrm{~g} / \mathrm{m}^{2}\right) . \text { Participants aged } 6.3 \text { years (range } 1 \text { year to } 14 \text { years), 21/49 male }\end{array}$ \\
\hline Interventions & Granisetron $20 \mathrm{mcg} / \mathrm{kg}$ given immediately prior to chemotherapy at 30 min IV infusion \\
\hline Outcomes & Episodes of vomiting recorded \\
\hline Notes & $\begin{array}{l}13 \text { participants receiving Ara-C had their treatment 'contaminated' by the concurrent use of dexam- } \\
\text { ethasone as an antiemetic }\end{array}$ \\
\hline
\end{tabular}

\section{Risk of bias}

Bias Authors' judgement Support for judgement


Komada 1999 (Continued)

\begin{tabular}{lll}
$\begin{array}{l}\text { Random sequence genera- } \\
\text { tion (selection bias) }\end{array}$ & Unclear risk & Not stated \\
\hline $\begin{array}{l}\text { Allocation concealment } \\
\text { (selection bias) }\end{array}$ & Unclear risk & Not stated \\
\hline $\begin{array}{l}\text { Blinding (performance } \\
\text { bias and detection bias) } \\
\begin{array}{l}\text { Acute nausea } \\
\end{array}\end{array}$ & High risk & Blinding of care provider: no \\
& Blinding of participant: no
\end{tabular}

\begin{tabular}{|c|c|c|}
\hline $\begin{array}{l}\text { Blinding (performance } \\
\text { bias and detection bias) } \\
\text { Acute vomiting }\end{array}$ & High risk & Not reported \\
\hline $\begin{array}{l}\text { Blinding (performance } \\
\text { bias and detection bias) } \\
\text { Other outcomes }\end{array}$ & High risk & Not reported \\
\hline $\begin{array}{l}\text { Incomplete outcome data } \\
\text { (attrition bias) } \\
\text { All outcomes }\end{array}$ & Low risk & No dropouts in 24-hour data, all completed cross-over \\
\hline $\begin{array}{l}\text { Selective reporting (re- } \\
\text { porting bias) }\end{array}$ & Low risk & Unclear if the HD-MTX and high-dose Ara-C were identified a priori \\
\hline
\end{tabular}

Kurucu 2012

\begin{tabular}{ll}
\hline Methods & RCT \\
\hline Participants & $\begin{array}{l}18 \text { children (aged } 35 \text { to } 207 \text { months) receiving chemotherapy including at least } 1 \text { highly emetogenic } \\
\text { drug. A total of } 70 \text { courses were studied }\end{array}$ \\
\hline Interventions & 36 courses - participants received ondansetron $5 \mathrm{mg} / \mathrm{m}^{2}$ \\
\hline Outcomes & 34 courses - participants received ondansetron $5 \mathrm{mg} / \mathrm{m}^{2} \mathrm{plus} \mathrm{hydroxyzine} 1 \mathrm{mg} / \mathrm{kg}$ \\
& Control of emesis using Skoup-Smith criteria (Skoup 1990; Smith 1990) \\
& Degree of symptoms using Symptom Distress Scale (McCorcle 1998)
\end{tabular}

Notes

\section{Risk of bias}

\section{Bias}

Random sequence genera-

tion (selection bias)

\section{Authors' judgement Support for judgement}

No details 
Kurucu 2012 (Continued)

\begin{tabular}{lll}
$\begin{array}{l}\text { Allocation concealment } \\
\text { (selection bias) }\end{array}$ & Unclear risk & No details \\
\hline $\begin{array}{l}\text { Blinding (performance } \\
\text { bias and detection bias) } \\
\begin{array}{l}\text { Acute nausea } \\
\text { nigh risk }\end{array}\end{array}$ & $\begin{array}{l}\text { Placebo not used; hydroxyzine given regularly (orally) throughout chemother- } \\
\text { apy course; participants, caregivers, and observers would be aware of addi- } \\
\text { tional drug being given }\end{array}$ \\
\hline
\end{tabular}

\begin{tabular}{|c|c|c|}
\hline $\begin{array}{l}\text { Blinding (performance } \\
\text { bias and detection bias) } \\
\text { Acute vomiting }\end{array}$ & High risk & $\begin{array}{l}\text { Placebo not used; hydroxyzine given regularly (orally) throughout chemother- } \\
\text { apy course; participants, caregivers, and observers would be aware of addi- } \\
\text { tional drug being given }\end{array}$ \\
\hline
\end{tabular}

\begin{tabular}{|c|c|c|}
\hline $\begin{array}{l}\text { Blinding (performance } \\
\text { bias and detection bias) } \\
\text { Other outcomes }\end{array}$ & High risk & $\begin{array}{l}\text { Placebo not used; hydroxyzine given regularly (orally) throughout chemother- } \\
\text { apy course; participants, caregivers, and observers would be aware of addi- } \\
\text { tional drug being given }\end{array}$ \\
\hline
\end{tabular}

\begin{tabular}{lll}
\hline $\begin{array}{l}\text { Incomplete outcome data } \\
\text { (attrition bias) } \\
\text { All outcomes }\end{array}$ & Low risk & All participants accounted for \\
\hline $\begin{array}{l}\text { Selective reporting (re- } \\
\text { porting bias) }\end{array}$ & Low risk & All outcomes reported \\
\hline Other bias & Low risk & No other risk of bias noted \\
\hline
\end{tabular}

\section{Mabro 2000}

\begin{tabular}{|c|c|}
\hline Methods & $\mathrm{RCT}$ \\
\hline Participants & $\begin{array}{l}\text { Any patients with paediatric malignancy excluding cerebral tumours associated with vomiting } \\
\text { Receiving moderately emetogenic chemotherapy: } \\
\text { - carboplatin }\left(>=500 \mathrm{mg} / \mathrm{m}^{2}\right) \\
\text { - cyclophosphamide }\left(>=500 \text { to } 900 \mathrm{mg} / \mathrm{m}^{2}\right) \text { in combination with other agents } \\
\text { - ifosfamide }\left(1 \mathrm{to} 2.4 \mathrm{~g} / \mathrm{m}^{2}\right) \\
\text { - actinomycin } D\left(>=1.5 \mathrm{mg} / \mathrm{m}^{2}\right) \\
\left.\text { - cisplatin ( } 20 \text { to } 49 \mathrm{mg} / \mathrm{m}^{2}\right) \\
\text { - methotrexate }\left(>8 \mathrm{~g} / \mathrm{m}^{2}\right) \\
\text { - adriamycin }\left(>=60 \mathrm{mg} / \mathrm{m}^{2}\right) \\
\text { - cytarabine }\left(1 \text { to } 2.9 \mathrm{~g} / \mathrm{m}^{2}\right) \\
\text { OR highly emetogenic chemotherapy: } \\
\text { - cyclophosphamide }\left(>=1000 \mathrm{mg} / \mathrm{m}^{2}\right) \\
\text { - cisplatin }\left(>=50 \mathrm{mg} / \mathrm{m}^{2}\right) \\
\text { - ifosfamide }\left(>=2.5 \mathrm{~g} / \mathrm{m}^{2}\right) \\
\text { - nitrogen mustard }\left(>6 \mathrm{mg} / \mathrm{m}^{2}\right) \\
\text { - dacarbazine }\left(>200 \mathrm{mg} / \mathrm{m}^{2}\right) \\
\text { - cytarabine }\left(>=3 \mathrm{~g} / \mathrm{m}^{2}\right) \\
\text { Patients were excluded if: received more than } 1 \text { course of chemotherapy in preceding year, radiation } \\
\text { therapy in preceding } 7 \mathrm{days} \text { or during course of study, emetogenic chemotherapy in preceding } 7 \text { days, } \\
\text { persistent nausea or vomiting in preceding } 48 \text { hours, a food intolerance in preceding } 4 \text { days, intestinal } \\
\text { obstruction, corticosteroids outside of chemotherapy treatment, other antiemetic treatments, cerebral } \\
\text { tumours associated with vomiting, liver enzymes outside of specified range }\end{array}$ \\
\hline
\end{tabular}


Mabro 2000 (Continued)

Mean age 7.8 years (range 1 year to 16 years). 177/294 participants were male

Interventions

143 participants received $20 \mu \mathrm{g} / \mathrm{kg}$ oral granisetron (orange flavoured) - diluted to $0.2 \mathrm{mg} / \mathrm{ml}$ and given 1 hour before and again 6 to 12 hours after the start of chemotherapy on each day of chemotherapy for 1 to 5 days (depending on chemotherapy regimen)

151 participants received $40 \mu \mathrm{g} / \mathrm{kg}$ oral granisetron (orange flavoured) - diluted to $0.2 \mathrm{mg} / \mathrm{ml}$ and given 1 hour before and again 6 to 12 hours after the start of chemotherapy on each day of chemotherapy for 1 to 5 days (depending on chemotherapy regimen)

Outcomes Number of vomits recorded every 6 hours for each 24-hour period. Nausea assessed by unvalidated self/parent report using a scale of "none, mild, moderate, severe"

Notes $-\quad$

\section{Risk of bias}

\begin{tabular}{|c|c|c|}
\hline Bias & Authors' judgement & Support for judgement \\
\hline $\begin{array}{l}\text { Random sequence genera- } \\
\text { tion (selection bias) }\end{array}$ & Unclear risk & States "randomised" \\
\hline $\begin{array}{l}\text { Allocation concealment } \\
\text { (selection bias) }\end{array}$ & Unclear risk & Not stated \\
\hline $\begin{array}{l}\text { Blinding (performance } \\
\text { bias and detection bias) } \\
\text { Acute nausea }\end{array}$ & High risk & Not reported \\
\hline $\begin{array}{l}\text { Blinding (performance } \\
\text { bias and detection bias) } \\
\text { Acute vomiting }\end{array}$ & Low risk & $\begin{array}{l}\text { States "double blind" } \\
\text { Blinding of care provider: yes } \\
\text { Blinding of participant: yes } \\
\text { Blinding of outcome assessors: yes }\end{array}$ \\
\hline $\begin{array}{l}\text { Blinding (performance } \\
\text { bias and detection bias) } \\
\text { Other outcomes }\end{array}$ & Low risk & $\begin{array}{l}\text { States "double blind" } \\
\text { Blinding of care provider: yes } \\
\text { Blinding of participant: yes } \\
\text { Blinding of outcome assessors: yes }\end{array}$ \\
\hline
\end{tabular}

Incomplete outcome data Low risk Intention-to-treat analysis reported by day
(attrition bias)

All outcomes

Selective reporting (re- Low risk $\quad-$
porting bias)
porting bias)

Other bias Low risk Randomisation stratified by emetogenic level of chemotherapy

Methods RCT


Marshall 1989 (Continued)

Cross-over

Participants

Any child with a paediatric malignancy on any chemotherapy protocol including BMT conditioning in 6 participants, who had a second course planned. Median age 7 years ( 4 to 15 years), with $17 / 26$ male

$\begin{array}{ll}\text { Interventions } & \text { Chlorpromazine } 0.825 \mathrm{mg} / \mathrm{kg} \text { QDS IV for } 4 \text { doses } \\ \text { Cocktail. Metoclopramide (IV) } 2 \mathrm{mg} / \mathrm{kg} / \mathrm{dose} 0,2,6,12 \text { hours. Dexamethasone (IV) } 0.7 \mathrm{mg} / \mathrm{kg} 0 \text { hours. } \\ \text { Benzatropine (IV) } 0.02 \mathrm{mg} / \mathrm{kg} / \text { dose } 0,6 \text { hours. Lorazepam (PO) } 0.05 \mathrm{mg} / \mathrm{kg} / \mathrm{dose}, 1 \text { hour and } 12 \mathrm{hours}\end{array}$

Outcomes Recorded number and duration of vomiting using ?structured interview - unclear

Notes - -

\section{Risk of bias}

\begin{tabular}{|c|c|c|}
\hline Bias & Authors' judgement & Support for judgement \\
\hline $\begin{array}{l}\text { Random sequence genera- } \\
\text { tion (selection bias) }\end{array}$ & Unclear risk & Not stated \\
\hline $\begin{array}{l}\text { Allocation concealment } \\
\text { (selection bias) }\end{array}$ & Unclear risk & Not stated \\
\hline $\begin{array}{l}\text { Blinding (performance } \\
\text { bias and detection bias) } \\
\text { Acute nausea }\end{array}$ & Unclear risk & Not reported \\
\hline $\begin{array}{l}\text { Blinding (performance } \\
\text { bias and detection bias) } \\
\text { Acute vomiting }\end{array}$ & Unclear risk & $\begin{array}{l}\text { "Double blinded" but unclear how effective the placebos would be } \\
\text { Blinding of care provider: unclear } \\
\text { Blinding of participant: unclear } \\
\text { Blinding of outcome assessors: unclear }\end{array}$ \\
\hline $\begin{array}{l}\text { Blinding (performance } \\
\text { bias and detection bias) } \\
\text { Other outcomes }\end{array}$ & Unclear risk & Not reported \\
\hline $\begin{array}{l}\text { Incomplete outcome data } \\
\text { (attrition bias) } \\
\text { All outcomes }\end{array}$ & Unclear risk & $2 / 26$ did not complete the cross-over \\
\hline $\begin{array}{l}\text { Selective reporting (re- } \\
\text { porting bias) }\end{array}$ & Low risk & - \\
\hline Other bias & Unclear risk & $\begin{array}{l}6 / 26 \text { on conditioning regimens given after } 24 \text { hours - could there be a car- } \\
\text { ry-over effect? }\end{array}$ \\
\hline
\end{tabular}

\section{Mehta 1986}

\begin{tabular}{ll}
\hline Methods & RCT \\
\hline Participants & $\begin{array}{l}20 \text { children with paediatric malignancy who had any chemotherapy containing adriamycin }>30 \mathrm{mg} / \mathrm{m}^{2}, \\
\text { cisplat }>100 \mathrm{mg} / \mathrm{m}^{2}, \mathrm{MTX}>300 \mathrm{mg} / \mathrm{m}^{2}, \text { actinoD }>0.5 \mathrm{mg} / \mathrm{m}^{2}, \text { cyclo }>1 \mathrm{~g} / \mathrm{m}^{2} \text { or lomustine }>6 \mathrm{mg} / \mathrm{m}^{2}, \\
\text { and had experienced significant toxicity on a previous course. Gender not specified }\end{array}$ \\
\hline
\end{tabular}

Antiemetic medication for prevention and treatment of chemotherapy-induced nausea and vomiting in childhood (Review) 
Mehta 1986 (Continued)
Interventions
10 participants received chlorpromazine $0.5 \mathrm{mg} / \mathrm{kg}$ IV 30 minutes prior to chemotherapy

10 participants received methylprednisolone $4 \mathrm{mg} / \mathrm{kg}$ IV 30 minutes prior to chemotherapy

Outcomes $\begin{aligned} & \text { Unvalidated assessment of nausea by clinicians for the first } 2 \text { to } 8 \text { hours, then parental/participant re- } \\ & \text { port. Duration of nausea and number of vomiting episodes recorded }\end{aligned}$

port. Duration of nausea and number of vomiting episodes recorded

Notes $\quad-$

\section{Risk of bias}

\begin{tabular}{|c|c|c|}
\hline Bias & Authors' judgement & Support for judgement \\
\hline $\begin{array}{l}\text { Random sequence genera- } \\
\text { tion (selection bias) }\end{array}$ & Unclear risk & Not stated \\
\hline $\begin{array}{l}\text { Allocation concealment } \\
\text { (selection bias) }\end{array}$ & Unclear risk & Not stated \\
\hline \multirow{4}{*}{$\begin{array}{l}\text { Blinding (performance } \\
\text { bias and detection bias) } \\
\text { Acute nausea }\end{array}$} & Low risk & "Double blinded" \\
\hline & & Blinding of care provider: yes \\
\hline & & Blinding of participant: yes \\
\hline & & Blinding of outcome assessors: yes \\
\hline \multirow{4}{*}{$\begin{array}{l}\text { Blinding (performance } \\
\text { bias and detection bias) } \\
\text { Acute vomiting }\end{array}$} & High risk & "Double blinded" \\
\hline & & Blinding of care provider: yes \\
\hline & & Blinding of participant: yes \\
\hline & & Blinding of outcome assessors: yes \\
\hline \multirow{4}{*}{$\begin{array}{l}\text { Blinding (performance } \\
\text { bias and detection bias) } \\
\text { Other outcomes }\end{array}$} & High risk & "Double blinded" \\
\hline & & Blinding of care provider: yes \\
\hline & & Blinding of participant: yes \\
\hline & & Blinding of outcome assessors: yes \\
\hline $\begin{array}{l}\text { Incomplete outcome data } \\
\text { (attrition bias) } \\
\text { All outcomes }\end{array}$ & High risk & $\begin{array}{l}3 \text { not evaluated, unclear from which arm or even if excluded prior to randomi- } \\
\text { sation }\end{array}$ \\
\hline $\begin{array}{l}\text { Selective reporting (re- } \\
\text { porting bias) }\end{array}$ & Low risk & - \\
\hline Other bias & Low risk & No other risk of bias noted \\
\hline
\end{tabular}

Mehta 1997

\begin{tabular}{ll}
\hline Methods & RCT \\
\hline
\end{tabular}


Mehta 1997 (Continued)

Participants

28 participants with need for stem cell (bone marrow) transplantation (allograft or autologous), including those receiving TBI. Median age 8 years (range 4 to 12 years), 9/15 male in ondansetron group. Median age 9.5 years (range 4 to 17 ), $9 / 13$ male in perphenazine group.

\begin{tabular}{ll}
\hline Interventions & $\begin{array}{l}15 \text { participants received ondansetron loading } 0.15 \mathrm{mg} / \mathrm{kg} \text { then } 0.45 \mathrm{mg} / \mathrm{kg} \text { as continuous infusion } \\
13 \text { participants received perphenazine } 0.06 \mathrm{mg} / \mathrm{kg} \text { loading and } 0.4 \mathrm{mg} / \mathrm{kg} \text { per } 24 \text { hours continuous infu- } \\
\text { sion), plus diphenhydramine } 1 \mathrm{mg} / \mathrm{kg} \text { QDS }\end{array}$ \\
\hline Outcomes & $\begin{array}{l}\text { "Continuous" recording of vomiting and retching (events within } 5 \text { minutes considered as a single } \\
\text { episode). Probably nursing staff recording outcomes }\end{array}$ \\
\hline Notes & -
\end{tabular}

\section{Risk of bias}

\begin{tabular}{|c|c|c|}
\hline Bias & Authors' judgement & Support for judgement \\
\hline $\begin{array}{l}\text { Random sequence genera- } \\
\text { tion (selection bias) }\end{array}$ & Unclear risk & Not stated \\
\hline $\begin{array}{l}\text { Allocation concealment } \\
\text { (selection bias) }\end{array}$ & Unclear risk & Not stated \\
\hline $\begin{array}{l}\text { Blinding (performance } \\
\text { bias and detection bias) } \\
\text { Acute nausea }\end{array}$ & High risk & Not reported \\
\hline $\begin{array}{l}\text { Blinding (performance } \\
\text { bias and detection bias) } \\
\text { Acute vomiting }\end{array}$ & High risk & Not reported \\
\hline $\begin{array}{l}\text { Blinding (performance } \\
\text { bias and detection bias) } \\
\text { Other outcomes }\end{array}$ & High risk & $\begin{array}{l}\text { Blinding of care provider: no } \\
\text { Blinding of participant: no } \\
\text { Blinding of outcome assessors: no }\end{array}$ \\
\hline $\begin{array}{l}\text { Incomplete outcome data } \\
\text { (attrition bias) } \\
\text { All outcomes }\end{array}$ & High risk & $\begin{array}{l}3 \text { not evaluated, unclear from which arm or even if excluded prior to randomi- } \\
\text { sation }\end{array}$ \\
\hline $\begin{array}{l}\text { Selective reporting (re- } \\
\text { porting bias) }\end{array}$ & Low risk & - \\
\hline Other bias & Low risk & No other risk of bias noted \\
\hline
\end{tabular}

Nagel 2008

\begin{tabular}{ll}
\hline Methods & RCT cross-over trial \\
\hline Participants & 25 participants aged 4 to 17 years with newly diagnosed ALL \\
\hline Interventions & Placebo + placebo \\
& Fentanyl $1 \mathrm{mg} / \mathrm{kg}+$ placebo
\end{tabular}

Antiemetic medication for prevention and treatment of chemotherapy-induced nausea and vomiting in childhood (Review) 
Nagel 2008 (Continued)

Placebo + ondansetron $0.15 \mathrm{mg} / \mathrm{kg}$

Fentanyl $1 \mathrm{mg} / \mathrm{kg}$ + ondansetron $0.15 \mathrm{mg} / \mathrm{kg}$

Number of vomits
Severity of nausea (reported by parents based on disruption of daily activity)
Severity of pain (reported using Wong-Baker FACES)
Use of antiemetics
Use of analgesia

Notes

\section{Risk of bias}

\begin{tabular}{|c|c|c|}
\hline Bias & Authors' judgement & Support for judgement \\
\hline $\begin{array}{l}\text { Random sequence genera- } \\
\text { tion (selection bias) }\end{array}$ & Unclear risk & States randomised but details not provided \\
\hline $\begin{array}{l}\text { Allocation concealment } \\
\text { (selection bias) }\end{array}$ & Unclear risk & Not stated \\
\hline $\begin{array}{l}\text { Blinding (performance } \\
\text { bias and detection bias) } \\
\text { Acute nausea }\end{array}$ & Low risk & Double-blind, placebo used \\
\hline $\begin{array}{l}\text { Blinding (performance } \\
\text { bias and detection bias) } \\
\text { Acute vomiting }\end{array}$ & Low risk & Double-blind, placebo used \\
\hline $\begin{array}{l}\text { Blinding (performance } \\
\text { bias and detection bias) } \\
\text { Other outcomes }\end{array}$ & Low risk & Double-blind, placebo used \\
\hline
\end{tabular}

Incomplete outcome data High risk 11 of 24 participants did not complete all 4 trial arms
(attrition bias)
All outcomes

Selective reporting (re- Low risk All outcomes reported
porting bias)

Other bias Unclear risk $\quad$ Paired data not provided

\section{Noguera 2001}

$\begin{array}{ll}\text { Methods } & \text { RCT } \\ \text { Randomised per course, but multiple episodes per participant }\end{array}$

Participants

Participants with 6 different neoplasms: ALL, Wilms, brain, rhabdomyosarcoma, ovarian germ cell, and retinoblastoma, who received highly or very highly emetogenic chemotherapy (cisplatin, high-dose carboplatin, high-dose cyclophosphamide, high-dose methotrexate, or daunorubicin). Median age 6 years ( 3 months to 14 years), 6/12 participants were male 
Noguera 2001 (Continued)

Ondansetron $0.45 \mathrm{mg} / \mathrm{kg}$ IV 15 minutes after chemotherapy
Tropisetron $0.20 \mathrm{mg} / \mathrm{kg}$ IV 15 minutes after chemotherapy
Granisetron $20 \mu \mathrm{g} / \mathrm{kg}$ IV 15 minutes after chemotherapy

\begin{tabular}{ll}
\hline Outcomes & Number of vomiting episodes recorded by nurses in charge of care \\
\hline Notes & Translation and extraction by Moacyr Nobre, InCor HCFMUSP, São Paulo, Brazil
\end{tabular}

\section{Risk of bias}

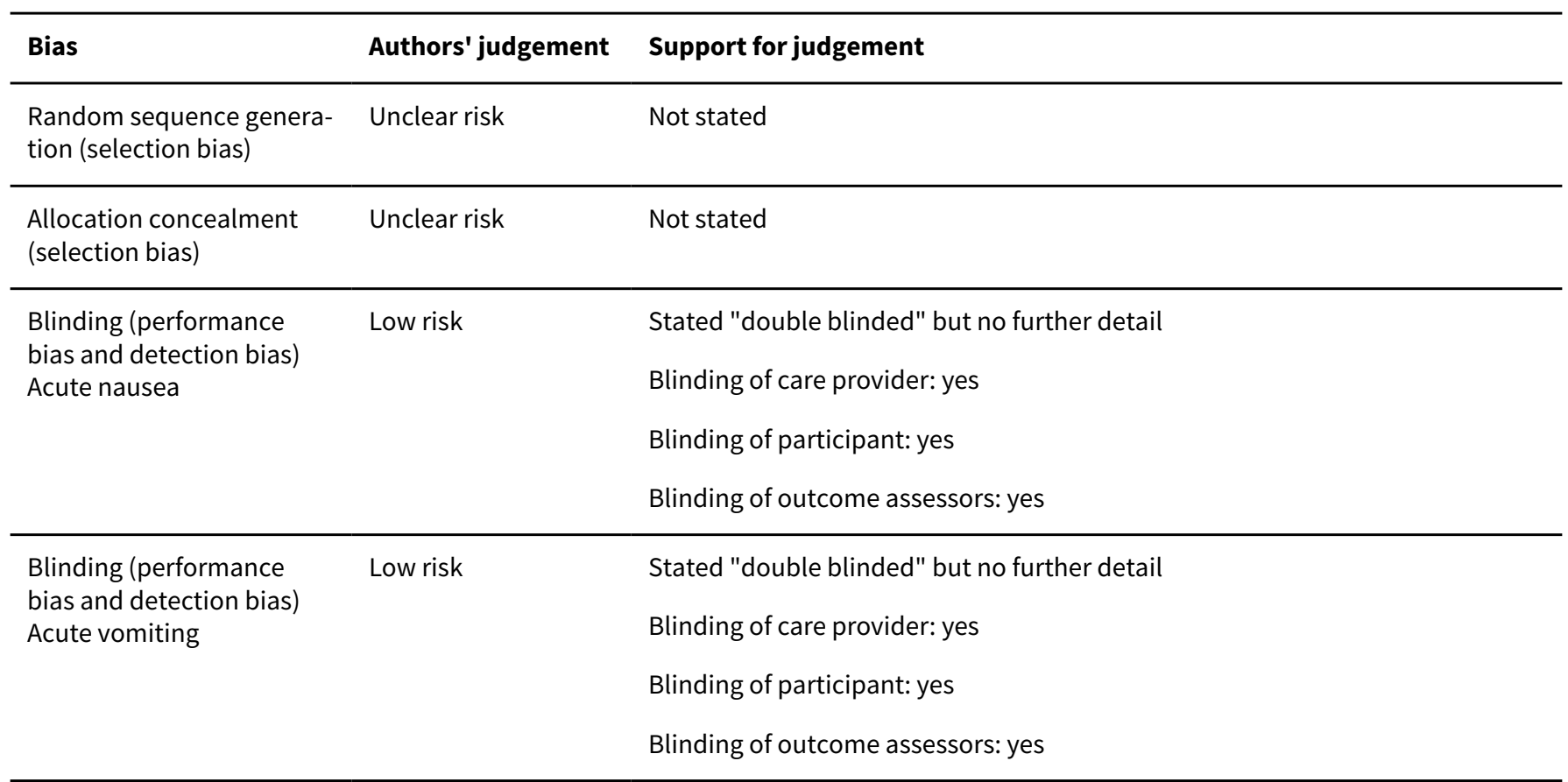

$\begin{array}{lll}\text { Blinding (performance } & \text { High risk } & \text { Not reported } \\ \text { bias and detection bias) } & \end{array}$

Other outcomes

\begin{tabular}{lll}
$\begin{array}{l}\text { Incomplete outcome data } \\
\text { (attrition bias) } \\
\text { All outcomes }\end{array}$ & High risk & 11 episodes in total ( $15 \%)$ missing data - not clear out of which groups \\
\hline $\begin{array}{l}\text { Selective reporting (re- } \\
\text { porting bias) }\end{array}$ & Unclear risk & Could not be determined \\
\hline Other bias & Low risk & No other risk of bias noted \\
\hline
\end{tabular}

Orchard 1999

\begin{tabular}{ll}
\hline Methods & RCT \\
\hline Participants & $\begin{array}{l}187 \text { paediatric patients (not all had malignancy) receiving any of the standard conditioning regimens } \\
\text { (chemotherapy alone or with TBI) for autologous or allogeneic BMT. Age ranged from } 2 \text { to } 16 \text { years. Gen- } \\
\text { der split not given }\end{array}$ \\
\hline
\end{tabular}


Orchard 1999 (Continued)

Interventions

90 participants received granisetron: $10 \mathrm{mcg} / \mathrm{kg} / \mathrm{dose}$ before start of chemo/TBI then every 12 hours, and placebo: continuous infusion $5 \%$ dextrose (until day of transplant - day 0 )

97 participants received ondansetron: loading dose $0.15 \mathrm{mg} / \mathrm{kg}$ before start of chemo/TBI then continuous infusion $0.03 \mathrm{mg} / \mathrm{kg} /$ hour rounded to nearest $0.1 \mathrm{mg}$ (until day of transplant - day 0), and placebo: intermittent $5 \%$ dextrose administered every 12 hours

All participants: dexamethasone $10 \mathrm{mg} / \mathrm{m}^{2} /$ day $(\max 10 \mathrm{mg}$ ). For breakthrough nausea/vomiting, lorazepam $0.05 \mathrm{mg} / \mathrm{kg}$ IV or promethazine 0.25 to $1.0 \mathrm{mg} / \mathrm{kg}$ IV every 4 to 6 hours. Other antiemetic support was considered as needed

\begin{tabular}{ll}
\hline Outcomes & Child recorded nausea using an unvalidated 'faces' approach (nausea VAS: smiling/frowning faces) \\
& Nurse recorded episodes of vomiting \\
\hline Notes & $\begin{array}{l}73 \% \text { of participants had TBI in addition to conditioning chemotherapy } \\
\text { Authors provided additional graphical data showing the changes in nausea scores and episodes of } \\
\text { vomiting in children over time }\end{array}$
\end{tabular}

\section{Risk of bias}

\begin{tabular}{lll}
\hline Bias & Authors' judgement & Support for judgement \\
\hline $\begin{array}{l}\text { Random sequence genera- } \\
\text { tion (selection bias) }\end{array}$ & Low risk & States randomised, but no further details given \\
\hline $\begin{array}{l}\text { Allocation concealment } \\
\text { (selection bias) }\end{array}$ & Unclear risk & Not stated \\
\hline $\begin{array}{l}\text { Blinding (performance } \\
\text { bias and detection bias) } \\
\text { Acute nausea }\end{array}$ & Low risk & States double-blind. Placebo used. \\
& Blinding of care provider: yes \\
& Blinding of participant: yes \\
& Blinding of outcome assessors: yes
\end{tabular}

\begin{tabular}{|c|c|c|}
\hline $\begin{array}{l}\text { Blinding (performance } \\
\text { bias and detection bias) } \\
\text { Acute vomiting }\end{array}$ & Low risk & $\begin{array}{l}\text { States double-blind. Placebo used. } \\
\text { Blinding of care provider: yes } \\
\text { Blinding of participant: yes } \\
\text { Blinding of outcome assessors: yes }\end{array}$ \\
\hline $\begin{array}{l}\text { Blinding (performance } \\
\text { bias and detection bias) } \\
\text { Other outcomes }\end{array}$ & High risk & Not reported \\
\hline
\end{tabular}

Incomplete outcome data Low risk No withdrawals/dropouts confirmed by author
(attrition bias)

(attrition bias)
All outcomes

\begin{tabular}{lll}
\hline $\begin{array}{l}\text { Selective reporting (re- } \\
\text { porting bias) }\end{array}$ & Low risk & - \\
\hline Other bias & Low risk & $\begin{array}{l}\text { Potentially: } 73 \% \text { of participants had TBI in addition to conditioning } \\
\text { chemotherapy }\end{array}$ \\
\hline
\end{tabular}

Antiemetic medication for prevention and treatment of chemotherapy-induced nausea and vomiting in childhood (Review) Copyright $\odot 2016$ The Cochrane Collaboration. Published by John Wiley \& Sons, Ltd. 
Parker 2001

\begin{tabular}{ll} 
Methods & $\begin{array}{l}\text { RCT } \\
\text { Cross-over }\end{array}$ \\
\hline Participants & $\begin{array}{l}\text { Participants with ALL receiving intrathecal chemotherapy +/- maintenance chemotherapy. Median age } \\
6 \text { years (range } 2 \text { to } 17 \text { years). } 12 / 26 \text { were male }\end{array}$ \\
\hline Interventions & $\begin{array}{l}\text { High-dose ondansetron } 0.45 \mathrm{mg} / \mathrm{kg} \mathrm{IV} 15 \text {-minute infusion } 30 \text { minutes prior to lumbar puncture } \\
\text { Low-dose ondansetron } 0.15 \mathrm{mg} / \mathrm{kg} \text { IV } 15 \text {-minute infusion } 30 \text { minutes prior to lumbar puncture }\end{array}$ \\
\hline Placebo (saline) IV 15 -minute infusion 30 minutes prior to lumbar puncture \\
\hline Potes & $\begin{array}{l}\text { Parental report of number of vomiting episodes recorded } \\
\text { than of chemotherapy-induced emesis }\end{array}$ \\
\hline
\end{tabular}

\section{Risk of bias}

\begin{tabular}{|c|c|c|}
\hline Bias & Authors' judgement & Support for judgement \\
\hline $\begin{array}{l}\text { Random sequence genera- } \\
\text { tion (selection bias) }\end{array}$ & Unclear risk & Not stated \\
\hline $\begin{array}{l}\text { Allocation concealment } \\
\text { (selection bias) }\end{array}$ & Unclear risk & Not stated \\
\hline $\begin{array}{l}\text { Blinding (performance } \\
\text { bias and detection bias) } \\
\text { Acute nausea }\end{array}$ & High risk & Not reported \\
\hline $\begin{array}{l}\text { Blinding (performance } \\
\text { bias and detection bias) } \\
\text { Acute vomiting }\end{array}$ & Low risk & $\begin{array}{l}\text { States double-blind. No further details. } \\
\text { Blinding of care provider: yes } \\
\text { Blinding of participant: yes } \\
\text { Blinding of outcome assessors: yes }\end{array}$ \\
\hline $\begin{array}{l}\text { Blinding (performance } \\
\text { bias and detection bias) } \\
\text { Other outcomes }\end{array}$ & High risk & Not reported \\
\hline $\begin{array}{l}\text { Incomplete outcome data } \\
\text { (attrition bias) } \\
\text { All outcomes }\end{array}$ & High risk & $\begin{array}{l}\text { Dropouts between cross-overs ( } 1 \text { before placebo, } 2 \text { before ondansetron } 0.45 \\
\mathrm{mg} / \mathrm{kg} \text { ) }\end{array}$ \\
\hline $\begin{array}{l}\text { Selective reporting (re- } \\
\text { porting bias) }\end{array}$ & Low risk & - \\
\hline Other bias & Low risk & No other risk of bias noted \\
\hline
\end{tabular}


Safonova 1999

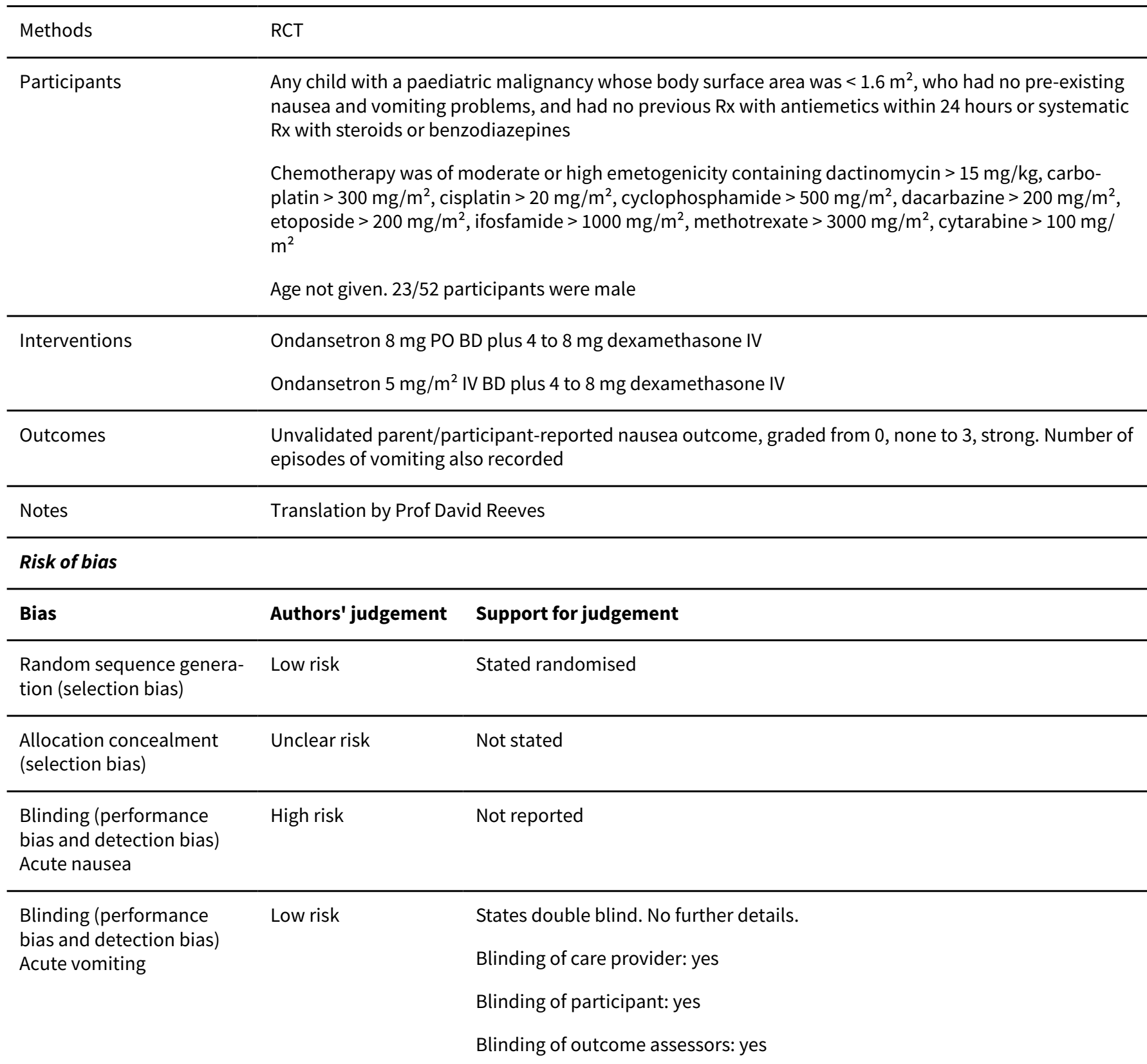

\begin{tabular}{lll}
\hline $\begin{array}{l}\text { Blinding (performance } \\
\text { bias and detection bias) } \\
\text { Other outcomes }\end{array}$ & High risk & Not reported \\
\hline $\begin{array}{l}\text { Incomplete outcome data } \\
\begin{array}{l}\text { (attrition bias) } \\
\text { All outcomes }\end{array}\end{array}$ & Low risk & No loss of participants \\
\hline $\begin{array}{l}\text { Selective reporting (re- } \\
\text { porting bias) }\end{array}$ & Low risk & - \\
\hline Other bias & Low risk & No other risk of bias noted \\
\hline
\end{tabular}


Sandoval 1999

\begin{tabular}{|c|c|}
\hline Methods & RCT \\
\hline \multirow[t]{4}{*}{ Participants } & $\begin{array}{l}\text { Any newly diagnosed patient with malignancy undergoing moderately or highly emetogenic } \\
\text { chemotherapy }\end{array}$ \\
\hline & $\begin{array}{l}\text { Moderately: anthracyclines } 25 \text { to } 60 \mathrm{mg} / \mathrm{m}^{2} \text {, carboplatin } 175 \mathrm{mg} / \mathrm{m}^{2} \text {, cyclophosphamide } 1200 \text { to } 1500 \\
\mathrm{mg} / \mathrm{m}^{2} \text {, and etoposide } 100 \mathrm{mg} / \mathrm{m}^{2}\end{array}$ \\
\hline & $\begin{array}{l}\text { Highly: cisplatin } 100 \mathrm{mg} / \mathrm{m}^{2} \text {, cyclophosphamide }>1500 \mathrm{mg} / \mathrm{m}^{2} \text {, dacarbazine } 375 \mathrm{mg} / \mathrm{m}^{2} \text {, and actino- } \\
\text { mycin } 1.35 \mathrm{mg} / \mathrm{m}^{2}\end{array}$ \\
\hline & Median age 4 years (range 0.25 to 18 years) with $16 / 31$ participants male \\
\hline Interventions & $\begin{array}{l}16 \text { participants received ondansetron } 0.6 \mathrm{mg} / \mathrm{kg} \text { ( } \max 32 \mathrm{mg} \text { ) IV over } 30 \text { minutes before chemotherapy } \\
\text { then } 3 \text { normal saline doses given every } 4 \text { hours starting } 4 \text { hours after ondansetron }\end{array}$ \\
\hline \multirow[t]{6}{*}{ Outcomes } & Unvalidated nausea assessment tool, unclear who recorded nausea. Scaled: \\
\hline & 1. No nausea or emesis \\
\hline & 2. Nauseous but able to eat \\
\hline & 3. Nauseous and unable to eat \\
\hline & 4. Emesis \\
\hline & Number of vomiting episodes and time-to-first-vomit were recorded \\
\hline
\end{tabular}

\section{Notes}

\section{Risk of bias}

\begin{tabular}{|c|c|c|}
\hline Bias & Authors' judgement & Support for judgement \\
\hline $\begin{array}{l}\text { Random sequence genera- } \\
\text { tion (selection bias) }\end{array}$ & Low risk & Pharmacist not involved in participant care using a random number table \\
\hline $\begin{array}{l}\text { Allocation concealment } \\
\text { (selection bias) }\end{array}$ & Low risk & Allocation by pharmacist not involved with participant care \\
\hline \multirow[t]{3}{*}{$\begin{array}{l}\text { Blinding (performance } \\
\text { bias and detection bias) } \\
\text { Acute nausea }\end{array}$} & Low risk & States double-blind. No further details. \\
\hline & & Blinding of participant: yes \\
\hline & & Blinding of outcome assessors: yes \\
\hline \multirow{4}{*}{$\begin{array}{l}\text { Blinding (performance } \\
\text { bias and detection bias) } \\
\text { Acute vomiting }\end{array}$} & Low risk & States double-blind. No further details. \\
\hline & & Blinding of care provider: yes \\
\hline & & Blinding of participant: yes \\
\hline & & Blinding of outcome assessors: yes \\
\hline
\end{tabular}

Blinding (performance Low risk

bias and detection bias)

Other outcomes

\author{
States double-blind. No further details. \\ Blinding of care provider: yes \\ Blinding of participant: yes
}


Sandoval 1999 (Continued)

Blinding of outcome assessors: yes

\begin{tabular}{lll}
\hline $\begin{array}{l}\text { Incomplete outcome data } \\
\text { (attrition bias) } \\
\text { All outcomes }\end{array}$ & High risk & No loss of participants \\
\hline $\begin{array}{l}\text { Selective reporting (re- } \\
\text { porting bias) }\end{array}$ & Low risk & - \\
\hline $\begin{array}{l}\text { Other bias } \\
\text { Unclear risk }\end{array}$ & $\begin{array}{l}\text { Multi-dose group had } 7 / 15(47 \%) \text { highly emetogenic chemotherapy regimens } \\
\text { compared with } 5 / 16(31 \%) \text { in single-dose group }\end{array}$ \\
\hline
\end{tabular}

\section{Sepulveda-Vildosola 2008}

\begin{tabular}{ll}
\hline Methods & RCT \\
\hline Participants & $\begin{array}{l}\text { Participants under } 16 \text { years old with solid tumours undergoing a total of } 100 \text { courses of highly eme- } \\
\text { togenic chemotherapy (number of individual participants not stated, therefore it is unclear whether } \\
\text { some participants had more than } 1 \text { course included in the study) }\end{array}$ \\
\hline
\end{tabular}

Interventions

In 50 courses, participants received ondansetron $8 \mathrm{mg} / \mathrm{m}^{2}$ IV every 8 hours

In 50 courses, participants received palonosetron $0.25 \mathrm{mg}$ IV single dose

$\begin{array}{ll}\text { Outcomes } & \text { Number of emetic events } \\ \text { Severity of nausea (reported by parents/guardians as impact on oral intake) } \\ \text { Side effects (though not reported which were assessed) }\end{array}$

Notes

\section{Risk of bias}

\begin{tabular}{|c|c|c|}
\hline Bias & Authors' judgement & Support for judgement \\
\hline $\begin{array}{l}\text { Random sequence genera- } \\
\text { tion (selection bias) }\end{array}$ & Unclear risk & Not described \\
\hline $\begin{array}{l}\text { Allocation concealment } \\
\text { (selection bias) }\end{array}$ & Unclear risk & Not described \\
\hline $\begin{array}{l}\text { Blinding (performance } \\
\text { bias and detection bias) } \\
\text { Acute nausea }\end{array}$ & Unclear risk & $\begin{array}{l}\text { Double blind. Difference in dose frequency may have meant participants were } \\
\text { not actually blinded }\end{array}$ \\
\hline $\begin{array}{l}\text { Blinding (performance } \\
\text { bias and detection bias) } \\
\text { Acute vomiting }\end{array}$ & Unclear risk & $\begin{array}{l}\text { Double blind. Difference in dose frequency may have meant participants were } \\
\text { not actually blinded }\end{array}$ \\
\hline $\begin{array}{l}\text { Blinding (performance } \\
\text { bias and detection bias) } \\
\text { Other outcomes }\end{array}$ & Unclear risk & $\begin{array}{l}\text { Double blind. Difference in dose frequency may have meant participants were } \\
\text { not actually blinded }\end{array}$ \\
\hline $\begin{array}{l}\text { Incomplete outcome data } \\
\text { (attrition bias) }\end{array}$ & Low risk & All participants accounted for \\
\hline
\end{tabular}


Sepulveda-Vildosola 2008 (Continued)

All outcomes

Selective reporting (re- Low risk $\quad$ All outcomes reported
porting bias)

Other bias Low risk No other risk of bias noted

Shi 2012

\begin{tabular}{ll}
\hline Methods & RCT \\
\hline Participants & 80 children with solid tumours \\
\hline Interventions & 40 children received ondansetron $4 \mathrm{mg} \mathrm{IV}$ \\
& 40 children received ondansetron 4 mg IV plus hewei zhiou recipe (traditional Chinese medicine) oral \\
\hline Outcomes & Self reported vomiting scores (number of vomits and intensity of vomiting) \\
\hline Notes &
\end{tabular}

\section{Risk of bias}

\begin{tabular}{|c|c|c|}
\hline Bias & Authors' judgement & Support for judgement \\
\hline $\begin{array}{l}\text { Random sequence genera- } \\
\text { tion (selection bias) }\end{array}$ & Low risk & Random digit table \\
\hline $\begin{array}{l}\text { Allocation concealment } \\
\text { (selection bias) }\end{array}$ & Unclear risk & No details \\
\hline $\begin{array}{l}\text { Blinding (performance } \\
\text { bias and detection bias) } \\
\text { Acute nausea }\end{array}$ & Unclear risk & No details \\
\hline $\begin{array}{l}\text { Blinding (performance } \\
\text { bias and detection bias) } \\
\text { Acute vomiting }\end{array}$ & Unclear risk & No details \\
\hline $\begin{array}{l}\text { Blinding (performance } \\
\text { bias and detection bias) } \\
\text { Other outcomes }\end{array}$ & Unclear risk & No details \\
\hline $\begin{array}{l}\text { Incomplete outcome data } \\
\text { (attrition bias) } \\
\text { All outcomes }\end{array}$ & Low risk & All participants accounted for in results \\
\hline $\begin{array}{l}\text { Selective reporting (re- } \\
\text { porting bias) }\end{array}$ & Low risk & All outcomes reported \\
\hline Other bias & Low risk & No other risk of bias noted \\
\hline
\end{tabular}


Siddique 2011

\begin{tabular}{ll}
\hline Methods & RCT \\
\hline Participants & 60 children aged 4 to 11 scheduled to receive high-dose methotrexate \\
\hline Interventions & 30 received ondansetron $4 \mathrm{mg}$ \\
& 30 received granisetron $1 \mathrm{mg}$ \\
\hline Outcomes & Modified MANE scale (self reported occurrence of nausea, retching, or vomiting) \\
& Requirement of additional dose of antiemetic \\
& Side effects \\
\hline
\end{tabular}

Notes

\section{Risk of bias}

\begin{tabular}{|c|c|c|}
\hline Bias & Authors' judgement & Support for judgement \\
\hline $\begin{array}{l}\text { Random sequence genera- } \\
\text { tion (selection bias) }\end{array}$ & Low risk & Stratified using random sampling \\
\hline $\begin{array}{l}\text { Allocation concealment } \\
\text { (selection bias) }\end{array}$ & Unclear risk & Not stated \\
\hline $\begin{array}{l}\text { Blinding (performance } \\
\text { bias and detection bias) } \\
\text { Acute nausea }\end{array}$ & Low risk & Double blind \\
\hline $\begin{array}{l}\text { Blinding (performance } \\
\text { bias and detection bias) } \\
\text { Acute vomiting }\end{array}$ & Low risk & Double blind \\
\hline $\begin{array}{l}\text { Blinding (performance } \\
\text { bias and detection bias) } \\
\text { Other outcomes }\end{array}$ & Low risk & Double blind \\
\hline $\begin{array}{l}\text { Incomplete outcome data } \\
\text { (attrition bias) } \\
\text { All outcomes }\end{array}$ & Low risk & All participants accounted for \\
\hline $\begin{array}{l}\text { Selective reporting (re- } \\
\text { porting bias) }\end{array}$ & Low risk & All outcomes reported \\
\hline Other bias & Low risk & No other risk of bias noted \\
\hline
\end{tabular}

Suarez 1994

\begin{tabular}{ll}
\hline Methods & RCT \\
\hline Participants & $\begin{array}{l}\text { Participants with malignant solid tumours receiving low to moderately emetogenic agents only, i.e. sin- } \\
\text { gle agent or combination therapy with actinomycin, vincristine, methotrexate, cytarabine, etoposide, } \\
\text { doxorubicin, daunorubicin, hydroxycarbamide, asparaginase, bleomycin, and/or vinblastine }(n=23) \text { or } \\
\text { highly emetogenic agents, i.e. high doses of ifosfamide or cyclophosphamide }(n=21)\end{array}$
\end{tabular}


Excluded if: severe hepatic, renal, or cardiac insufficiency; uncontrolled infection; hypersensitivity or drug allergy; or other current or previous medical condition that might confound findings or put person at risk. Administration during study of antiemetic agents other than study drug, neuroleptics, drugs known to induce hepatic enzyme synthesis, and azole antifungal agents were prohibited.

Mean age 10 years, 37/44 participants male

$\begin{array}{ll}\text { Interventions } & \text { (Randomised to } 1 \text { of } 6 \text { strata: placebo, or tropisetron }(0.05,0.10,0.20,0.33, \text { or } 0.50 \mathrm{mg} / \mathrm{kg} \text { ) given as sin- } \\ & \text { gle dose by IV infusion (diluted in normal saline to give volume of } 1 \mathrm{ml} / \mathrm{kg} \text { body weight, administered } \\ \text { over } 15 \text { minutes immediately before start of chemotherapy) or, on discharge, orally in small quantity of } \\ \text { orange juice for } 5,6, \text { or } 7 \text { days when receiving } 1 \text { to } 3,4, \text { or } 5 \text { days chemotherapy, respectively }\end{array}$

\begin{tabular}{ll}
\hline Outcomes & Daily record cards used by participant/family to record nausea and vomiting (unclear exactly how) \\
\hline Notes & Tropisetron and matching placebo ampoules were provided by Sandoz Ltd. \\
\hline
\end{tabular}

\section{Risk of bias}

\begin{tabular}{|c|c|c|}
\hline Bias & Authors' judgement & Support for judgement \\
\hline $\begin{array}{l}\text { Random sequence genera- } \\
\text { tion (selection bias) }\end{array}$ & Low risk & States 2:1 unequal randomisation schedule \\
\hline $\begin{array}{l}\text { Allocation concealment } \\
\text { (selection bias) }\end{array}$ & Unclear risk & Not stated \\
\hline \multirow[t]{3}{*}{$\begin{array}{l}\text { Blinding (performance } \\
\text { bias and detection bias) } \\
\text { Acute nausea }\end{array}$} & Low risk & $\begin{array}{l}\text { States double-blind. No further details. } \\
\text { Blinding of care provider: yes }\end{array}$ \\
\hline & & Blinding of participant: yes \\
\hline & & Blinding of outcome assessors: yes \\
\hline \multirow{4}{*}{$\begin{array}{l}\text { Blinding (performance } \\
\text { bias and detection bias) } \\
\text { Acute vomiting }\end{array}$} & Low risk & States double-blind. No further details. \\
\hline & & Blinding of care provider: yes \\
\hline & & Blinding of participant: yes \\
\hline & & Blinding of outcome assessors: yes \\
\hline \multirow{4}{*}{$\begin{array}{l}\text { Blinding (performance } \\
\text { bias and detection bias) } \\
\text { Other outcomes }\end{array}$} & Low risk & States double-blind. No further details. \\
\hline & & Blinding of care provider: yes \\
\hline & & Blinding of participant: yes \\
\hline & & Blinding of outcome assessors: yes \\
\hline $\begin{array}{l}\text { Incomplete outcome data } \\
\text { (attrition bias) } \\
\text { All outcomes }\end{array}$ & Low risk & $\begin{array}{l}\text { Intention-to-treat analysis stated; withdrawals detailed and included in analy- } \\
\text { sis }\end{array}$ \\
\hline $\begin{array}{l}\text { Selective reporting (re- } \\
\text { porting bias) }\end{array}$ & Unclear risk & Grouping of arms apparently post-hoc and driven by the trial data \\
\hline Other bias & Low risk & No other risk of bias noted \\
\hline
\end{tabular}


Swann 1979

$\begin{array}{ll}\text { Methods } & \text { RCT } \\ \text { Cross-over trial but unclear if multiple cross-overs }\end{array}$

\begin{tabular}{ll}
\hline Participants & $\begin{array}{l}\text { Any paediatric patient receiving chemotherapy for a malignancy. Age range } 2 \text { to } 13 \text { years with } 6 / 18 \text { par- } \\
\text { ticipants male }\end{array}$ \\
\hline Interventions & IV metoclopramide $(0.5 \mathrm{mg} / \mathrm{kg})$ \\
& IV domperidone $(1 \mathrm{mg} / \mathrm{kg})$ \\
\hline Outcomes & $\begin{array}{l}\text { Parents or nurses, or both reported nausea and vomiting episodes and duration. Unvalidated assess- } \\
\text { ment, unclear how undertaken }\end{array}$ \\
\hline Notes & Data used as though parallel trial
\end{tabular}

\section{Risk of bias}

\begin{tabular}{lll}
\hline Bias & Authors' judgement & Support for judgement \\
\hline $\begin{array}{l}\text { Random sequence genera- } \\
\text { tion (selection bias) }\end{array}$ & Unclear risk & Described as "randomised crossover design" \\
\hline $\begin{array}{l}\text { Allocation concealment } \\
\text { (selection bias) }\end{array}$ & Unclear risk & Not stated \\
\hline
\end{tabular}

\begin{tabular}{lll}
\hline Blinding (performance & High risk & Not reported \\
bias and detection bias) & &
\end{tabular}

Acute nausea

\begin{tabular}{lll}
\hline Blinding (performance & High risk & Not reported \\
bias and detection bias) &
\end{tabular}

Acute vomiting

\begin{tabular}{|c|c|c|}
\hline $\begin{array}{l}\text { Blinding (performance } \\
\text { bias and detection bias) } \\
\text { Other outcomes }\end{array}$ & Unclear risk & Not stated \\
\hline
\end{tabular}

\begin{tabular}{lll}
\hline $\begin{array}{l}\text { Incomplete outcome data } \\
\text { (attrition bias) } \\
\text { All outcomes }\end{array}$ & Unclear risk & Not stated \\
\hline $\begin{array}{l}\text { Selective reporting (re- } \\
\text { porting bias) }\end{array}$ & Unclear risk & Not enough detail to assess \\
\hline Other bias & Low risk & No other risk of bias noted \\
\hline
\end{tabular}

Tejedor 1999

\begin{tabular}{ll}
\hline Methods & RCT \\
Serial cross-over
\end{tabular}


Tejedor 1999 (Continued)

Participants
Participants with solid tumour receiving their first (and subsequent) courses of highly emetogenic (ifos or cyclo $>1 \mathrm{~g} / \mathrm{m}^{2}$, MTX $>1 \mathrm{~g} / \mathrm{m}^{2}$, dacarbazine $>100 \mathrm{mg} / \mathrm{m}^{2}$, cisplat $>30 \mathrm{mg} / \mathrm{m}^{2}$, dox $>45 \mathrm{mg} / \mathrm{m}^{2}$, actinoD $>0.3 \mathrm{mg} / \mathrm{m}^{2}$, carbo $\left.>150 \mathrm{mg} / \mathrm{m}^{2}\right)$ plus another agent

Overall mean age 11.5 years (range 2 to 17 years), with 16/30 participants male

$\begin{array}{ll}\text { Interventions } & \text { Tropisetron } 0.2 \mathrm{mg} / \mathrm{kg} \text { IV } 30 \text { minutes prior to infusion } \\ \text { Chlorpromazine } 5 \text { to } 15 \mathrm{mg} \text { given over } 2 \text {-hour infusion and } 2 \text { further } 6 \text {-hourly plus dexamethasone } 2 \\ \mathrm{mg} / \mathrm{m}^{2} \text { IV bolus prior to and at } 12 \text { hours }\end{array}$

\begin{tabular}{ll}
\hline Ontcomes & $\begin{array}{l}\text { Unvalidated 'verbal report' of nausea given by parent/child, and a numerical assessment of vomiting } \\
\text { made }\end{array}$
\end{tabular}

Notes $-\quad$

\section{Risk of bias}

\begin{tabular}{|c|c|c|}
\hline Bias & Authors' judgement & Support for judgement \\
\hline $\begin{array}{l}\text { Random sequence genera- } \\
\text { tion (selection bias) }\end{array}$ & Unclear risk & Not stated \\
\hline $\begin{array}{l}\text { Allocation concealment } \\
\text { (selection bias) }\end{array}$ & Unclear risk & Not stated \\
\hline $\begin{array}{l}\text { Blinding (performance } \\
\text { bias and detection bias) } \\
\text { Acute nausea }\end{array}$ & High risk & Not reported \\
\hline $\begin{array}{l}\text { Blinding (performance } \\
\text { bias and detection bias) } \\
\text { Acute vomiting }\end{array}$ & High risk & Not reported \\
\hline $\begin{array}{l}\text { Blinding (performance } \\
\text { bias and detection bias) } \\
\text { Other outcomes }\end{array}$ & Low risk & $\begin{array}{l}\text { States double-blind. No further details. } \\
\text { Blinding of care provider: yes } \\
\text { Blinding of participant: yes } \\
\text { Blinding of outcome assessors: yes }\end{array}$ \\
\hline $\begin{array}{l}\text { Incomplete outcome data } \\
\text { (attrition bias) } \\
\text { All outcomes }\end{array}$ & High risk & Cross-over with only $50 \%$ second-agent completed \\
\hline $\begin{array}{l}\text { Selective reporting (re- } \\
\text { porting bias) }\end{array}$ & Low risk & - \\
\hline Other bias & Low risk & No other risk of bias noted \\
\hline
\end{tabular}

\section{Tsuchida 1999}

\begin{tabular}{ll}
\hline Methods & RCT \\
Cross-over
\end{tabular}


Tsuchida 1999 (Continued)

Participants Participants with solid tumour receiving 2 identical courses of cyclo $>1.2 \mathrm{mg} / \mathrm{m}^{2}$ or cisplatin $>90 \mathrm{mg} /$ $\mathrm{m}^{2}$. Mean age was 5 years ( 0.85 to 13 years) with $23 / 44$ episodes in males

Interventions

Granisetron $20 \mathrm{mcg} / \mathrm{kg}$ IV prior to chemotherapy

Granisetron $40 \mathrm{mcg} / \mathrm{kg}$ IV prior to chemotherapy

\begin{tabular}{ll}
\hline Outcomes & Unclear who undertook assessment of number of vomiting episodes \\
\hline Notes & -
\end{tabular}

\section{Risk of bias}

\begin{tabular}{lll}
\hline Bias & Authors' judgement & Support for judgement \\
\hline $\begin{array}{l}\text { Random sequence genera- } \\
\text { tion (selection bias) }\end{array}$ & Unclear risk & Not stated \\
\hline $\begin{array}{l}\text { Allocation concealment } \\
\text { (selection bias) }\end{array}$ & Unclear risk & Not stated \\
\hline $\begin{array}{l}\text { Blinding (performance } \\
\text { bias and detection bias) } \\
\text { Acute nausea }\end{array}$ & High risk & Not reported \\
\hline $\begin{array}{l}\text { Blinding (performance } \\
\text { bias and detection bias) }\end{array}$ & Unclear risk & Not stated \\
Acute vomiting & & Blinding of care provider: unclear \\
& & Blinding of participant: unclear \\
& & Blinding of outcome assessors: unclear
\end{tabular}

\begin{tabular}{ll}
\hline Blinding (performance & High risk \\
bias and detection bias) & \\
Other outcomes & \\
\hline
\end{tabular}

Incomplete outcome data High risk 3 dropouts in higher-dose ondansetron arm - unclear how accounted for; nil in

(attrition bias) lower-dose arm

All outcomes

Selective reporting (re- Low risk -
porting bias)

\begin{tabular}{ll}
\hline Other bias $\quad$ Low risk $\quad$ Nother risk of bias noted \\
\hline
\end{tabular}

White 2000

\begin{tabular}{ll}
\hline Methods & RCT \\
\hline Participants & $\begin{array}{l}\text { Included people with a variety of malignancies excluding primary and secondary tumours of the CNS, } \\
\text { who were to receive moderately to highly emetogenic chemotherapy agents } \\
\text { interspersed with } 1 \text { or } 2 \text { single days of no or low emetogenic chemotherapy - vincristine, thioguanine). } 8 \text { days (or } \\
16 \% \text { had cisplatin. } \\
\text { Excluded if: primary and secondary tumours of the CNS; BSA }>1.6 \mathrm{~m}^{2}, \text { severe concurrent illness, illness } \\
\text { associated with nausea and vomiting, emesis or severe nausea in } 24 \text { hours preceding chemotherapy, }\end{array}$ \\
\hline
\end{tabular}


White 2000 (Continued)

receiving antiemetics other than those under investigation (or in preceding 24 hours), pregnancy or contraindications to ondansetron or dexamethasone

Mean age 8 years (range 2 to 17 years), $58 \%$ of 250 participants male

*These were: cyclophosphamide, doxorubicin or doxorubicin $\mathrm{HCL}$, etoposide, cytarabine, methotrexate, ifosfamide, cisplatin, actinomycin D. Doses not reported. (Participants receiving low emetogenic agents alone were excluded from the analysis.)

\begin{abstract}
Interventions
215 participants were given a loading dose IVI ondansetron $5 \mathrm{mg} / \mathrm{m}^{2}+$ oral dexamethasone 2 to $4 \mathrm{mg}$ + placebo syrup (20 minutes pre-chemotherapy) then 6 to 8 hours post-loading dose, oral dexamethasone $2 \mathrm{mg} \mathrm{BD}$ if $\mathrm{BSA}<=0.6 \mathrm{~m}^{2}$, or $4 \mathrm{mg} \mathrm{BD}$ if $\mathrm{BSA}>0.6 \mathrm{~m}^{2} .2$ days post-cessation of chemotherapy, oral ondansetron $4 \mathrm{mg}$ syrup BD.

223 participants were given a loading dose ondansetron syrup $8 \mathrm{mg}+$ oral dexamethasone 2 to $4 \mathrm{mg}$ + placebo by IVI ( 20 minutes pre-chemotherapy) then 6 to 8 hours post-loading dose, oral dexamethasone $2 \mathrm{mg} \mathrm{BD}$ if $\mathrm{BSA}<=0.6 \mathrm{~m}^{2}$, or $4 \mathrm{mg} \mathrm{BD}$ if $\mathrm{BSA}>0.6 \mathrm{~m}^{2} .2$ days post-cessation of chemotherapy, oral ondansetron $4 \mathrm{mg}$ syrup BD.
\end{abstract}

\begin{tabular}{ll} 
Outcomes & $\begin{array}{l}\text { Unvalidated nausea and vomiting diary cards completed by parent/guardian, child, or healthcare staff. } \\
\text { Graded nausea as: none, little bit, or very to reflect: none, mild, moderate, severe } \\
\text { Graded appetite as: none, less than usual, same, more than usual. Episodes of vomiting recorded }\end{array}$ \\
\hline Notes & $\begin{array}{l}\text { Placebos identical to the oral and IV ondansetron preparations were provided by Glaxo Wellcome R\&D } \\
\text { Ltd. }\end{array}$
\end{tabular}

\title{
Risk of bias
}

\begin{tabular}{lll}
\hline Bias & Authors' judgement & Support for judgement \\
\hline $\begin{array}{l}\text { Random sequence genera- } \\
\text { tion (selection bias) }\end{array}$ & Low risk & Computer-generated random code \\
\hline $\begin{array}{l}\text { Allocation concealment } \\
\text { (selection bias) }\end{array}$ & Unclear risk & Not stated \\
\hline $\begin{array}{l}\text { Blinding (performance } \\
\text { bias and detection bias) } \\
\text { Acute nausea }\end{array}$ & High risk & Not reported \\
\hline
\end{tabular}

\begin{tabular}{lll}
$\begin{array}{l}\text { Blinding (performance } \\
\text { bias and detection bias) } \\
\text { Acute vomiting }\end{array}$ & High risk & Not reported \\
\hline $\begin{array}{l}\text { Blinding (performance } \\
\text { bias and detection bias) } \\
\text { Other outcomes }\end{array}$ & Low risk & States double-blind. No further details. \\
& Blinding of care provider: yes \\
& Blinding of participant: yes \\
& Blinding of outcome assessors: yes
\end{tabular}

\begin{tabular}{|c|c|c|}
\hline $\begin{array}{l}\text { Incomplete outcome data } \\
\text { (attrition bias) }\end{array}$ & High risk & $\begin{array}{l}\text { Only } 9 / 250 \text { participants were excluded from analysis, and study groups were } \\
\text { very similar in numbers }\end{array}$ \\
\hline
\end{tabular}

Selective reporting (re- Low risk -
porting bias)

Other bias Low risk No other risk of bias noted


Dosing abbreviations:

$\mathrm{BD}=$ twice a day

IV = intravenous

$\mathrm{IVI}=$ intravenous infusion

$\mathrm{OD}=$ once a day

$\mathrm{PO}=$ orally

QDS = four times a day

TDS = three times a day

Chemotherapy abbreviations:

$5 \mathrm{FU}=5$-fluorouracil

$6 \mathrm{MP}=6$-mercaptopurine

$A B V D=$ adriamycin, bleomycin, vincristine, dacarbazine

actinoD = actinomycin $\mathrm{D}$

Ara- $\mathrm{C}=$ cytarabine

carbo $=$ carboplatin

cisplat $=$ cisplatin

cyclo $=$ cyclophosphamide

dox $=$ doxorubicin

dauno = daunorubicin

HD-MTX = high-dose methotrexate

ifos $=$ ifosfamide

pred $=$ prednisolone

vinc $=$ vincristine

\section{Other abbreviations:}

$A L L=$ acute lymphoblastic leukaemia

$\mathrm{AML}=$ acute myeloid leukaemia

$\mathrm{BMT}=$ bone marrow transplant

$B S A=$ body surface area

CNS = central nervous system

MANE $=$ Morrow Assessment of Nausea and Emesis

MRC = Medical Research Council (UK)

$\mathrm{NHL}=$ non-Hodgkin's lymphoma

$\mathrm{PD}=$ progressive disease

$\mathrm{RCT}=$ randomised controlled trial

$\mathrm{Rx}=$ treatment

$\mathrm{SA}=$ surface area

$\mathrm{TBI}=$ total body irradiation

THC = tetrahydrocannabinol

VAS = visual analogue scale

Characteristics of excluded studies [ordered by study ID]

Study Reason for exclusion

Aksoylar $2001 \quad$ 'Day' randomised rather than participant or episode. Results reported per participant

\begin{tabular}{ll}
\hline Alavi 1985 & $<18$-year-olds not extractable \\
\hline Basch 2011 & Not randomised \\
\hline Bauduer 1999 & $<18$-year-olds not extractable \\
\hline Bonaventura 1999 & $<18$-year-olds not extractable \\
\hline Brice 1989 & $<18$-year-olds not extractable \\
\hline Corapcioglu 2005 & Randomisation not adhered to \\
\hline Dana 1987 & $<18$-year-olds not extractable \\
\hline \hline
\end{tabular}

Antiemetic medication for prevention and treatment of chemotherapy-induced nausea and vomiting in childhood (Review) 


\begin{tabular}{|c|c|}
\hline Study & Reason for exclusion \\
\hline Delgado 1983 & $<18$-year-olds not extractable \\
\hline Fauser 1998 & $<18$-year-olds not extractable \\
\hline Feng 2000 & $<18$-year-olds not extractable \\
\hline Feng 2002 & $<18$-year-olds not extractable \\
\hline Forni 2000 & $<18$-year-olds not extractable \\
\hline Friedman 2000 & $<18$-year-olds not extractable \\
\hline Gagen 1984 & $<18$-year-olds not extractable \\
\hline Gez 1989 & $<18$-year-olds not extractable \\
\hline Gorena 1996 & Not randomised \\
\hline Hatae 1989 & Not randomised \\
\hline Herrstedt 2007 & $<18$-year-olds not extractable \\
\hline Hirota 1993a & $\begin{array}{l}\text { Multiple cross-overs, uncertainly about how randomised the data are, no data to extract parallel or } \\
\text { AB/BA results }\end{array}$ \\
\hline Jara 1999 & $<18$-year-olds not extractable \\
\hline Joss 1994 & $<18$-year-olds not extractable \\
\hline Kearsley 1989 & $<18$-year-olds not extractable \\
\hline Keyhanian 2009 & Participants not $<18$ \\
\hline Koseoglu 1998 & $\begin{array}{l}\text { Multiple cross-overs, uncertainly about how randomised the data are, no data to extract parallel or } \\
\text { AB/BA results }\end{array}$ \\
\hline
\end{tabular}

\begin{tabular}{ll}
\hline Luisi 2006 & $\begin{array}{l}\text { Multiple cross-overs, uncertainly about how randomised the data are, no data to extract parallel or } \\
\text { AB/BA results }\end{array}$ \\
\hline Matsuoka 2003 & $<$ 18-year-olds not extractable (only 2 participants, 1 in each arm) \\
\hline Nathan 2006 & n-of-1 randomisation \\
\hline NCT00429702 2007 & Terminated without publication of results \\
\hline Needles 1999 & $<18$-year-olds not extractable \\
\hline Onat 1995 & $<18$-year-olds not extractable \\
\hline Pillai 2011 & $<18$-year-olds not extractable \\
\hline Relling 1993 & $\begin{array}{l}\text { Multiple courses per randomised participant but without any data to enable cluster or first course } \\
\text { assessment }\end{array}$ \\
\hline Roila 1995 & $<18$-year-olds not extractable \\
\hline
\end{tabular}




\begin{tabular}{ll}
\hline Study & Reason for exclusion \\
\hline Roila 1996 & $<18$-year-olds not extractable \\
\hline Roila 1998 & $<18$-year-olds not extractable \\
\hline Roila 2000 & $<18$-year-olds not extractable \\
\hline Stiakaki 1999 & Multiple courses per randomised participant but without any data to enable cluster or first course \\
\hline Sumer 1988 & assessment \\
\hline Tian 2011 & $\begin{array}{l}\text { Multiple courses per randomised participant but without any data to enable cluster or first course } \\
\text { assessment }\end{array}$ \\
\hline Tsukuda 2009 & Participants not $<18$ \\
\hline Yalcin 1999 & Participants not $<18$ \\
\hline Yonemura 2009 & $<18$-year-olds not extractable \\
\hline
\end{tabular}

$A B / B A=$ alternating cross-over trial with each participant receiving either one treatment $(A)$ followed by a second (B), or in the opposite sequence $(B$ then $A)$

Characteristics of studies awaiting assessment [ordered by study ID]

\section{Gómez 1995}

\begin{tabular}{ll}
\hline Methods & $\begin{array}{l}\text { "un estudio comparativo", "fueron asignados en forma aleatoria" (Comparative study, random as- } \\
\text { signment) }\end{array}$ \\
\hline Participants & $\begin{array}{l}\text { "31 pacientes con enfermedad neoplásica recibiendo por primera vez quimioterapia en base a cis- } \\
\text { platino (CDDP) } 100 \mathrm{mg} / \mathrm{m}^{2} \text { " (31 participants receiving chemotherapy for the first time based on cis- } \\
\text { platin) } \\
\text { "la edad media fue de } 43 \text { años (15-69)" (mean } 43 \text { years old, range } 15 \text { to 69) }\end{array}$ \\
\hline Interventions & "tropisetron (TROP) 5 mg IV (grupo 1), TROP 5 mg con dexametasona (DEX) 20 mg IV (grupo 2) 10 \\
\hline mg con DEX $20 \mathrm{mg}$ IV (grupo 3)" & "control total del vómito" y "respuesta completa" (Total control of vomiting and the "complete an- \\
swer")
\end{tabular}

\section{Xu 1997}

\begin{tabular}{ll}
\hline Methods & "a multicenter cooperative study" \\
\hline Participants & 773 participants, no ages given, receiving cisplatin chemotherapy \\
\hline Interventions & "i.v. OND 8 mg once or twice a day" \\
& "i.v. OND 8 mg plus dexamethasone (DXM) 10 mg once a day" \\
\hline
\end{tabular}


Xu 1997 (Continued)

Outcomes Acute and delayed nausea and vomiting

Notes Not available via British Library. No web source

\section{Zeng 1995}

Methods "multiple centre, randomized cross-over trial"

Participants " "patients receiving non-cisplatin chemotherapy (containing CTX and/or ADM)"

155 participants, no ages given

Interventions Ondansetron (Qilu), metoclopramide or Zofran (Glaxo)

\begin{tabular}{ll}
\hline Outcomes & Control of acute vomiting, frequency of vomits \\
\hline Notes & Not available via British Library. No web source \\
\hline
\end{tabular}

Any help in the discovery, translation, and appraisal of these studies would be greatly appreciated.

\section{DATA AND ANALYSES}

Comparison 1. Addition of corticosteroids to 5-HT3 antagonists

\begin{tabular}{lllll}
\hline Outcome or subgroup title & No. of studies & $\begin{array}{l}\text { No. of partici- } \\
\text { pants }\end{array}$ & Statistical method & Effect size \\
\hline 1 Control of immediate vomiting & 2 & 100 & Risk Ratio (Random, 95\% Cl) & $2.03[1.35,3.04]$ \\
\hline
\end{tabular}

Analysis 1.1. Comparison 1 Addition of corticosteroids to 5HT3 antagonists, Outcome 1 Control of immediate vomiting.

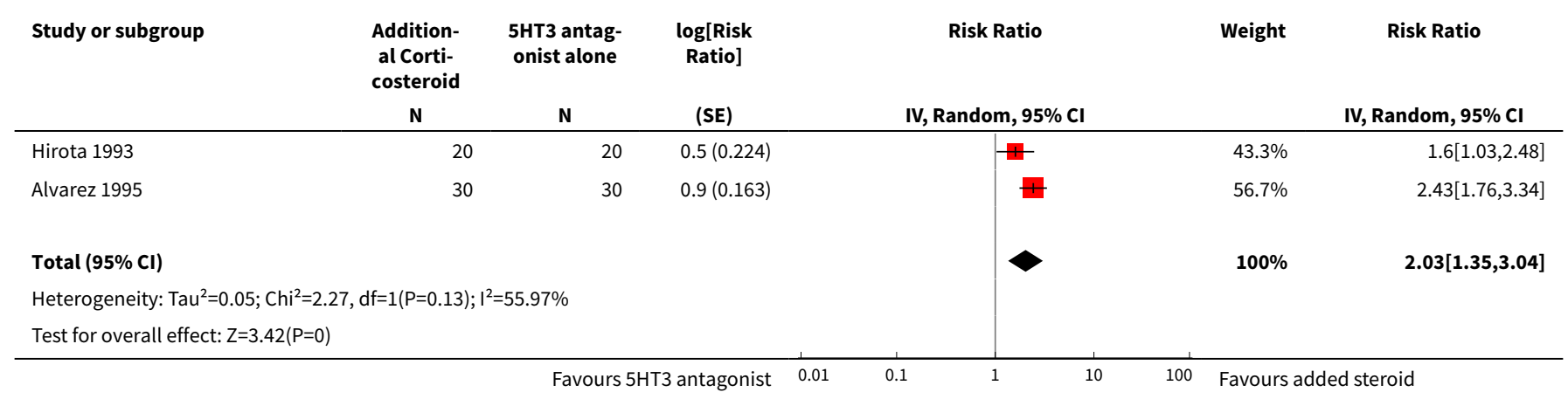


Comparison 2. Granisetron $20 \mathrm{mcg} / \mathrm{kg}$ versus $40 \mathrm{mcg} / \mathrm{kg}$

\begin{tabular}{lllll}
\hline Outcome or subgroup title & No. of studies & $\begin{array}{l}\text { No. of partici- } \\
\text { pants }\end{array}$ & Statistical method & Effect size \\
\hline $\begin{array}{l}1 \text { Complete control of immediate vomit- } \\
\text { ing }\end{array}$ & 3 & 453 & Risk Ratio (Fixed, 95\% Cl) & $0.93[0.80,1.07]$ \\
\hline
\end{tabular}

Analysis 2.1. Comparison 2 Granisetron $20 \mathrm{mcg} / \mathrm{kg}$ versus 40 $\mathrm{mcg} / \mathrm{kg}$, Outcome 1 Complete control of immediate vomiting.

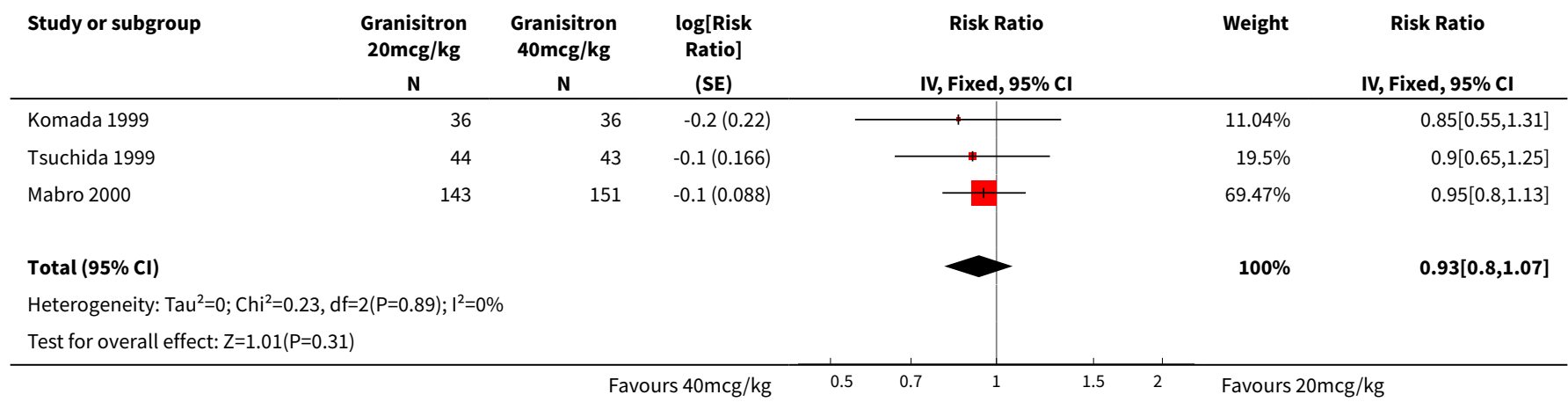

\section{Comparison 3. Ondansetron vs Granisetron}

\begin{tabular}{llllll}
\hline Outcome or subgroup title & No. of studies & $\begin{array}{l}\text { No. of partici- } \\
\text { pants }\end{array}$ & Statistical method & Effect size \\
\hline $\begin{array}{lllll}\text { 1 Complete control of acute nausea } \\
\text { 2 Complete control of acute vomiting }\end{array}$ & 2 & 101 & Risk Ratio (Fixed, 95\% Cl) & $1.05[0.94,1.17]$ \\
\hline $\begin{array}{l}\text { 3 Complete control of delayed nausea } \\
\text { 4 Complete control of delayed vomit- }\end{array}$ & 2 & 167 & 101 & Risk Ratio (Fixed, 95\% Cl) & $2.26[2.04,2.51]$ \\
\hline \begin{tabular}{l} 
ing \\
\hline
\end{tabular} & & 101 & Risk Ratio (Fixed, 95\% Cl) & $1.13[0.93,1.38]$ \\
\hline
\end{tabular}

Analysis 3.1. Comparison 3 Ondansetron vs Granisetron, Outcome 1 Complete control of acute nausea.

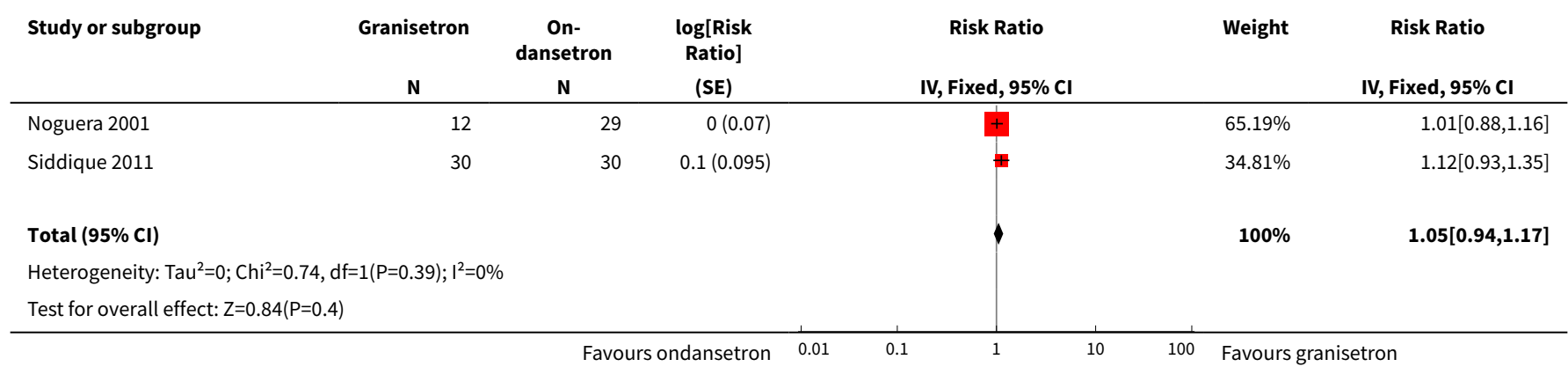


Analysis 3.2. Comparison 3 Ondansetron vs Granisetron, Outcome 2 Complete control of acute vomiting.

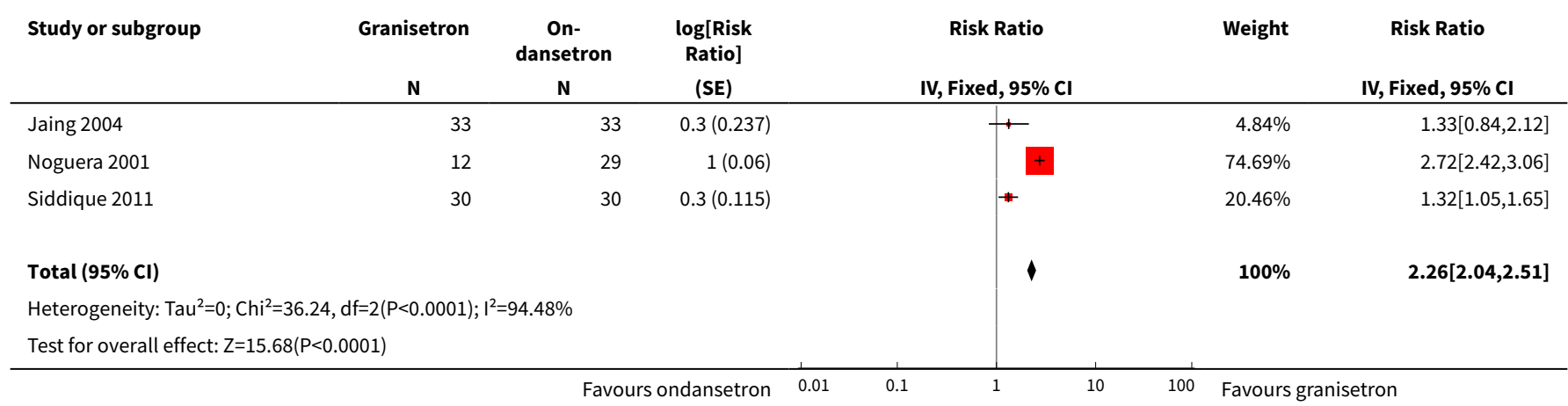

Analysis 3.3. Comparison 3 Ondansetron vs Granisetron, Outcome 3 Complete control of delayed nausea.

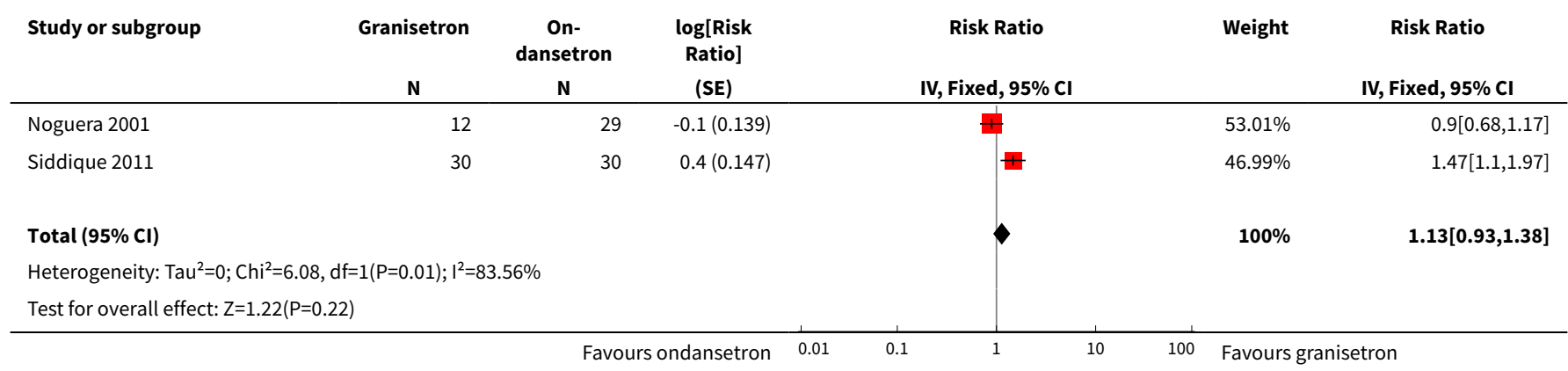

Analysis 3.4. Comparison 3 Ondansetron vs Granisetron, Outcome 4 Complete control of delayed vomiting.

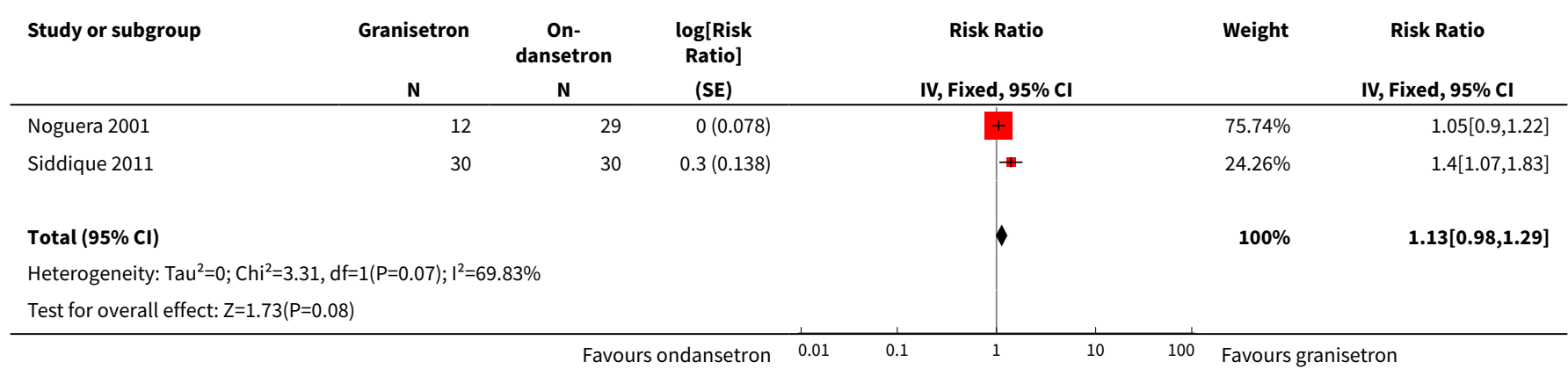

\section{Comparison 4. Other antiemetic comparisons}

\begin{tabular}{|c|c|c|c|c|}
\hline Outcome or subgroup title & No. of studies & $\begin{array}{l}\text { No. of partici- } \\
\text { pants }\end{array}$ & $\begin{array}{l}\text { Statistical } \\
\text { method }\end{array}$ & Effect size \\
\hline 1 Complete control of acute nausea & & & Other data & No numeric data \\
\hline
\end{tabular}




\begin{tabular}{|c|c|c|c|c|}
\hline Outcome or subgroup title & No. of studies & $\begin{array}{l}\text { No. of partici- } \\
\text { pants }\end{array}$ & $\begin{array}{l}\text { Statistical } \\
\text { method }\end{array}$ & Effect size \\
\hline 2 Complete control of acute vomiting & & & Other data & No numeric data \\
\hline 3 Complete control of delayed vomiting & & & Other data & No numeric data \\
\hline $\begin{array}{l}4 \text { Complete control of acute nausea and vom- } \\
\text { iting }\end{array}$ & & & Other data & No numeric data \\
\hline 5 Other nausea \&/or vomiting outcomes & & & Other data & No numeric data \\
\hline
\end{tabular}

Analysis 4.1. Comparison 4 Other antiemetic comparisons, Outcome 1 Complete control of acute nausea.

\begin{tabular}{|c|c|c|c|c|c|c|}
\hline \multicolumn{7}{|c|}{ Complete control of acute nausea } \\
\hline Study & Antiemetic 1 & Antiemetic 2 & $\begin{array}{l}\text { Number receiv- } \\
\text { ing antiemetic } 1\end{array}$ & $\begin{array}{l}\text { Number receiv- } \\
\text { ing antiemetic } 2\end{array}$ & $\begin{array}{l}\text { Relative risk of } \\
\text { complete control } \\
\text { of acute nausea }\end{array}$ & $\begin{array}{c}\text { (95\% confi- } \\
\text { dence interval) }\end{array}$ \\
\hline Brock 1996 & $\begin{array}{l}\text { Ondansetron } 5 \mathrm{mg} / \\
\mathrm{m}^{2} \text { IV over } 15 \mathrm{~min}- \\
\text { utes immediately } \\
\text { prior to chemothera- } \\
\text { py, then at }+8 \text { hours } \\
\text { and }+16 . \text { Ongoing } \\
\text { ondansetron given } \\
\text { orally }<1 \mathrm{~m}^{2} 4 \mathrm{mg} \\
\mathrm{TDS},>1 \mathrm{~m}^{2} 8 \mathrm{mg} \\
\mathrm{TDS}, \text { continued for } \\
3 \text { days after last day } \\
\text { of chemotherapy or } \\
5 \text { days if nausea and } \\
\text { vomiting persisted }\end{array}$ & $\begin{array}{l}\text { Ondansetron } 10 \mathrm{mg} / \\
\mathrm{m}^{2} \mathrm{IV} \text { over } 15 \mathrm{~min}- \\
\text { utes immediately } \\
\text { prior to chemother- } \\
\text { apy, then } 5 \mathrm{mg} / \mathrm{m}^{2} \\
\mathrm{IV} \text { at }+8 \text { hours and } \\
+16 \text {. Ongoing on- } \\
\text { dansetron given } \\
\text { orally }<1 \mathrm{~m}^{2} 4 \mathrm{mg} \\
\mathrm{TDS},>1 \mathrm{~m}^{2} 8 \mathrm{mg} \\
\mathrm{TDS}, \text { continued for } \\
3 \text { days after last day } \\
\text { of chemotherapy or } \\
5 \text { days if nausea and } \\
\text { vomiting persisted }\end{array}$ & 79 patients & 80 patients & 1.01 & 0.81 to 1.25 \\
\hline Ekert 1979 & $\begin{array}{l}\text { Tetrahydrocannabi- } \\
\text { nol (THC) } 10 \mathrm{mg} / \mathrm{m}^{2} \text {, } \\
\text { given at }-2,4,8,16 \\
\text { and } 24 \text { hours around } \\
\text { chemotherapy ad- } \\
\text { ministration }\end{array}$ & $\begin{array}{l}\text { Metoclopramide } 5 \\
\mathrm{mg} \text { (for }<0.7 \mathrm{~m}^{2} \text { pa- } \\
\text { tients) or } 10 \mathrm{mg} \text { (for } \\
>0.7 \mathrm{~m}^{2} \text { patients) } \\
\text { at }-2,8,16 \text { and } 24 \\
\text { hours. Placebo given } \\
\text { at }+4 \text { hours }\end{array}$ & 17 episodes & 25 episodes & 3.53 & 2.28 to 5.46 \\
\hline Ekert 1979a & $\begin{array}{l}\text { Tetrahydrocannabi- } \\
\text { nol (THC) } 10 \mathrm{mg} / \mathrm{m} 2 \text {, } \\
\text { given at }-2,4,8,16 \\
\text { and } 24 \text { hours around } \\
\text { chemotherapy ad- } \\
\text { ministration }\end{array}$ & $\begin{array}{l}\text { Prochlorperazine } \\
\text { - tablets. Weight } \\
\text { based schedule, us- } \\
\text { ing surface area (SA) } \\
0.7 \text { to } 1.1 \mathrm{~m}^{2} 20 \mathrm{mg} / \\
\text { day divided, } \mathrm{SA} 1.1 \\
\text { to } 1.4 \mathrm{~m}^{2} 30 \mathrm{mg} / \mathrm{day} \\
\text { divided, } \mathrm{SA}>1.1 \mathrm{~m}^{2} \\
40 \mathrm{mg} / \text { day divided }\end{array}$ & 18 episodes & 18 episodes & 20.7 & 17.2 to 36.2 \\
\hline Mehta 1986 & $\begin{array}{l}\text { Methylprednisolone } \\
4 \mathrm{mg} / \mathrm{kg} \text { IV } 30 \mathrm{~min}- \\
\text { utes prior to chemo }\end{array}$ & $\begin{array}{l}\text { Chlorpromazine } 0.5 \\
\mathrm{mg} / \mathrm{kg} \text { IV } 30 \text { minutes } \\
\text { prior to chemother- } \\
\text { apy }\end{array}$ & 10 patients & 10 patients & 0.75 & 0.44 to 1.25 \\
\hline Noguera 2001 & $\begin{array}{l}\text { Ondansetron } 0.45 \\
\mathrm{mg} / \mathrm{kg} \text { IV } 15 \text { minutes } \\
\text { after chemotherapy }\end{array}$ & $\begin{array}{l}\text { Tropisetron } 0.20 \mathrm{mg} / \\
\mathrm{kg} \text { IV } 15 \text { minutes af- } \\
\text { ter chemotherapy }\end{array}$ & 29 episodes & 20 episodes & 0.97 & 0.54 to 1.69 \\
\hline Sandoval 1999 & $\begin{array}{l}\text { Ondansetron } 0.6 \\
\mathrm{mg} / \mathrm{kg} \text { (max } 32 \mathrm{mg} \text { ) } \\
\text { IV over } 30 \text { minutes } \\
\text { before chemothera- } \\
\text { py }\end{array}$ & $\begin{array}{l}\text { Ondansetron } 0.15 \\
\mathrm{mg} / \mathrm{kg} \text { (max } 8 \mathrm{mg} \text { ) IV } \\
\text { over } 30 \text { minutes be- } \\
\text { fore chemotherapy } \\
\text { then every } 4 \text { hours } \\
\text { for a total of } 4 \text { doses }\end{array}$ & 16 patients & 15 patients & 1.25 & 0.70 to 2.22 \\
\hline Suarez 1994 & $\begin{array}{l}\text { Placebo, or tro- } \\
\text { pisetron }(0.05 \mathrm{mg} / \\
\mathrm{kg}) \text { given as single } \\
\text { dose }\end{array}$ & $\begin{array}{l}\text { Placebo, or tro- } \\
\text { pisetron ( } 0.1 \text { to } 0.4 \\
\mathrm{mg} / \mathrm{kg} \text { ) given as sin- } \\
\text { gle dose }\end{array}$ & 26 patients & 18 patients & 0.98 & 0.54 to 1.74 \\
\hline
\end{tabular}


Analysis 4.2. Comparison 4 Other antiemetic comparisons, Outcome 2 Complete control of acute vomiting.

\begin{tabular}{|c|c|c|c|c|c|c|}
\hline \multicolumn{7}{|c|}{ Complete control of acute vomiting } \\
\hline Study & Antiemetic 1 & Antiemetic 2 & $\begin{array}{l}\text { Number assessed } \\
\text { antiemetic } 1\end{array}$ & $\begin{array}{l}\text { Number assessed } \\
\text { antiemetic } 2\end{array}$ & $\begin{array}{c}\text { Relative risk of } \\
\text { complete control } \\
\text { of acute vomiting }\end{array}$ & $\begin{array}{l}\text { (95\% confi- } \\
\text { dence interval) }\end{array}$ \\
\hline Alvarez 1995 & $\begin{array}{l}\text { Ondansetron, IV, } \\
0.15 \mathrm{mg} / \mathrm{kg} 30 \\
\text { minutes prior to } \\
\text { chemotherapy, then } \\
\mathrm{BD} \text { on chemother- } \\
\text { apy for } 1 \text { to } 5 \text { days } \\
\text { plus dexamethasone } \\
\text { either } 4 \mathrm{mg} / \mathrm{m}^{2} \mathrm{QDS} \\
\text { or } 8 \mathrm{mg} / \mathrm{m}^{2} \mathrm{BD} \text { (de- } \\
\text { pended on institu- } \\
\text { tion) }\end{array}$ & $\begin{array}{l}\text { Ondansetron, IV, } \\
0.15 \mathrm{mg} / \mathrm{kg} 30 \\
\text { minutes prior to } \\
\text { chemotherapy, then } \\
\mathrm{BD} \text { on chemo for } 1 \text { to } \\
5 \text { days }\end{array}$ & 30 episodes & 30 episodes & 2.43 & 1.76 to 3.34 \\
\hline Basade 1996 & $\begin{array}{l}\text { Dexamethasone } 8 \\
\mathrm{mg} / \mathrm{m}^{2} \mathrm{IV} 15 \text { minutes } \\
\text { prior to chemother- } \\
\text { apy }\end{array}$ & $\begin{array}{l}\text { Metoclopramide } 1.5 \\
\mathrm{mg} / \mathrm{kg} \text { IV } 15 \text { minutes } \\
\text { prior to chemother- } \\
\text { apy }\end{array}$ & 53 episodes & 52 episodes & 2.10 & 1.77 to 2.50 \\
\hline Berrak 2007 & $\begin{array}{l}\text { Granisetron } 10 \mathrm{mcg} / \\
\mathrm{kg} \mathrm{IV} 30 \text { minutes pri- } \\
\text { or to } \mathrm{Rx}\end{array}$ & $\begin{array}{l}\text { Granisetron } 40 \mathrm{mcg} / \\
\mathrm{kg} \text { IV } 30 \text { minutes pri- } \\
\text { or to } \mathrm{Rx}\end{array}$ & 104 episodes & 121 episodes & 0.88 & 0.70 to 1.10 \\
\hline Brock 1996 & $\begin{array}{l}\text { Ondansetron } 5 \mathrm{mg} / \\
\mathrm{m}^{2} \mathrm{IV} \text { over } 15 \text { min- } \\
\text { utes immediately } \\
\text { prior to chemothera- } \\
\text { py, then at }+8 \text { hours } \\
\text { and }+16 \text {. Ongoing } \\
\text { ondansetron given } \\
\text { orally }<1 \mathrm{~m}^{2} 4 \mathrm{mg} \\
\mathrm{TDS},>1 \mathrm{~m}^{2} 8 \mathrm{mg} \\
\mathrm{TDS} \text {, continued for } \\
3 \text { days after last day } \\
\text { of chemotherapy or } \\
5 \text { days if nausea and } \\
\text { vomiting persisted. }\end{array}$ & $\begin{array}{l}\text { Ondansetron } 10 \mathrm{mg} / \\
\mathrm{m}^{2} \mathrm{IV} \text { over } 15 \mathrm{~min}- \\
\text { utes immediately } \\
\text { prior to chemother- } \\
\text { apy, then } 5 \mathrm{mg} / \mathrm{m}^{2} \\
\text { IV at + } 8 \text { hours and } \\
+16 \text {. Ongoing on- } \\
\text { dansetron given } \\
\text { orally }<1 \mathrm{~m}^{2} 4 \mathrm{mg} \\
\mathrm{TDS},>1 \mathrm{~m}^{2} 8 \mathrm{mg} \\
\mathrm{TDS} \text {, continued for } \\
3 \text { days after last day } \\
\text { of chemotherapy or } \\
5 \text { days if nausea and } \\
\text { vomiting persisted. }\end{array}$ & 79 patients & 79 patients & 0.89 & 0.72 to 1.10 \\
\hline Chan 1987 & $\begin{array}{l}\text { Nabilone orally (cap- } \\
\text { sules) starting } 8 \\
\text { to } 12 \text { hours prior } \\
\text { to chemotherapy } \\
\text { and repeated } 2 \text { or } 3 \\
\text { times a day accord- } \\
\text { ing to dosage sched- } \\
\text { ule }\end{array}$ & $\begin{array}{l}\text { Prochlorperazine } \\
\text { orally (capsules) } \\
\text { starting } 8 \text { to } 12 \text { hours } \\
\text { prior to chemother- } \\
\text { apy and repeated } 2 \\
\text { or } 3 \text { times a day ac- } \\
\text { cording to dosage } \\
\text { schedule }\end{array}$ & 30 episodes & 30 episodes & 1.00 & 0.85 to 1.17 \\
\hline Dick 1995 & $\begin{array}{l}\text { Ondansetron } 3 \text { to } 8 \\
\mathrm{mg} / \mathrm{m}^{2} \text { given pre- } \\
\text { chemotherapy, then } \\
\mathrm{BD} \text { initially IV then } \\
\text { orally for } 3 \text { days }\end{array}$ & $\begin{array}{l}\text { Metoclopramide } 10 \\
\mathrm{mg} / \mathrm{m}^{2} \mathrm{IV} \text { QDS for } \\
3 \text { days, with } 2.5 \mathrm{mg} \\
\text { procyclidine. Dex- } \\
\text { amethasone } 4 \mathrm{mg} / \\
\mathrm{m}^{2} \mathrm{IV} \text { then } 2 \mathrm{mg} / \mathrm{m}^{2} \\
\text { TDS IV or PO }\end{array}$ & 15 patients & 15 patients & 3.67 & 2.25 to 5.98 \\
\hline Ekert 1979 & $\begin{array}{l}\text { Tetrahydrocannabi- } \\
\text { nol (THC) } 10 \mathrm{mg} / \mathrm{m}^{2} \text {, } \\
\text { given at }-2,4,8,16 \\
\text { and } 24 \text { hours around } \\
\text { chemotherapy ad- } \\
\text { ministration }\end{array}$ & $\begin{array}{l}\text { Metoclopramide } 5 \\
\mathrm{mg} \text { (for }<0.7 \mathrm{~m}^{2} \mathrm{pa}- \\
\text { tients) or } 10 \mathrm{mg} \text { (for } \\
>0.7 \mathrm{~m}^{2} \text { patients) } \\
\text { at }-2,8,16 \text { and } 24 \\
\text { hours. Placebo given } \\
\text { at }+4 \text { hours }\end{array}$ & 17 episodes & 25 episodes & 3.53 & 2.28 to 5.46 \\
\hline Ekert 1979a & $\begin{array}{l}\text { Tetrahydrocannabi- } \\
\text { nol (THC) } 10 \mathrm{mg} / \mathrm{m}^{2} \text {, } \\
\text { given at }-2,4,8,16 \\
\text { and } 24 \text { hours around } \\
\text { chemotherapy ad- } \\
\text { ministration }\end{array}$ & $\begin{array}{l}\text { Prochlorperazine } \\
\text { - tablets. Weight } \\
\text { based schedule SA } \\
0.7 \text { to } 1.1 \mathrm{~m}^{2} 20 \mathrm{mg} / \\
\text { day divided, SA } 1.1 \\
\text { to } 1.4 \mathrm{~m}^{2} 30 \mathrm{mg} / \text { day } \\
\text { divided, SA }>1.1 \mathrm{~m}^{2} \\
40 \mathrm{mg} / \text { day divided }\end{array}$ & 18 episodes & 18 episodes & 19.00 & 13.71 to 26.33 \\
\hline Hirota 1993 & $\begin{array}{l}\text { Granisetron } 40 \mathrm{mcg} / \\
\mathrm{kg} \text { IV } 30 \text { minutes pri- } \\
\text { or to Rx plus methyl- }\end{array}$ & $\begin{array}{l}\text { Granisetron } 40 \mathrm{mcg} / \\
\mathrm{kg} \text { IV } 30 \text { minutes pri- } \\
\text { or to } \mathrm{Rx}\end{array}$ & 20 episodes & 20 episodes & 1.60 & 1.03 to 2.48 \\
\hline
\end{tabular}




\begin{tabular}{|c|c|c|c|c|c|c|}
\hline \multicolumn{7}{|c|}{ Complete control of acute vomiting } \\
\hline Study & Antiemetic 1 & Antiemetic 2 & $\begin{array}{l}\text { Number assessed } \\
\text { antiemetic } 1\end{array}$ & $\begin{array}{l}\text { Number assessed } \\
\text { antiemetic } 2\end{array}$ & $\begin{array}{l}\text { Relative risk of } \\
\text { complete control } \\
\text { of acute vomiting }\end{array}$ & $\begin{array}{c}\text { (95\% confi- } \\
\text { dence interval) }\end{array}$ \\
\hline & $\begin{array}{l}\text { prednisolone } 10 \mathrm{mg} / \\
\mathrm{kg}(\mathrm{max} 500 \mathrm{mg}) \mathrm{IV}\end{array}$ & & & & & \\
\hline Marshall 1989 & $\begin{array}{l}\text { Cocktail. Meto- } \\
\text { clopramide } 2 \mathrm{mg} / \\
\mathrm{kg} / \mathrm{dose} 0,2,6,12 \\
\text { hours. Dex } 0.7 \mathrm{mg} / \mathrm{kg} \\
0 \text { hours. Benztropine } \\
0.02 \mathrm{mg} / \mathrm{kg} / \text { dose } 0, \\
6 \text { hours. Lorazepam } \\
0.05 \mathrm{mg} / \mathrm{kg} / \text { dose }-1 \\
\text { hour and } 12 \text { hours } \\
\text { (PO - rest IV) }\end{array}$ & $\begin{array}{l}\text { Chlorpromazine } \\
0.825 \mathrm{mg} / \mathrm{kg} \text { QDS IV } \\
\text { for } 4 \text { doses }\end{array}$ & 26 episodes & 26 episodes & 2.40 & 1.76 to 3.27 \\
\hline Mehta 1986 & $\begin{array}{l}\text { Methylprednisolone } \\
4 \mathrm{mg} / \mathrm{kg} \text { IV } 30 \mathrm{~min}- \\
\text { utes prior to chemo }\end{array}$ & $\begin{array}{l}\text { Chlorpromazine } 0.5 \\
\mathrm{mg} / \mathrm{kg} \text { IV } 30 \text { minutes } \\
\text { prior to chemother- } \\
\text { apy }\end{array}$ & 10 patients & 10 patients & 1.00 & 0.54 to 1.86 \\
\hline Parker 2001 & $\begin{array}{l}\text { Placebo (saline) IV } \\
15 \text {-minute infusion } \\
30 \text { minutes prior to } \\
\text { lumbar puncture }\end{array}$ & $\begin{array}{l}\text { Low-dose on- } \\
\text { dansetron } 0.15 \mathrm{mg} / \\
\mathrm{kg} \mathrm{IV} 15 \text {-minute infu- } \\
\text { sion } 30 \text { minutes pri- } \\
\text { or to lumbar punc- } \\
\text { ture }\end{array}$ & 51 episodes & 47 episodes & 0.51 & 0.38 to 0.69 \\
\hline Safonova 1999 & $\begin{array}{l}\text { Ondansetron } 8 \mathrm{mg} \\
\text { PO BD plus } 4 \text { to } 8 \mathrm{mg} \\
\text { dexamethasone IV }\end{array}$ & $\begin{array}{l}\text { Ondansetron } 5 \mathrm{mg} / \\
\mathrm{m}^{2} \mathrm{IV} \text { BD plus } 4 \text { to } 8 \\
\mathrm{mg} \text { dexamethasone } \\
\mathrm{IV}\end{array}$ & 26 patients & 26 patients & 1.04 & 0.62 to 1.75 \\
\hline Sandoval 1999 & $\begin{array}{l}\text { Ondansetron } 0.6 \\
\mathrm{mg} / \mathrm{kg} \text { (max } 32 \mathrm{mg} \text { ) } \\
\text { IV over } 30 \text { minutes } \\
\text { before chemothera- } \\
\text { py. }\end{array}$ & $\begin{array}{l}\text { Ondansetron } 0.15 \\
\mathrm{mg} / \mathrm{kg} \text { (max } 8 \mathrm{mg} \text { ) IV } \\
\text { over } 30 \text { minutes be- } \\
\text { fore chemotherapy } \\
\text { then every } 4 \text { hours } \\
\text { for a total of } 4 \text { doses }\end{array}$ & 16 patients & 15 patients & 0.94 & 0.49 to 1.79 \\
\hline Suarez 1994 & $\begin{array}{l}\text { Placebo, or tro- } \\
\text { pisetron }(0.05 \mathrm{mg} / \\
\mathrm{kg}) \text { given as single } \\
\text { dose }\end{array}$ & $\begin{array}{l}\text { Placebo, or tro- } \\
\text { pisetron ( } 0.1 \text { to } 0.4 \\
\mathrm{mg} / \mathrm{kg} \text { ) given as sin- } \\
\text { gle dose }\end{array}$ & 23 patients & 18 patients & 0.89 & 0.51 to 1.54 \\
\hline
\end{tabular}

\section{Analysis 4.3. Comparison 4 Other antiemetic comparisons, Outcome 3 Complete control of delayed vomiting.}

\begin{tabular}{|c|c|c|c|c|c|c|}
\hline \multicolumn{7}{|c|}{ Complete control of delayed vomiting } \\
\hline Study & Antiemetic 1 & Antiemetic 2 & $\begin{array}{l}\text { Number receiv- } \\
\text { ing antiemetic } 1\end{array}$ & $\begin{array}{l}\text { Number receiv- } \\
\text { ing antiemetic } 2\end{array}$ & $\begin{array}{l}\text { Relative risk of } \\
\text { complete control of } \\
\text { delayed vomiting }\end{array}$ & $\begin{array}{c}\text { (95\% confi- } \\
\text { dence interval) }\end{array}$ \\
\hline
\end{tabular}

Analysis 4.4. Comparison 4 Other antiemetic comparisons, Outcome 4 Complete control of acute nausea and vomiting.

\begin{tabular}{|c|c|c|c|c|c|c|}
\hline \multicolumn{7}{|c|}{ Complete control of acute nausea and vomiting } \\
\hline Study & Antiemetic 1 & Antiemetic 2 & $\begin{array}{l}\text { Number receiv- } \\
\text { ing antiemetic } 1\end{array}$ & $\begin{array}{l}\text { Number receiv- } \\
\text { ing antiemetic } 2\end{array}$ & $\begin{array}{l}\text { Relative risk of } \\
\text { complete con- } \\
\text { trol of acute nau- } \\
\text { sea \& vomiting }\end{array}$ & $\begin{array}{c}\text { (95\% Confi- } \\
\text { dence interval) }\end{array}$ \\
\hline Dick 1995 & $\begin{array}{l}\text { Ondansetron } 3 \text { to } 8 \\
\mathrm{mg} / \mathrm{m}^{2} \text { given pre- } \\
\text { chemotherapy, then } \\
\mathrm{BD} \text { initially IV then } \\
\text { orally for } 3 \text { days }\end{array}$ & $\begin{array}{l}\text { Metoclopramide } 10 \\
\mathrm{mg} / \mathrm{m}^{2} \mathrm{IV} \text { QDS for } \\
3 \text { days, with } 2.5 \mathrm{mg} \\
\text { procyclidine Dexam- } \\
\text { ethasone } 4 \mathrm{mg} / \mathrm{m}^{2} \mathrm{IV} \\
\text { then } 2 \mathrm{mg} / \mathrm{m}^{2} \mathrm{TDS} \text { IV } \\
\text { or PO }\end{array}$ & 15 patients & 15 patients & 3.67 & 2.25 to 5.98 \\
\hline
\end{tabular}




\begin{tabular}{|c|c|c|c|c|c|c|}
\hline \multicolumn{7}{|c|}{ Complete control of acute nausea and vomiting } \\
\hline Study & Antiemetic 1 & Antiemetic 2 & $\begin{array}{l}\text { Number receiv- } \\
\text { ing antiemetic } 1\end{array}$ & $\begin{array}{l}\text { Number receiv- } \\
\text { ing antiemetic } 2\end{array}$ & $\begin{array}{l}\text { Relative risk of } \\
\text { complete con- } \\
\text { trol of acute nau- } \\
\text { sea \& vomiting }\end{array}$ & $\begin{array}{c}\text { (95\% Confi- } \\
\text { dence interval) }\end{array}$ \\
\hline Mabro 2000 & $\begin{array}{l}20 \mu \mathrm{g} / \mathrm{kg} \text { oral } \\
\text { granisetron (orange } \\
\text { flavoured) given } \\
1 \text { hour before and } \\
\text { again } 6 \text { to } 12 \text { hours }\end{array}$ & $\begin{array}{l}40 \mu \mathrm{g} / \mathrm{kg} \text { oral } \\
\text { granisetron (orange } \\
\text { flavoured) given } \\
1 \text { hour before and } \\
\text { again } 6 \text { to } 12 \text { hours }\end{array}$ & 143 patients & 151 patients & 0.96 & 0.82 to 1.14 \\
\hline Sandoval 1999 & $\begin{array}{l}\text { Ondansetron } 0.6 \\
\mathrm{mg} / \mathrm{kg} \text { (max } 32 \mathrm{mg} \text { ) } \\
\text { IV over } 30 \text { minutes } \\
\text { before chemothera- } \\
\text { py. }\end{array}$ & $\begin{array}{l}\text { Ondansetron } 0.15 \\
\mathrm{mg} / \mathrm{kg} \text { (max } 8 \mathrm{mg} \text { ) IV } \\
\text { over } 30 \text { minutes be- } \\
\text { fore chemotherapy } \\
\text { then every } 4 \text { hours } \\
\text { for a total of } 4 \text { doses }\end{array}$ & 16 patients & 15 patients & 1.25 & 0.70 to 2.23 \\
\hline Tejedor 1999 & $\begin{array}{l}\text { Tropisetron } 0.2 \mathrm{mg} / \\
\mathrm{kg} \mathrm{IV} 30 \text { minutes pri- } \\
\text { or to infusion }\end{array}$ & $\begin{array}{l}\text { Chlorpromazine } 5 \text { to } \\
15 \mathrm{mg} \text { given over } 2 \text { - } \\
\text { hour infusion and } 2 \\
\text { further } 6 \text {-hourly plus } \\
\text { dexamethasone } 2 \\
\mathrm{mg} / \mathrm{m}^{2} \mathrm{IV} \text { bolus prior } \\
\text { to and at } 12 \text { hours }\end{array}$ & 44 episodes & 43 episodes & 1.03 & 0.79 to 1.35 \\
\hline
\end{tabular}

Analysis 4.5. Comparison 4 Other antiemetic comparisons, Outcome 5 Other nausea \&/or vomiting outcomes.

\begin{tabular}{|c|c|c|c|c|c|c|c|}
\hline \multicolumn{8}{|c|}{ Other nausea \&/or vomiting outcomes } \\
\hline Study & Antiemetic 1 & Antiemetic 2 & $\begin{array}{l}\text { Number receiv- } \\
\text { ing antiemetic } 1\end{array}$ & $\begin{array}{l}\text { Number receiv- } \\
\text { ing antiemetic } 2\end{array}$ & $\begin{array}{l}\text { Adverse out- } \\
\text { come in pa- } \\
\text { tients/episodes } \\
\text { receiving } \\
\text { antiemetic } 1\end{array}$ & $\begin{array}{l}\text { Adverse out- } \\
\text { come in pa- } \\
\text { tients/episodes } \\
\text { receiving } \\
\text { antiemetic } 2 \\
\end{array}$ & $\begin{array}{l}\text { Outcome de- } \\
\text { tails \& notes }\end{array}$ \\
\hline Dalzell 1986 & $\begin{array}{l}\text { Nabilone } 0.5 \mathrm{mg} \\
\mathrm{BD} \text { if < } 18 \mathrm{~kg}, 1 \\
\mathrm{mg} \text { BD if } 18 \text { to } 36 \\
\mathrm{~kg}, 1 \mathrm{mg} \text { TDS if }> \\
36 \mathrm{~kg}\end{array}$ & $\begin{array}{l}\text { Domperidone } 5 \\
\mathrm{mg} \text { TDS if < } 18 \mathrm{~kg} \text {, } \\
10 \mathrm{mg} \text { TDS if } 18 \text { to } \\
36 \mathrm{~kg}, 15 \mathrm{mg} \text { TDS } \\
\text { if }>36 \mathrm{~kg}\end{array}$ & 18 episodes & 18 episodes & 1.5 & 2.5 & $\begin{array}{l}\text { Mean severity } \\
\text { score }(0=\text { nil, } 3= \\
\text { worst), } P=0.001 \\
\text { by Wilcoxon sign- } \\
\text { rank test }\end{array}$ \\
\hline $\begin{array}{l}\text { Graham-Pole } \\
1986\end{array}$ & $\begin{array}{l}\text { Metoclopramide } \\
0.5 \mathrm{mg} / \mathrm{kg} / \text { dose } \\
\text { IV }\end{array}$ & $\begin{array}{l}\text { Chlorpromazine } \\
0.5 \mathrm{mg} / \mathrm{kg} / \text { dose } \\
\text { IV }\end{array}$ & 24 patients & 26 patients & 3.5 (SD 4.1) & 1.8 (SD 2.3) & $\begin{array}{l}\text { Mean number } \\
\text { of vomits in first } \\
24 \mathrm{hrs}\end{array}$ \\
\hline Hahlen 1995 & $\begin{array}{l}\text { Granisetron } 20 \\
\mathrm{mcg} / \mathrm{kg} \text { IV }\end{array}$ & $\begin{array}{l}\text { Dexamethasone } 2 \\
\mathrm{mg} / \mathrm{m}^{2} \mathrm{~m} 2 \mathrm{IV} \text { plus } \\
\text { Chlorpromazine } \\
0.5 \mathrm{mg} / \mathrm{kg} \mathrm{IVI}\end{array}$ & 46 patients & 42 patients & 1.5 & 7 & $\begin{array}{l}\text { Median number } \\
\text { of vomits in first } \\
24 \mathrm{hrs}, \mathrm{P}=0.001 \\
\text { by Wilcoxon sign- } \\
\text { rank test }\end{array}$ \\
\hline Mehta 1986 & $\begin{array}{l}\text { Methylpred- } \\
\text { nisolone } 4 \text { mg/kg } \\
\text { IV } 30 \text { minutes pri- } \\
\text { or to chemother- } \\
\text { apy }\end{array}$ & $\begin{array}{l}\text { Chlorpromazine } \\
0.5 \mathrm{mg} / \mathrm{kg} \text { IV } 30 \\
\text { minutes prior to } \\
\text { chemotherapy }\end{array}$ & 10 patients & 10 patients & $10.9 \mathrm{~h}$ (SD 3.3h) & $3.2 \mathrm{~h}(\mathrm{SD} 3.1 \mathrm{~h})$ & $\begin{array}{l}\text { Mean duration of } \\
\text { nausea }\end{array}$ \\
\hline Nagel 2008 & $\begin{array}{l}\text { Ondansetron } \\
\text { ( } 0.15 \mathrm{mg} / \mathrm{kg} \text { ) pri- } \\
\text { or to anaethesia } \\
\text { and intrathecal } \\
\text { methotrexate ad- } \\
\text { ministration }\end{array}$ & Placebo & 29 patients & 31 patients & 2 & 0.5 & $\begin{array}{l}\text { Mean number of } \\
\text { vomits (no SD } \\
\text { given, } \mathrm{p}<0.001 \text {, } \\
\text { graph extracted, } \\
\text { in } 24 \mathrm{~h} \text { post proce- } \\
\text { dure) }\end{array}$ \\
\hline Orchard 1999 & $\begin{array}{l}\text { Granisetron: } 10 \\
\mathrm{mcg} / \mathrm{kg} / \mathrm{dose} \\
\text { before start of } \\
\text { chemothera- } \\
\text { py/TBI then every } \\
12 \text { hours }\end{array}$ & $\begin{array}{l}\text { Ondansetron: } \\
\text { loading dose } \\
0.15 \mathrm{mg} / \mathrm{kg} \text { be- } \\
\text { fore start of } \\
\text { chemothera- } \\
\mathrm{py} / \mathrm{TBI} \text { then con- } \\
\text { tinuous infusion } \\
0.03 \mathrm{mg} / \mathrm{kg} / \mathrm{h} \\
\text { rounded to near- } \\
\text { est } 0.1 \mathrm{mg} \text { (until } \\
\text { day of transplant } \\
\text { - day } 0 \text { ) }\end{array}$ & 23 patients & 28 patients & $0.82(0.55$ to 1.09$)$ & $\begin{array}{l}1.14(0.90 \text { to } \\
1.38)\end{array}$ & $\begin{array}{l}\text { Mean nausea } \\
\text { score }(0=\text { nil, } 5= \\
\text { worst })(95 \% \mathrm{Cl})\end{array}$ \\
\hline Orchard 1999 & $\begin{array}{l}\text { Granisetron: } 10 \\
\mathrm{mcg} / \mathrm{kg} / \mathrm{dose} \\
\text { before start of }\end{array}$ & $\begin{array}{l}\text { Ondansetron: } \\
\text { loading dose } \\
0.15 \mathrm{mg} / \mathrm{kg} \text { be- }\end{array}$ & 23 patients & 28 patients & $0.54(0.27$ to 0.81$)$ & 0.87 (0.63 to 1.11$)$ & $\begin{array}{l}\text { Mean number of } \\
\text { vomits in first } 24 \\
\text { hours }(95 \% \mathrm{Cl})\end{array}$ \\
\hline
\end{tabular}

Antiemetic medication for prevention and treatment of chemotherapy-induced nausea and vomiting in childhood (Review) 


\begin{tabular}{|c|c|c|c|c|c|c|c|}
\hline \multicolumn{8}{|c|}{ Other nausea \&/or vomiting outcomes } \\
\hline Study & Antiemetic 1 & Antiemetic 2 & $\begin{array}{l}\text { Number receiv- } \\
\text { ing antiemetic } 1\end{array}$ & $\begin{array}{l}\text { Number receiv- } \\
\text { ing antiemetic } 2\end{array}$ & $\begin{array}{l}\text { Adverse out- } \\
\text { come in pa- } \\
\text { tients/episodes } \\
\text { receiving } \\
\text { antiemetic } 1\end{array}$ & $\begin{array}{l}\text { Adverse out- } \\
\text { come in pa- } \\
\text { tients/episodes } \\
\text { receiving } \\
\text { antiemetic } 2\end{array}$ & $\begin{array}{l}\text { Outcome de- } \\
\text { tails \& notes }\end{array}$ \\
\hline & $\begin{array}{l}\text { chemothera- } \\
\text { py/TBI then every } \\
12 \text { hours }\end{array}$ & $\begin{array}{l}\text { fore start of } \\
\text { chemothera- } \\
\text { py/TBI then con- } \\
\text { tinuous infusion } \\
0.03 \mathrm{mg} / \mathrm{kg} / \mathrm{h} \\
\text { rounded to near- } \\
\text { est } 0.1 \mathrm{mg} \text { (until } \\
\text { day of transplant } \\
\text { - day } 0 \text { ) }\end{array}$ & & & & & \\
\hline
\end{tabular}

ADDITIONAL TABLES

Table 1. Adverse events - 5- $\mathrm{HT}_{3}$ antagonists

\begin{tabular}{|c|c|}
\hline Citation & Adverse events noted \\
\hline Alvarez 1995 & $\begin{array}{l}\text { Not shown separately by intervention. Overall mild-moderate sedation } 49 \% \text {, restlessness } 29 \% \text {, } \\
\text { headache } 17 \% \text {, diarrhoea } 17 \% \text {, and hiccups } 2 \%\end{array}$ \\
\hline Berrak 2007 & None reported in either group (granisetron $10 \mathrm{mcg} / \mathrm{kg}$ or $40 \mathrm{mcg} / \mathrm{kg}$ ) \\
\hline \multirow[t]{2}{*}{ Brock 1996} & $\begin{array}{l}\text { Ondansetron } 5 \mathrm{mg} / \mathrm{m}^{2}: 2 \text { almost certainly related: headache and dizziness. } 2 \text { probably related: } \\
\text { headache and warm feeling }\end{array}$ \\
\hline & Ondansetron $10 \mathrm{mg} / \mathrm{m}^{2}: 1$ probably related: headache \\
\hline Dick 1995 & Ondansetron: leg pains ( 1 ) \\
\hline \multirow[t]{6}{*}{ Hahlen 1995} & Granisetron: \\
\hline & - Somnolence (2) \\
\hline & - Fever (not considered related to primary disease) (8) \\
\hline & - Mild- to moderate-severity headache of short duration (8) \\
\hline & - Abdominal pain (not thought to be related to primary disease) (8) \\
\hline & - Leukopenia (7) \\
\hline
\end{tabular}

Hirota $1993 \quad$ None reported

Jaing $2004 \quad$ Numbers not specified. Adverse effects same in each group: mild headache and constipation

\begin{tabular}{ll}
\hline Komada 1999 & No side effects related to the study medication \\
\hline Mabro 2000 & $20 \mu \mathrm{gg} / \mathrm{kg}$ granisetron: headache $8(6 \%)$, constipation $9(6 \%)$, deranged liver enzymes $8(6 \%)$
\end{tabular}

$40 \mu \mathrm{g} / \mathrm{kg}$ granisetron: headache 14 (9\%), constipation 6 (4\%), deranged liver enzymes 7 (5\%)

Mehta 1997 Ondansetron: headaches (8), mild to moderate sedation (10)

\begin{tabular}{ll}
\hline Noguera 2001 & Numbers not given or specified by antiemetic - "rare" and "low intensity" \\
\hline Orchard 1999 & Not reported separately for children \\
\hline Safonova 1999 & None recorded \\
\hline
\end{tabular}


Table 1. Adverse events - $5-\mathrm{HT}_{3}$ antagonists (Continued)

\begin{tabular}{|c|c|}
\hline Sandoval 1999 & "No patients suffered clinical or laboratory toxicity" \\
\hline Sepulveda-Vildosola 2008 & "None of the patients reported or presented any adverse effect" \\
\hline Siddique 2011 & $\begin{array}{l}\text { "Adverse effects like headache, constipation, abdominal pain and loose motion were com- } \\
\text { mon in both group of children but their number was much less in children who received } \\
\text { granisetron" [compared with ondansetron] }\end{array}$ \\
\hline \multirow[t]{2}{*}{ Suarez 1994} & $\begin{array}{l}\text { Placebo or tropisetron } 0.05 \mathrm{mg} / \mathrm{kg} \text { : anxiety (9), headache (5), abdominal pain (4), sweating (2), and } \\
1 \text { each of hypertension, diarrhoea, fever, and fall }\end{array}$ \\
\hline & $\begin{array}{l}\text { Tropisetron } 0.10 \text { to } 0.50 \mathrm{mg} / \mathrm{kg} \text { : headache (3), tremor (3), rash (3), muscle pain (2), } 1 \text { each of vertigo } \\
\text { and fatigue }\end{array}$ \\
\hline Tejedor 1999 & $\begin{array}{l}\text { Tropisetron: hypertension (1), abdominal pain (5), constipation (2), headache (2), headache and } \\
\text { dizziness (1) }\end{array}$ \\
\hline White 2000 & $\begin{array}{l}\text { Granisetron } 20 \mathrm{mcg} / \mathrm{kg} \text {. Most commonly reported: abdominal/gastrointestinal discomfort and pain } \\
4 \% \text {, fever/pyrexia 3\%, diarrhoea and headaches } 2 \%\end{array}$ \\
\hline & $\begin{array}{l}\text { Granisetron } 40 \mathrm{mcg} / \mathrm{kg} \text {. Most commonly reported: abdominal/gastrointestinal discomfort and pain } \\
3 \% \text {, fever } / \text { pyrexia 3\%, diarrhoea and headaches } 2 \%\end{array}$ \\
\hline
\end{tabular}

Table 2. Adverse events - cannabinoids

\begin{tabular}{ll}
\hline Citation & Adverse events noted \\
\hline Chan 1987 & $\begin{array}{l}\text { Nabilone orally: dizziness (18), drowsiness (24), mood alteration (5), ocular swelling and irritation } \\
\text { (4), orthostatic hypotension (3), muscle twitching (2), increased appetite (1) }\end{array}$ \\
\hline Dalzell 1986 & $\begin{array}{l}\text { Nabilone: hallucinations requiring withdrawal from trial (1), drowsiness (12), dizziness (8), mood } \\
\text { changes (3), pruritis (1), dry mouth (1), vagueness (1), light-headedness (1), increased appetite (1) }\end{array}$ \\
\hline Ekert 1979 & Tetrahydrocannabinol: drowsiness (4) \\
\hline Ekert 1979a & Tetrahydrocannabinol: drowsiness (6), mood alteration (2) \\
\hline
\end{tabular}

Table 3. Adverse events - other agents

\begin{tabular}{ll}
\hline Citation & Adverse events noted \\
\hline Basade 1996 & Dexamethasone: insomnia (1), depression (1), anorexia (1), abdominal pain (1) \\
& Metoclopramide: dystonia (1), depression (3), anorexia (4), abdominal pain (2), headache (1) \\
\hline Chan 1987 & $\begin{array}{l}\text { Prochlorperazine orally: dizziness (1), drowsiness (6), mood alteration (4), ocular swelling and irri- } \\
\text { tation (1), muscle twitching (1) }\end{array}$ \\
\hline Dalzell 1986 & Domperidone: drowsiness (6), dizziness (1), mood changes (1), pruritis (1) \\
\hline Dick 1995 & Metoclopramide and dexamethasone: stomach aches (2), agitation/behaviour (2), tiredness (1) \\
\hline Ekert 1979 & Metoclopramide: drowsiness (2) \\
\hline \hline
\end{tabular}




\section{Table 3. Adverse events - other agents (Continued)}

\begin{tabular}{ll} 
Ekert 1979a & Prochlorperazine: none recorded \\
\hline Emir 2013 & $\begin{array}{l}\text { Cocktail: granisetron, dexamethasone, midazolam, and diphenhydramine: constipation (2), seda- } \\
\text { tion (4), hypotension (2) }\end{array}$
\end{tabular}

Graham-Pole 1986 Metoclopramide: extrapyramidal side effects (5/24), somnolence (2/24)

\begin{tabular}{ll}
\hline Hahlen 1995 & Dexamethasone: \\
& - Somnolence - remained a problem after dose reduction (severe in 7/19) (19) \\
& - Headache (5) \\
- Abdominal pain (5) & - Leukopenia (5) \\
- Extrapyramidal reactions (severe ocular-buccal dyskinesia, moderate choreoathetosis) (2)
\end{tabular}

\section{Kurucu 2012}

\section{Marshall 1989}

Hydroxyzine: side effects in 14 participants in control (ondansetron) and 10 participants in (ondansetron plus) hydroxyzine group, consisting of constipation, headache, and dry mouth

\begin{tabular}{ll} 
Marshall 1989 & $\begin{array}{l}\text { Chlorpromazine: diarrhoea (3) } \\
\text { Cocktail. Metoclopramide, dexamethasone, benzatropine, and lorazepam: diarrhoea (2), dystonia } \\
\text { (1), akasthasia (2) }\end{array}$ \\
\hline Chehta 1986 & Methylprednisolone: sedation (3) \\
\hline Mehta 1997 & Perphenazine plus diphenhydramine: dystonia (2), mild to moderate sedation (24) \\
\hline Swann 1979 & ticipated change in blood count, no deaths, no clinical evidence of jaundice \\
\hline Tejedor 1999 & Chlorpromazine plus dexamethasone: abdominal pain (2), somnolence (2), headaches (7) \\
\hline
\end{tabular}

\section{AP PEN DICES}

\section{Appendix 1. Search strategies for medical databases}

\section{Search used in CENTRAL/The Cochrane Library}

\#1 MeSH descriptor Benzodiazepines explode all trees

\#2 (Alprazolam or Alprazolan or alprox or esparon or apo-alpraz or apoalpraz or cassadan or d-65mt or d65mt or kalma or novo-alprazol or novoalprazol or nu-alpraz or nualpraz or ralozam or u-31,889 or u31,889 or xanax or tafil or trankimazin or Niravam)

\#3 (Anthramycin or antramycin)

\#4 (Bromazepam or anxyrex or apo-bromazepam or bromalich or bromaz or bromazanil or bromazep or lexotan or lexomil or lexotanil or lexatin or ro 5-3350 or ro 53350 or durazanil or gen-bromazepam)

\#5 (Clonazepam or antelepsin or rivotril or ro 5-4023 or ro 54023 or klonopin)

\#6 (Devazepide or $\mathrm{mk}-329$ or $\mathrm{mk329)}$ 
\#7 (Diazepam or apaurin or diazemuls or faustan or relanium or seduxen or sibazon or stesolid or valium or rimapam or tensium or dialar or valclair or diastat or dizac or q-pam or valrelease)

\#8 (Nordazepam or demethyldiazepam or desmethyldiazepam or deoxydemoxepam or nordiazepam or norprazepam or dealkylprazepam or calmday or nordaz or tranxilium $n$ or vegesan)

\#9 (Flumazenil or flumazepil or romazicon or anexate or lanexat or ro 15-1788 or ro 151788 or Anexate)

\#10 (Lorazepam or apo-lorazepam or apolorazepam or ativan or orfidal or temesta or donix or duralozam or durazolam or idalprem or laubeel or lorazep von ct or novo-lorazem or novolorazem or nu-loraz or nuloraz or sedicepan or sinestron or somagerol or tolid or wy-4036 or wy4036 or loraz)

\#11 (Flunitrazepam or fluridrazepam or flunitrazepam-teva or flunizep von ct or ro-5-4200 or ro54200 or flunimerck or flunitrazepamneuraxpharm or flunitrazepam-ratiopharm or fluninoc or rohypnol or narcozep or rohipnol or flunibeta)

\#12 (Flurazepam or dalmane or Dormodor or dalmadorm or staurodorm or apo-flurazepam)

\#13 (Nitrazepam or Nitrodiazepam or alodorm or dormalon or dormo-puren or eatan or imadorm or imeson or mogadon or nitrazadon or nitrazep or novanox or radedorm or remnos or rhoxal-nitrazepam or serenade or somnite)

\section{\#14 (Oxazepam or adumbran or serax or tazepam)}

\#15 (Pirenzepine or pirenzepin or pyrenzepine or ulcoprotect or ulgescum or gastrotsepin or piren-basan or pirenzepin-ratiopharm or gastrozepin)

\section{\#16 (Prazepam or centrax or demetrin or lysanxia or reapam)}

\#17 (Temazepam or 3-hydroxydiazepam or hydroxydiazepam or methyloxazepam or oxydiazepam or pronervon t or remestan or restoril or ro-5-5345 or ro55345 or sah 47-603 or sah 47603 or apo-temazepam or euhypnos or planum or levanxol or pms-temazepam or nutemazepam or novo-temazepam or nortem or normitab or normison or nocturne or temtabs or gen-temazepam or dasuen or signopam or temaze or temazep von ct or tenox or wy-3917 or wy3917 or temaz)

\#18 (Chlordiazepoxide or methaminodiazepoxide or chlozepid or elenium or librium or a-poxide or chlordiazachel or librelease or libritabs or lygen)

\#19 (Chlorazepate or tranxene or tranxilium)

\#20 (Estazolam or nuctalon or prosom or tasedan)

\#21 (Medazepam or nobrium or ro 5-4556 or ro 54556 or rudotel or rusedal)

\#22 (Midazolam or dormicum or ro 21-3981 or ro 213981 or versed or hypnovel)

\#23 (Triazolam or apo-triazo or gen-triazolam or halcyon or halcion or trilam)

\#24 MeSH descriptor Cannabinoids explode all trees

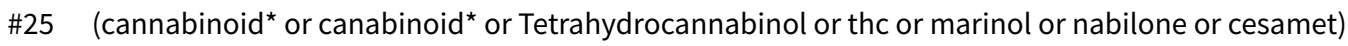

\#26 (\#25 OR \#26)

\#27 MeSH descriptor Beclomethasone, this term only

\#28 (Beclomethasone or beclometasone or qvar or aerobec forte or beclazone or ecobec or filair or aerobec or nasobec aqueous or prolair or respocort or ventolair or vancenase or vanceril or aldecin or viarin or apo-beclomethasone or ascocortonyl or beclamet or beclocort or beclomet or beclorhinol or becloturmant or sanasthmax or beclovent or beconase or propaderm or sanasthmyl or becodisks or becotide or becloforte or bronchocort or junik or asmabec clickhaler or beclazone or clenil modulate)

\#29 MeSH descriptor Betamethasone, this term only

\#30 (Betamethasone or betadexamethasone or flubenisolone or celeston or celestona or celestone or cellestoderm or Betnelan or betnesol)

\#31 MeSH descriptor Betamethasone 17-Valerate, this term only

\#32 (betamethasone 17-valerate or flubenisolonvalerate or betnovate or Beta-val or betaderm or betatrex or dermabet or luxiq or valisone or valnac or betacap or betamethasone valerate or bettamousse or diprosone) 
\#33 MeSH descriptor Budesonide, this term only

\#34 (Budesonide or horacort or pulmicort or rhinocort or novolizer or entocort)

\#35 MeSH descriptor Dexamethasone, this term only

\#36 (Dexamethasone or hexadecadrol or methylfluorprednisolone or dexpak or maxidex or decaject or decameth or decaspray or dexasone or hexadrol or millicorten or oradexon or aeroseb-dex or decaderm dexamethasone or decadron or decadron or mymethasone)

\#37 MeSH descriptor Dexamethasone Isonicotinate, this term only

\#38 (dexamethasone isonicotinate or auxison)

\#39 MeSH descriptor Flumethasone, this term only

\#40 (Flumethasone or fluorodexamethasone or locorten)

\#41 MeSH descriptor Fluorometholone, this term only

\#42 (Fluorometholone or cortisdin or flucon or fluoro-ophtal or fml or pms-fluorometholone or fluoropos or oxylone)

\#43 MeSH descriptor Fluprednisolone, this term only

\#44 (fluprednisolone or alphadrol)

\#45 MeSH descriptor Flurandrenolone, this term only

\#46 (Flurandrenolone or flurandrenolide or cordran or haelan or fludroxycortide)

\#47 MeSH descriptor Melengestrol Acetate, this term only

\#48 (melengestrol acetate or melengestrol)

\#49 MeSH descriptor Methylprednisolone, this term only

\#50 (Methylprednisolone or metipred or medrol or urbason or medrone or solu-medrone or depo-medrone)

\#51 MeSH descriptor Methylprednisolone Hemisuccinate, this term only

\#52 (a-methapred or solu-medrol or solumedrol or urbason-soluble or urbasonsoluble)

\#53 MeSH descriptor Prednisolone, this term only

\#54 (Prednisolone or di-adreson-f or diadresonf or predate or predonine or cortalone or delta-cortef or fernisolone-p or meti-derm or prelone or sterane)

\#55 MeSH descriptor Prednisone, this term only

\#56 (Prednisone or dehydrocortisone or delta-cortisone or prednison galen or prednison hexal or pronisone or rectodelt or apoprednisone or cortancyl or panafcort or dacortin or deltasone or prednidib or predni tablinen or panasol or orasone or meticorten or liquid pred or kortancyl or enkortolon or encortone or encorton or prednison acsis or predniment or decortisyl or cutason or cortan or winpred or ultracorten or sone or sterapred or delta-dome or fernisone or paracort or predincen-m or servisone)

\#57 MeSH descriptor Cyclizine, this term only

\#58 (Cyclizine or marezine or valoid)

\#59 (\#59 OR \#60)

\#60 MeSH descriptor Chlorpromazine, this term only

\#61 (Chlorpromazine or propaphenin or aminazine or chlordelazine or contomin or largactil or fenactil or chlorazine or thorazine or thorazine)

\#62 MeSH descriptor Domperidone, this term only

\#63 (Domperidone or domperidon or apo-domperidone or domidon or domperidon-teva or gastrocure or motilium or nauzelin or novodomperidone or nu-domperidone or pms-domperidone or peridys or ratio-domperidone) 
\#64 MeSH descriptor Droperidol, this term only

\#65 (Droperidol or dehydrobenzperidol or droleptan or dehidrobenzperidol or inapsine or inapsine)

\#66 MeSH descriptor Haloperidol, this term only

\#67 (Haloperidol or haldol or dozic or serenace)

\#68 MeSH descriptor Methotrimeprazine, this term only

\#69 (Methotrimeprazine or levomeprazin or levopromazine or levomepromazine or tisercin or tizertsin or tizercine or levoprome or nozinan)

\#70 MeSH descriptor Metoclopramide, this term only

\#71 (Metoclopramide or metaclopramide or metaclopromide or cerucal or maxolon or primperan or raglan or rimetin)

\#72 MeSH descriptor Perphenazine, this term only

\#73 (Perphenazine or chlorpiprazine or perfenazine or trilafon or fentazin)

\#74 MeSH descriptor Prochlorperazine, this term only

\#75 (Prochlorperazine or compazine or stemetil or buccastem or compro)

\#76 MeSH descriptor Trifluoperazine, this term only

\#77 (Trifluoperazine or trifluoroperazine or trifluperazine or stelazine or triftazin or apo-trifluoperazine or apotrifluoperazine or eskazine or flupazine or terfluzine)

\#78 MeSH descriptor Granisetron, this term only

\#79 MeSH descriptor Ondansetron, this term only

\#80 (granisetron):ti or (granisetron):ab

\#81 (odansetron or ondansetron):ti or (odansetron or ondansetron):ab

\#82 (tropisetron):ti or (tropisetron):ab

\#83 (dolasetron):ti or (dolasetron):ab

\#84 (anzemet):ti or (anzemet):ab

\#85 (kytril or Eutrom or Kevatril or Taraz):ti or (kytril or Eutrom or Kevatril or Taraz):ab

\#86 (zofran or Zofrene or Zophran or Zophren or Avessa or Ceramos):ti or (zofran or Zofrene or Zophran or Zophren or Avessa or Ceramos):ab

\#87 (5- $\mathrm{HT}_{3}$ antagonist $\left.{ }^{\star}\right):$ ti or $\left(5-\mathrm{HT}_{3}\right.$ antagonist $\left.{ }^{\star}\right): \mathrm{ab}$

\#88 (5-HT3 blocker $\left.^{\star}\right):$ ti or $\left(5-\mathrm{HT}_{3}\right.$ blocker $\left.{ }^{\star}\right): \mathrm{ab}$

$\# 89$ \#1 or \#2 or \#3 or \#4 or \#5 or \#6 or \#7 or \#8 or \#9 or \#10 or \#11 or \#12 or \#13 or \#14 or \#15 or \#16 or \#17 or \#18 or \#19 or \#20 or \#21 or \#22 or \#23 or \#24 or \#25 or \#26 or \#27 or \#28 or \#29 or \#30 or \#31 or \#32 or \#33 or \#34 or \#35 or \#36 or \#37 or \#38 or \#39 or \#40 or \#41 or \#42 or \#43 or \#44 or \#45 or \#46 or \#47 or \#48 or \#49 or \#50 or \#51 or \#52 or \#53 or \#54 or \#55 or \#56 or \#57 or \#58 or \#59 or \#60 or \#61 or \#62 or \#63 or \#64 or \#65 or \#66 or \#67 or \#68 or \#69 or \#70 or \#71 or \#72 or \#73 or \#74 or \#75 or \#76 or \#77 or \#78 or \#79 or \#80 or \#81 or \#82 or \#83 or \#84 or \#85 or \#86 or \#87 or \#88

\#90 (infant OR infan* OR newborn OR newborn* OR new-born* OR baby OR baby* OR babies OR neonat* OR child OR child* OR schoolchild* OR schoolchild OR school child OR school child* OR kid OR kids OR toddler* OR adolescent OR adoles* OR teen* OR boy* OR girl* OR minors OR minors* OR underag* OR under ag* OR juvenil* OR youth* OR kindergar* OR puberty OR puber* OR pubescen* OR prepubescen $^{\star}$ OR prepuberty ${ }^{\star}$ OR pediatrics OR pediatric ${ }^{\star}$ OR paediatric ${ }^{\star}$ OR peadiatric ${ }^{\star}$ OR schools OR nursery school* OR preschool ${ }^{\star}$ OR pre school* OR primary school* OR secondary school* OR elementary school* OR elementary school OR high school* OR highschool OR school age OR schoolage OR school age* OR schoolage* OR infancy)

\#91 MeSH descriptor Nausea, this term only 
\#92 (nausea)

\#93 MeSH descriptor Vomiting, this term only

\#94 MeSH descriptor Vomiting, Anticipatory, this term only

\#95 (vomit\$)

\#96 (emesis)

\#97 (sickness)

\#98 (\#91 OR \#92 OR \#93 OR \#94 OR \#95 OR \#96 OR \#97)

\#99 MeSH descriptor Neoplasms explode all trees

\#100 (cancer\$)

\#101 (neoplas\$)

\#102 (oncolog\$)

\#103 (malignan\$)

\#104 (tumor\$ or tumour\$)

\#105 (carcinoma\$)

\#106 (adenocarcinoma\$)

\#107 (sarcoma\$)

\#108 (leukemia or leukaemia)

\#109 (chemotherap\$)

\#110 \#99 or \#100 or \#101 or \#102 or \#103 or \#104 or \#105 or \#106 or \#107 or \#108 or \#109

$\# 111 \# 89$ and \#90 and \#98 and \#110

[\$= zero or many characters; ti=title; $a b=a b s t r a c t]$

All databases were searched

\section{Search used in MEDLINE/OVID and MEDLINE In-process/OVID}

1. exp Benzodiazepines/

2. (Alprazolam or Alprazolan or alprox or esparon or apo-alpraz or apoalpraz or cassadan or d-65mt or d65mt or kalma or novo-alprazol or novoalprazol or nu-alpraz or nualpraz or ralozam or u-31,889 or u31,889 or xanax or tafil or trankimazin or Niravam).ti,ab.

3. (Anthramycin or antramycin).ti,ab.

4. (Bromazepam or anxyrex or apo-bromazepam or bromalich or bromaz or bromazanil or bromazep or lexotan or lexomil or lexotanil or lexatin or ro 5-3350 or ro 53350 or durazanil or gen-bromazepam).ti,ab.

5. (Clonazepam or antelepsin or rivotril or ro 5-4023 or ro 54023 or klonopin).ti,ab.

6. (Devazepide or mk-329 or mk329).ti,ab.

7. (Diazepam or apaurin or diazemuls or faustan or relanium or seduxen or sibazon or stesolid or valium or rimapam or tensium or dialar or valclair or diastat or dizac or q-pam or valrelease).ti,ab.

8. (Nordazepam or demethyldiazepam or desmethyldiazepam or deoxydemoxepam or nordiazepam or norprazepam or dealkylprazepam or calmday or nordaz or tranxilium $n$ or vegesan).ti,ab.

9. (Flumazenil or flumazepil or romazicon or anexate or lanexat or ro 15-1788 or ro 151788 or Anexate).ti,ab. 
10. (Lorazepam or apo-lorazepam or apolorazepam or ativan or orfidal or temesta or donix or duralozam or durazolam or idalprem or laubeel or lorazep von ct or novo-lorazem or novolorazem or nu-loraz or nuloraz or sedicepan or sinestron or somagerol or tolid or wy-4036 or wy4036 or loraz).ti,ab.

11. (Flunitrazepam or fluridrazepam or flunitrazepam-teva or flunizep von ct or ro-5-4200 or ro54200 or flunimerck or flunitrazepamneuraxpharm or flunitrazepam-ratiopharm or fluninoc or rohypnol or narcozep or rohipnol or flunibeta).ti,ab.

12. (Flurazepam or dalmane or Dormodor or dalmadorm or staurodorm or apo-flurazepam).ti,ab.

13. (Nitrazepam or Nitrodiazepam or alodorm or dormalon or dormo-puren or eatan or imadorm or imeson or mogadon or nitrazadon or nitrazep or novanox or radedorm or remnos or rhoxal-nitrazepam or serenade or somnite).ti,ab.

14. (Oxazepam or adumbran or serax or tazepam).ti,ab.

15. (Pirenzepine or pirenzepin or pyrenzepine or ulcoprotect or ulgescum or gastrotsepin or piren-basan or pirenzepin-ratiopharm or gastrozepin).ti,ab.

16. (Prazepam or centrax or demetrin or lysanxia or reapam).ti,ab.

17. (Temazepam or 3-hydroxydiazepam or hydroxydiazepam or methyloxazepam or oxydiazepam or pronervon t or remestan or restoril or ro-5-5345 or ro55345 or sah 47-603 or sah 47603 or apo-temazepam or euhypnos or planum or levanxol or pms-temazepam or nutemazepam or novo-temazepam or nortem or normitab or normison or nocturne or temtabs or gen-temazepam or dasuen or signopam or temaze or temazep von ct or tenox or wy-3917 or wy3917 or temaz).ti,ab.

18. (Chlordiazepoxide or methaminodiazepoxide or chlozepid or elenium or librium or a-poxide or chlordiazachel or librelease or libritabs or lygen).ti,ab.

19. (Chlorazepate or tranxene or tranxilium).ti,ab.

20. (Estazolam or nuctalon or prosom or tasedan).ti,ab.

21. (Medazepam or nobrium or ro 5-4556 or ro 54556 or rudotel or rusedal).ti,ab. (216)

22. (Midazolam or dormicum or ro 21-3981 or ro 213981 or versed or hypnovel).ti,ab.

23. (Triazolam or apo-triazo or gen-triazolam or halcyon or halcion or trilam).ti,ab.

24. or $/ 1-23$

25. exp Cannabinoids/

26. (cannabinoid\$ or canabinoid\$ or Tetrahydrocannabinol or thc or marinol or nabilone or cesamet).ti,ab.

27. 25 or 26

28. Beclomethasone/

29. (Beclomethasone or beclometasone or qvar or aerobec forte or beclazone or ecobec or filair or aerobec or nasobec aqueous or prolair or respocort or ventolair or vancenase or vanceril or aldecin or viarin or apo-beclomethasone or ascocortonyl or beclamet or beclocort or beclomet or beclorhinol or becloturmant or sanasthmax or beclovent or beconase or propaderm or sanasthmyl or becodisks or becotide or becloforte or bronchocort or junik or asmabec clickhaler or beclazone or clenil modulate).ti,ab.

30. Betamethasone/

31. (Betamethasone or betadexamethasone or flubenisolone or celeston or celestona or celestone or cellestoderm or Betnelan or betnesol).ti,ab.

32. betamethasone 17 -valerate/

33. (betamethasone 17-valerate or flubenisolonvalerate or betnovate or Beta-val or betaderm or betatrex or dermabet or luxiq or valisone or valnac or betacap or betamethasone valerate or bettamousse or diprosone).ti,ab.

34. Budesonide/

35. (Budesonide or horacort or pulmicort or rhinocort or novolizer or entocort).ti,ab.

36. Dexamethasone/ 
37. (Dexamethasone or hexadecadrol or methylfluorprednisolone or dexpak or maxidex or decaject or decameth or decaspray or dexasone or hexadrol or millicorten or oradexon or aeroseb-dex or decaderm dexamethasone or decadron or decadron or mymethasone).ti,ab.

38. dexamethasone isonicotinate/

39. (dexamethasone isonicotinate or auxison).ti,ab.

40. flumethasone/

41. (Flumethasone or fluorodexamethasone or locorten).ti,ab.

42. Fluorometholone/

43. (Fluorometholone or cortisdin or flucon or fluoro-ophtal or fml or pms-fluorometholone or fluoropos or oxylone).ti,ab.

44. fluprednisolone/

45. (fluprednisolone or alphadrol).ti,ab.

46. Flurandrenolone/

47. (Flurandrenolone or flurandrenolide or cordran or haelan or fludroxycortide).ti,ab.

48. melengestrol acetate/

49. (melengestrol acetate or melengestrol).ti,ab.

50. Methylprednisolone/

51. (Methylprednisolone or metipred or medrol or urbason or medrone or solu-medrone or depo-medrone).ti,ab.

52. methylprednisolone hemisuccinate/

53. (a-methapred or solu-medrol or solumedrol or urbason-soluble or urbasonsoluble).ti,ab.

54. Prednisolone/

55. (Prednisolone or di-adreson-f or diadresonf or predate or predonine or cortalone or delta-cortef or fernisolone-p or meti-derm or prelone or sterane).ti,ab.

56. Prednisone/

57. (Prednisone or dehydrocortisone or delta-cortisone or prednison galen or prednison hexal or pronisone or rectodelt or apoprednisone or cortancyl or panafcort or dacortin or deltasone or prednidib or predni tablinen or panasol or orasone or meticorten or liquid pred or kortancyl or enkortolon or encortone or encorton or prednison acsis or predniment or decortisyl or cutason or cortan or winpred or ultracorten or sone or sterapred or delta-dome or fernisone or paracort or predincen-m or servisone).ti,ab.

58. or $/ 28-57$

59. Cyclizine/

60. (Cyclizine or marezine or valoid).ti,ab.

61. 59 or 60

62. Chlorpromazine/

63. (Chlorpromazine or propaphenin or aminazine or chlordelazine or contomin or largactil or fenactil or chlorazine or thorazine or thorazine).ti,ab. (10015)

64. Domperidone/

65. (Domperidone or domperidon or apo-domperidone or domidon or domperidon-teva or gastrocure or motilium or nauzelin or novodomperidone or nu-domperidone or pms-domperidone or peridys or ratio-domperidone).ti,ab.

66. Droperidol/ 
67. (Droperidol or dehydrobenzperidol or droleptan or dehidrobenzperidol or inapsine or inapsine).ti,ab.

68. Haloperidol/

69. (Haloperidol or haldol or dozic or serenace).ti,ab.

70. Methotrimeprazine/

71. (Methotrimeprazine or levomeprazin or levopromazine or levomepromazine or tisercin or tizertsin or tizercine or levoprome or nozinan).ti,ab.

72. Metoclopramide/

73. (Metoclopramide or metaclopramide or metaclopromide or cerucal or maxolon or primperan or raglan or rimetin).ti,ab.

74. Perphenazine/

75. (Perphenazine or chlorpiprazine or perfenazine or trilafon or fentazin).ti,ab.

76. Prochlorperazine/

77. (Prochlorperazine or compazine or stemetil or buccastem or compro).ti,ab.

78. Trifluoperazine/

79. (Trifluoperazine or trifluoroperazine or trifluperazine or stelazine or triftazin or apo-trifluoperazine or apotrifluoperazine or eskazine or flupazine or terfluzine).ti,ab.

80. or/62-79

81. granisetron/ or odansetron/

82. granisetron.ti,ab.

83. (odansetron or ondansetron).ti,ab.

84. tropisetron.ti,ab.

85. dolasetron.ti,ab.

86. anzemet.ti,ab.

87. kytril.ti,ab.

88. zofran.ti,ab.

89. 5- $\mathrm{HT}_{3}$ antagonist $\$$.ti,ab.

90. $5-\mathrm{HT}_{3}$ blocker $\$$.ti, ab.

91. or/81-90

92. 24 or 27 or 58 or 61 or 80 or 91

93. adolescent/ or child/ or child, preschool/ or infant/ or infant, newborn/

94. schools/ or schools, nursery/

95. (infant or infan\$ or newborn or newborn\$ or new-born\$ or baby or baby\$ or babies or neonat\$ or child or child\$ or schoolchild \$ or schoolchild or school child or school child\$ or kid or kids or toddler\$ or adolescent or adoles\$ or teen\$ or boy\$ or girl\$ or minors or minors $\$$ or underag $\$$ or under ag $\$$ or juvenil\$ or youth $\$$ or kindergar $\$$ or puberty or puber $\$$ or pubescen $\$$ or prepubescen $\$$ or prepuberty \$ or pediatrics or pediatric $\$$ or paediatric $\$$ or peadiatric $\$$ or schools or nursery school\$ or preschool\$ or pre school\$ or primary school\$ or secondary school\$ or elementary school\$ or elementary school or high school\$ or highschool\$ or school age or schoolage or school age $\$$ or schoolage\$ or infancy or schools, nursery or infant, newborn).ti,ab.

96. 93 or 94 or 95

97. Nausea/

Antiemetic medication for prevention and treatment of chemotherapy-induced nausea and vomiting in childhood (Review) 
98. nausea.ti,ab.

99. vomiting/ or vomiting, anticipatory/

100. vomit\$.ti,ab.

101. emesis.ti,ab.

102. sickness.ti,ab.

103. or/97-102

104. clinical trial.pt.

105. randomized.ab.

106. placebo.ab.

107. randomly.ab.

108. trial.ab.

109. groups.ab.

110. 104 or 105 or 106 or 107 or 108 or 109

111. exp neoplasms/

112. cancer\$.ti,ab.

113. neoplas\$.ti,ab.

114. oncolog $\$ . t i, a b$.

115. malignan $\$ . t i, a b$.

116. tumo?r\$.ti,ab.

117. carcinoma\$.ti,ab.

118. adenocarcinoma\$.ti,ab.

119. sarcoma\$.ti,ab.

120. leuk?mia.ti,ab.

121. chemotherap\$.ti,ab.

122. or/111-121

123. 92 and 96 and 103 and 110 and 122

[\$=zero or many characters; ti,ab=title or abstract; $\mathrm{mp}=$ title, abstract, subject headings, heading word, drug trade name, original title, device manufacturer or drug manufacturer name; /= MeSH term; ab=abstract]

\section{Search used in EMBASE/OVID}

1. Benzodiazepine/ or Alprazolam/ or Anthramycin/ or Bromazepam/ or Clonazepam/ or Devazepide/ or Diazepam/ or Nordazepam/ or Flumazenil/or Lorazepam/ or Flunitrazepam/ or Flurazepam/ or Nitrazepam/ or Oxazepam/ or Pirenzepine/ or Prazepam/ or Temazepam/ or Chlordiazepoxide/ or Clorazepate/ or Estazolam/ or Medazepam/ or Midazolam/ or Triazolam/

2. (Alprazolam or Alprazolan or alprox or esparon or apo-alpraz or apoalpraz or cassadan or d-65mt or d65mt or kalma or novo-alprazol or novoalprazol or nu-alpraz or nualpraz or ralozam or u-31,889 or u31,889 or xanax or tafil or trankimazin or Niravam).ti,ab.

3. (Anthramycin or antramycin).ti,ab.

4. (Bromazepam or anxyrex or apo-bromazepam or bromalich or bromaz or bromazanil or bromazep or lexotan or lexomil or lexotanil or lexatin or ro 5-3350 or ro 53350 or durazanil or gen-bromazepam).ti,ab. 
5. (Clonazepam or antelepsin or rivotril or ro 5-4023 or ro 54023 or klonopin).ti,ab.

6. (Devazepide or mk-329 or mk329).ti,ab.

7. (Diazepam or apaurin or diazemuls or faustan or relanium or seduxen or sibazon or stesolid or valium or rimapam or tensium or dialar or valclair or diastat or dizac or q-pam or valrelease).ti,ab.

8. (Nordazepam or demethyldiazepam or desmethyldiazepam or deoxydemoxepam or nordiazepam or norprazepam or dealkylprazepam or calmday or nordaz or tranxilium $n$ or vegesan).ti,ab.

9. (Flumazenil or flumazepil or romazicon or anexate or lanexat or ro 15-1788 or ro 151788 or Anexate).ti,ab.

10. (Lorazepam or apo-lorazepam or apolorazepam or ativan or orfidal or temesta or donix or duralozam or durazolam or idalprem or laubeel or lorazep von ct or novo-lorazem or novolorazem or nu-loraz or nuloraz or sedicepan or sinestron or somagerol or tolid or wy-4036 or wy4036 or loraz).ti,ab.

11. (Flunitrazepam or fluridrazepam or flunitrazepam-teva or flunizep von ct or ro-5-4200 or ro54200 or flunimerck or flunitrazepamneuraxpharm or flunitrazepam-ratiopharm or fluninoc or rohypnol or narcozep or rohipnol or flunibeta).ti,ab.

12. (Flurazepam or dalmane or Dormodor or dalmadorm or staurodorm or apo-flurazepam).ti,ab.

13. (Nitrazepam or Nitrodiazepam or alodorm or dormalon or dormo-puren or eatan or imadorm or imeson or mogadon or nitrazadon or nitrazep or novanox or radedorm or remnos or rhoxal-nitrazepam or serenade or somnite).ti,ab.

14. (Oxazepam or adumbran or serax or tazepam).ti,ab.

15. (Pirenzepine or pirenzepin or pyrenzepine or ulcoprotect or ulgescum or gastrotsepin or piren-basan or pirenzepin-ratiopharm or gastrozepin).ti,ab.

16. (Prazepam or centrax or demetrin or lysanxia or reapam).ti,ab.

17. (Temazepam or 3-hydroxydiazepam or hydroxydiazepam or methyloxazepam or oxydiazepam or pronervon t or remestan or restoril or ro-5-5345 or ro55345 or sah 47-603 or sah 47603 or apo-temazepam or euhypnos or planum or levanxol or pms-temazepam or nutemazepam or novo-temazepam or nortem or normitab or normison or nocturne or temtabs or gen-temazepam or dasuen or signopam or temaze or temazep von ct or tenox or wy-3917 or wy3917 or temaz).ti,ab.

18. (Chlordiazepoxide or methaminodiazepoxide or chlozepid or elenium or librium or a-poxide or chlordiazachel or librelease or libritabs or lygen).ti,ab.

19. (Chlorazepate or tranxene or tranxilium).ti,ab.

20. (Estazolam or nuctalon or prosom or tasedan).ti,ab.

21. (Medazepam or nobrium or ro 5-4556 or ro 54556 or rudotel or rusedal).ti,ab.

22. (Midazolam or dormicum or ro 21-3981 or ro 213981 or versed or hypnovel).ti,ab.

23. (Triazolam or apo-triazo or gen-triazolam or halcyon or halcion or trilam).ti,ab.

24. or/1-23

25. Cannabinoid/ or Tetrahydrocannabinol/or Cannabinol/ or Cannabidiol/

26. (cannabinoid\$ or canabinoid\$ or Tetrahydrocannabinol or thc or marinol or nabilone or cesamet).ti,ab.

27.25 or 26

28. Beclometasone/

29. (Beclomethasone or beclometasone or qvar or aerobec forte or beclazone or ecobec or filair or aerobec or nasobec aqueous or prolair or respocort or ventolair or vancenase or vanceril or aldecin or viarin or apo-beclomethasone or ascocortonyl or beclamet or beclocort or beclomet or beclorhinol or becloturmant or sanasthmax or beclovent or beconase or propaderm or sanasthmyl or becodisks or becotide or becloforte or bronchocort or junik or asmabec clickhaler or beclazone or clenil modulate).ti,ab.

30. Betamethasone/ 
31. (Betamethasone or betadexamethasone or flubenisolone or celeston or celestona or celestone or cellestoderm or Betnelan or betnesol).ti,ab.

32. Betamethasone Valerate/

33. (betamethasone 17-valerate or flubenisolonvalerate or betnovate or Beta-val or betaderm or betatrex or dermabet or luxiq or valisone or valnac or betacap or betamethasone valerate or bettamousse or diprosone).ti,ab.

\section{Budesonide/}

35. (Budesonide or horacort or pulmicort or rhinocort or novolizer or entocort).ti,ab.

36. Dexamethasone/

37. (Dexamethasone or hexadecadrol or methylfluorprednisolone or dexpak or maxidex or decaject or decameth or decaspray or dexasone or hexadrol or millicorten or oradexon or aeroseb-dex or decaderm dexamethasone or decadron or decadron or mymethasone).ti,ab.

38. Dexamethasone Isonicotinate/

39. (dexamethasone isonicotinate or auxison).ti,ab.

40. Flumetasone/

41. (Flumethasone or fluorodexamethasone or locorten).ti,ab.

42. Fluorometholone/

43. (Fluorometholone or cortisdin or flucon or fluoro-ophtal or fml or pms-fluorometholone or fluoropos or oxylone).ti,ab.

44. fluprednisolone/

45. (fluprednisolone or alphadrol).ti,ab.

46. Fludroxycortide/

47. (Flurandrenolone or flurandrenolide or cordran or haelan or fludroxycortide).ti,ab.

48. melengestrol acetate/

49. (melengestrol acetate or melengestrol).ti,ab.

50. Methylprednisolone/

51. (Methylprednisolone or metipred or medrol or urbason or medrone or solu-medrone or depo-medrone).ti,ab.

52. Methylprednisolone Sodium Succinate/

53. (a-methapred or solu-medrol or solumedrol or urbason-soluble or urbasonsoluble).ti,ab.

54. Prednisolone/

55. (Prednisolone or di-adreson-f or diadresonf or predate or predonine or cortalone or delta-cortef or fernisolone-p or meti-derm or prelone or sterane).ti,ab.

\section{Prednisone/}

57. (Prednisone or dehydrocortisone or delta-cortisone or prednison galen or prednison hexal or pronisone or rectodelt or apo-prednisone or cortancyl or panafcort or dacortin or deltasone or prednidib or predni tablinen or panasol or orasone or meticorten or liquid pred or kortancyl or enkortolon or encortone or encorton or prednison acsis or predniment or decortisyl or cutason or cortan or winpred or ultracorten or sone or sterapred or delta-dome or fernisone or paracort or predincen-m or servisone).ti,ab.

\section{8. or/28-57}

59. Cyclizine/

60. (Cyclizine or marezine or valoid).ti,ab.

61.59 or 60 


\section{Chlorpromazine/}

63. (Chlorpromazine or propaphenin or aminazine or chlordelazine or contomin or largactil or fenactil or chlorazine or thorazine or thorazine).ti,ab.

64. Domperidone/

65. (Domperidone or domperidon or apo-domperidone or domidon or domperidon-teva or gastrocure or motilium or nauzelin or novodomperidone or nu-domperidone or pms-domperidone or peridys or ratio-domperidone).ti,ab.

66. Droperidol/

67. (Droperidol or dehydrobenzperidol or droleptan or dehidrobenzperidol or inapsine or inapsine).ti,ab.

68. Haloperidol/

69. (Haloperidol or haldol or dozic or serenace).ti,ab.

\section{Levomepromazine/}

71. (Methotrimeprazine or levomeprazin or levopromazine or levomepromazine or tisercin or tizertsin or tizercine or levoprome or nozinan).ti,ab.

72. Metoclopramide/

73. (Metoclopramide or metaclopramide or metaclopromide or cerucal or maxolon or primperan or raglan or rimetin).ti,ab.

\section{Perphenazine/}

75. (Perphenazine or chlorpiprazine or perfenazine or trilafon or fentazin).ti,ab.

76. Prochlorperazine/

77. (Prochlorperazine or compazine or stemetil or buccastem or compro).ti,ab.

78. Trifluoperazine/

79. (Trifluoperazine or trifluoroperazine or trifluperazine or stelazine or triftazin or apo-trifluoperazine or apotrifluoperazine or eskazine or flupazine or terfluzine).ti,ab.

80. or/62-79

81. granisetron/ or ondansetron/

82. granisetron.ti,ab.

83. (odansetron or ondansetron).ti,ab.

84. tropisetron.ti,ab.

85. dolasetron.ti,ab.

86. anzemet.ti,ab.

87. (kytril or Eutrom or Kevatril or Taraz).ti,ab.

88. (zofran or Zofrene or Zophran or Zophren or Avessa or Ceramos).ti,ab.

89. 5- $\mathrm{HT}_{3}$ antagonist $\$$.ti,ab.

90. $5-\mathrm{HT}_{3}$ blocker\$.ti,ab.

91. or/81-90

92. 24 or 27 or 58 or 61 or 80 or 91

93. NAUSEA/ or "ANTICIPATORY NAUSEA AND VOMITING"/ or "NAUSEA AND VOMITING"/ 
94. nausea.ti,ab.

95. Vomiting/ or Chemotherapy Induced Emesis/

96. vomit\$.ti,ab.

97. emesis.ti,ab.

98. sickness.ti,ab.

99. or/93-98

100. randomized.ab.

101. placebo.ab.

102. randomly.ab.

103. trial.ab.

104. groups.ab.

105. or/100-104

106. exp neoplasms/

107. cancer\$.ti,ab.

108. neoplas\$.ti,ab.

109. oncolog\$.ti,ab.

110. malignan\$.ti,ab.

111. tumo?r\$.ti,ab.

112. carcinoma\$.ti,ab.

113. adenocarcinoma\$.ti,ab.

114. sarcoma\$.ti,ab.

115. leuk?emia.ti,ab.

116. chemotherap\$.ti,ab.

117. or/106-116

118. infant/ or infancy/ or newborn/ or baby/ or child/ or preschool child/ or school child/

119. adolescent/ or juvenile/ or boy/ or girl/ or puberty/ or prepuberty/ or pediatrics/

120. primary school/ or high school/ or kindergarten/ or nursery school/ or school/

121. (infant\$ or newborn\$ or new born\$ or baby or baby or babies or neonate\$).mp.

122. (child\$ or school child\$ or schoolchild\$ or school age\$ or schoolage\$ or pre school\$ or preschool\$).mp.

123. (kid or kids or toddler\$ or adoles\$ or teen\$ or boy\$ or girl\$).mp.

124. (minors\$ or under ag\$ or underage $\$$ or juvenil\$ or youth\$).mp.

125. (puber\$ or pubescen $\$$ or prepubescen $\$$ or prepubert\$).mp.

126. (pediatric\$ or paediatric\$ or peadiatric\$).mp.

127. (school or schools or high school\$ or highschool\$ or primary school\$ or nursery school\$ or elementary school or secondary school \$or kindergar\$).mp. 


\section{8. or/118-127}

\section{92 and 99 and 105 and 117 and 128}

[\$=zero or many characters; ti,ab=title or abstract; $\mathrm{mp}=$ title, abstract, subject headings, heading word, drug trade name, original title, device manufacturer or drug manufacturer name; /= Emtree term; ab=abstract]

\section{Search used in LILACS/http://bases.bireme.br/cgi-bin/wxislind.exe/iah/online/}

(Benzodiazepine\$ or Alprazolam or Alprazolan or alprox or esparon or apo-alpraz or apoalpraz or cassadan or kalma or novo-alprazol or novoalprazol or nu-alpraz or nualpraz or ralozam or xanax or tafil or trankimazin or Niravam or Anthramycin or antramycin or Bromazepam or anxyrex or apo-bromazepam or bromalich or bromaz or bromazanil or bromazep or lexotan or lexomil or lexotanil or lexatin or durazanil or gen-bromazepam or Clonazepam or antelepsin or rivotril or klonopin or Devazepide or Diazepam or apaurin or diazemuls or faustan or relanium or seduxen or sibazon or stesolid or valium or rimapam or tensium or dialar or valclair or diastat or dizac or q-pam or valrelease or Nordazepam or demethyldiazepam or desmethyldiazepam or deoxydemoxepam or nordiazepam or norprazepam or dealkylprazepam or calmday or nordaz or tranxilium n or vegesan or Flumazenil or flumazepil or romazicon or anexate or lanexat or Anexate or Lorazepam or apo-lorazepam or apolorazepam or ativan or orfidal or temesta or donix or duralozam or durazolam or idalprem or laubeel or lorazep von ct or novo-lorazem or novolorazem or nu-loraz or nuloraz or sedicepan or sinestron or somagerol or tolid or loraz or Flunitrazepam or fluridrazepam or flunitrazepam-teva or flunizep or flunimerck or flunitrazepam-neuraxpharm or flunitrazepam-ratiopharm or fluninoc or rohypnol or narcozep or rohipnol or flunibeta or Flurazepam or dalmane or Dormodor or dalmadorm or staurodorm or apo-flurazepam or Nitrazepam or Nitrodiazepam or alodorm or dormalon or dormo-puren or eatan or imadorm or imeson or mogadon or nitrazadon or nitrazep or novanox or radedorm or remnos or rhoxal-nitrazepam or serenade or somnite or Oxazepam or adumbran or serax or tazepam or Pirenzepine or pirenzepin or pyrenzepine or ulcoprotect or ulgescum or gastrotsepin or piren-basan or pirenzepin-ratiopharm or gastrozepin or Prazepam or centrax or demetrin or lysanxia or reapam or Temazepam or hydroxydiazepam or methyloxazepam or oxydiazepam or pronervon $\mathrm{t}$ or remestan or restoril or apo-temazepam or euhypnos or planum or levanxol or pms-temazepam or nutemazepam or novo-temazepam or nortem or normitab or normison or nocturne or temtabs or gen-temazepam or dasuen or signopam or temaze or temazep von ct or tenox or temaz or Chlordiazepoxide or methaminodiazepoxide or chlozepid or elenium or librium or a-poxide or chlordiazachel or librelease or libritabs or lygen or Chlorazepate or tranxene or tranxilium or Estazolam or nuctalon or prosom or tasedan or Medazepam or nobrium or rudotel or rusedal or Midazolam or dormicum or versed or hypnovel or Triazolam or apo-triazo or gentriazolam or halcyon or halcion or trilam or cannabinoid\$ or canabinoid\$ or Tetrahydrocannabinol or thc or marinol or nabilone or cesamet or Beclomethasone or beclometasone or qvar or aerobec forte or beclazone or ecobec or filair or aerobec or nasobec aqueous or prolair or respocort or ventolair or vancenase or vanceril or aldecin or viarin or apo-beclomethasone or ascocortonyl or beclamet or beclocort or beclomet or beclorhinol or becloturmant or sanasthmax or beclovent or beconase or propaderm or sanasthmyl or becodisks or becotide or becloforte or bronchocort or junik or asmabec clickhaler or beclazone or clenil modulate or Betamethasone or betadexamethasone or flubenisolone or celeston or celestona or celestone or cellestoderm or Betnelan or betnesol or flubenisolonvalerate or betnovate or Beta-val or betaderm or betatrex or dermabet or luxiq or valisone or valnac or betacap or betamethasone valerate or bettamousse or diprosone or Budesonide or horacort or pulmicort or rhinocort or novolizer or entocort or Dexamethasone or hexadecadrol or methylfluorprednisolone or dexpak or maxidex or decaject or decameth or decaspray or dexasone or hexadrol or millicorten or oradexon or aeroseb-dex or decaderm dexamethasone or decadron or decadron or mymethasone or auxison or Flumethasone or fluorodexamethasone or locorten or Fluorometholone or cortisdin or flucon or fluoro-ophtal or fml or pms-fluorometholone or fluoropos or oxylone or fluprednisolone or alphadrol or Flurandrenolone or flurandrenolide or cordran or haelan or fludroxycortide or melengestrol acetate or melengestrol or Methylprednisolone or metipred or medrol or urbason or medrone or solu-medrone or depo-medrone or a-methapred or solu-medrol or solumedrol or urbason-soluble or urbasonsoluble or Prednisolone or di-adreson-f or diadresonf or predate or predonine or cortalone or delta-cortef or fernisolone-p or meti-derm or prelone or sterane or Prednisone or dehydrocortisone or delta-cortisone or prednison galen or prednison hexal or pronisone or rectodelt or apo-prednisone or cortancyl or panafcort or dacortin or deltasone or prednidib or predni tablinen or panasol or orasone or meticorten or liquid pred or kortancyl or enkortolon or encortone or encorton or prednison acsis or predniment or decortisyl or cutason or cortan or winpred or ultracorten or sone or sterapred or delta-dome or fernisone or paracort or predincen-m or servisone or Cyclizine or marezine or valoid or Chlorpromazine or propaphenin or aminazine or chlordelazine or contomin or largactil or fenactil or chlorazine or thorazine or thorazine or Domperidone or domperidon or apo-domperidone or domidon or domperidon-teva or gastrocure or motilium or nauzelin or novo-domperidone or nu-domperidone or pms-domperidone or peridys or ratio-domperidone or Droperidol or dehydrobenzperidol or droleptan or dehidrobenzperidol or inapsine or inapsine or Haloperidol or haldol or dozic or serenace or Methotrimeprazine or levomeprazin or levopromazine or levomepromazine or tisercin or tizertsin or tizercine or levoprome or nozinan or Metoclopramide or metaclopramide or metaclopromide or cerucal or maxolon or primperan or raglan or rimetin or Perphenazine or chlorpiprazine or perfenazine or trilafon or fentazin or Prochlorperazine or compazine or stemetil or buccastem or compro or Trifluoperazine or trifluoroperazine or trifluperazine or stelazine or triftazin or apo-trifluoperazine or apotrifluoperazine or eskazine or flupazine or terfluzine or granisetron or odansetron or ondansetron or tropisetron or dolasetron or anzemet or kytril or Eutrom or Kevatril or Taraz or zofran or Zofrene or Zophran or Zophren or Avessa or Ceramos)

and

(cancer\$ OR neoplas\$ OR oncolog\$ OR malignan\$ OR tumor\$ OR tumour\$ OR carcinoma\$ OR adenocarcinoma\$ OR carcoma\$ OR leukaemia OR leukemia OR chemotherap\$) 
and

(nausea OR vomit\$ OR emesis OR sickness)

[\$=zero or many characters]

\section{Search used in PsycINFO/OVID}

1. benzodiazepines/or alprazolam/or chlordiazepoxide/ or clonazepam/or diazepam/or flunitrazepam/ or flurazepam/or lorazepam/ or midazolam/ or nitrazepam/ or oxazepam/ or triazolam/

2. (Alprazolam or Alprazolan or alprox or esparon or apo-alpraz or apoalpraz or cassadan or d-65mt or d65mt or kalma or novo-alprazol or novoalprazol or nu-alpraz or nualpraz or ralozam or u-31,889 or u31,889 or xanax or tafil or trankimazin or Niravam).ti,ab.

3. (Anthramycin or antramycin).ti,ab.

4. (Bromazepam or anxyrex or apo-bromazepam or bromalich or bromaz or bromazanil or bromazep or lexotan or lexomil or lexotanil or lexatin or ro 5-3350 or ro 53350 or durazanil or gen-bromazepam).ti,ab.

5. (Clonazepam or antelepsin or rivotril or ro 5-4023 or ro 54023 or klonopin).ti,ab.

6. (Devazepide or mk-329 or mk329).ti,ab.

7. (Diazepam or apaurin or diazemuls or faustan or relanium or seduxen or sibazon or stesolid or valium or rimapam or tensium or dialar or valclair or diastat or dizac or q-pam or valrelease).ti,ab.

8. (Nordazepam or demethyldiazepam or desmethyldiazepam or deoxydemoxepam or nordiazepam or norprazepam or dealkylprazepam or calmday or nordaz or tranxilium $\mathrm{n}$ or vegesan).ti,ab.

9. (Flumazenil or flumazepil or romazicon or anexate or lanexat or ro 15-1788 or ro 151788 or Anexate).ti,ab.

10. (Lorazepam or apo-lorazepam or apolorazepam or ativan or orfidal or temesta or donix or duralozam or durazolam or idalprem or laubeel or lorazep von ct or novo-lorazem or novolorazem or nu-loraz or nuloraz or sedicepan or sinestron or somagerol or tolid or wy-4036 or wy4036 or loraz).ti,ab.

11. (Flunitrazepam or fluridrazepam or flunitrazepam-teva or flunizep von ct or ro-5-4200 or ro54200 or flunimerck or flunitrazepamneuraxpharm or flunitrazepam-ratiopharm or fluninoc or rohypnol or narcozep or rohipnol or flunibeta).ti,ab.

12. (Flurazepam or dalmane or Dormodor or dalmadorm or staurodorm or apo-flurazepam).ti,ab.

13. (Nitrazepam or Nitrodiazepam or alodorm or dormalon or dormo-puren or eatan or imadorm or imeson or mogadon or nitrazadon or nitrazep or novanox or radedorm or remnos or rhoxal-nitrazepam or serenade or somnite).ti,ab.

14. (Oxazepam or adumbran or serax or tazepam).ti,ab.

15. (Pirenzepine or pirenzepin or pyrenzepine or ulcoprotect or ulgescum or gastrotsepin or piren-basan or pirenzepin-ratiopharm or gastrozepin).ti,ab.

16. (Prazepam or centrax or demetrin or lysanxia or reapam).ti,ab.

17. (Temazepam or 3-hydroxydiazepam or hydroxydiazepam or methyloxazepam or oxydiazepam or pronervon t or remestan or restoril or ro-5-5345 or ro55345 or sah 47-603 or sah 47603 or apo-temazepam or euhypnos or planum or levanxol or pms-temazepam or nutemazepam or novo-temazepam or nortem or normitab or normison or nocturne or temtabs or gen-temazepam or dasuen or signopam or temaze or temazep von ct or tenox or wy-3917 or wy3917 or temaz).ti,ab.

18. (Chlordiazepoxide or methaminodiazepoxide or chlozepid or elenium or librium or a-poxide or chlordiazachel or librelease or libritabs or lygen).ti,ab.

19. (Chlorazepate or tranxene or tranxilium).ti,ab.

20. (Estazolam or nuctalon or prosom or tasedan).ti,ab.

21. (Medazepam or nobrium or ro 5-4556 or ro 54556 or rudotel or rusedal).ti,ab.

22. (Midazolam or dormicum or ro 21-3981 or ro 213981 or versed or hypnovel).ti,ab.

23. (Triazolam or apo-triazo or gen-triazolam or halcyon or halcion or trilam).ti,ab. 
24. or/1-23

25. cannabinoids/or tetrahydrocannabinol/

26. (cannabinoid\$ or canabinoid\$ or Tetrahydrocannabinol or thc or marinol or nabilone or cesamet).ti,ab.

27. 25 or 26

28. (Beclomethasone or beclometasone or qvar or aerobec forte or beclazone or ecobec or filair or aerobec or nasobec aqueous or prolair or respocort or ventolair or vancenase or vanceril or aldecin or viarin or apo-beclomethasone or ascocortonyl or beclamet or beclocort or beclomet or beclorhinol or becloturmant or sanasthmax or beclovent or beconase or propaderm or sanasthmyl or becodisks or becotide or becloforte or bronchocort or junik or asmabec clickhaler or beclazone or clenil modulate).ti,ab.

29. (Betamethasone or betadexamethasone or flubenisolone or celeston or celestona or celestone or cellestoderm or Betnelan or betnesol).ti,ab.

30. (betamethasone 17-valerate or flubenisolonvalerate or betnovate or Beta-val or betaderm or betatrex or dermabet or luxiq or valisone or valnac or betacap or betamethasone valerate or bettamousse or diprosone).ti,ab.

31. (Budesonide or horacort or pulmicort or rhinocort or novolizer or entocort).ti,ab.

32. Dexamethasone/

33. (Dexamethasone or hexadecadrol or methylfluorprednisolone or dexpak or maxidex or decaject or decameth or decaspray or dexasone or hexadrol or millicorten or oradexon or aeroseb-dex or decaderm dexamethasone or decadron or decadron or mymethasone).ti,ab.

34. (dexamethasone isonicotinate or auxison).ti,ab.

35. (Flumethasone or fluorodexamethasone or locorten).ti,ab.

36. (Fluorometholone or cortisdin or flucon or fluoro-ophtal or fml or pms-fluorometholone or fluoropos or oxylone).ti,ab.

37. (fluprednisolone or alphadrol).ti,ab.

38. (Flurandrenolone or flurandrenolide or cordran or haelan or fludroxycortide).ti,ab.

39. (melengestrol acetate or melengestrol).ti,ab.

40. (Methylprednisolone or metipred or medrol or urbason or medrone or solu-medrone or depo-medrone).ti,ab.

41. (a-methapred or solu-medrol or solumedrol or urbason-soluble or urbasonsoluble).ti,ab.

42. Prednisolone/

43. (Prednisolone or di-adreson-f or diadresonf or predate or predonine or cortalone or delta-cortef or fernisolone-p or meti-derm or prelone or sterane).ti,ab.

44. (Prednisone or dehydrocortisone or delta-cortisone or prednison galen or prednison hexal or pronisone or rectodelt or apoprednisone or cortancyl or panafcort or dacortin or deltasone or prednidib or predni tablinen or panasol or orasone or meticorten or liquid pred or kortancyl or enkortolon or encortone or encorton or prednison acsis or predniment or decortisyl or cutason or cortan or winpred or ultracorten or sone or sterapred or delta-dome or fernisone or paracort or predincen-m or servisone).ti,ab.

45. or $/ 28-44$

46. (Cyclizine or marezine or valoid).ti,ab.

47. Chlorpromazine/

48. (Chlorpromazine or propaphenin or aminazine or chlordelazine or contomin or largactil or fenactil or chlorazine or thorazine or thorazine).ti,ab.

49. (Domperidone or domperidon or apo-domperidone or domidon or domperidon-teva or gastrocure or motilium or nauzelin or novodomperidone or nu-domperidone or pms-domperidone or peridys or ratio-domperidone).ti,ab.

50. (Droperidol or dehydrobenzperidol or droleptan or dehidrobenzperidol or inapsine or inapsine).ti,ab. 
51. Haloperidol/

52. (Haloperidol or haldol or dozic or serenace).ti,ab.

53. (Methotrimeprazine or levomeprazin or levopromazine or levomepromazine or tisercin or tizertsin or tizercine or levoprome or nozinan).ti,ab.

54. (Metoclopramide or metaclopramide or metaclopromide or cerucal or maxolon or primperan or raglan or rimetin).ti,ab.

55. Perphenazine/

56. (Perphenazine or chlorpiprazine or perfenazine or trilafon or fentazin).ti,ab.

57. Prochlorperazine/

58. (Prochlorperazine or compazine or stemetil or buccastem or compro).ti,ab.

59. Trifluoperazine/

60. (Trifluoperazine or trifluoroperazine or trifluperazine or stelazine or triftazin or apo-trifluoperazine or apotrifluoperazine or eskazine or flupazine or terfluzine).ti,ab.
61. or $/ 46-60$
62. granisetron.ti,ab.
63. (odansetron or ondansetron).ti,ab.
64. tropisetron.ti,ab.
65. dolasetron.ti,ab.
66. anzemet.ti,ab.
67. (kytril or Eutrom or Kevatril or Taraz).ti,ab.
68. (zofran or Zofrene or Zophran or Zophren or Avessa or Ceramos).ti,ab.
69. $5-\mathrm{HT}_{3}$ antagonist $\$$.ti,ab.
70. $5-\mathrm{HT}_{3}$ blocker\$.ti,ab.
71. $\operatorname{or} / 62-70$
72. 24 or 27 or 45 or 61 or 71

73. (infant or infan\$ or newborn or newborn\$ or new-born\$ or baby or baby\$ or babies or neonat\$ or child or child\$ or schoolchild \$ or schoolchild or school child or school child $\$$ or kid or kids or toddler $\$$ or adolescent or adoles $\$$ or teen\$ or boy or girl\$ or minors or minors $\$$ or underag $\$$ or under ag $\$$ or juvenil\$ or youth $\$$ or kindergar $\$$ or puberty or puber $\$$ or pubescen\$ or prepubescen $\$$ or prepuberty \$ or pediatrics or pediatric $\$$ or paediatric $\$$ or peadiatric $\$$ or schools or nursery school\$ or preschool\$ or pre school\$ or primary school\$ or secondary school\$ or elementary school\$ or elementary school or high school\$ or highschool\$ or school age or schoolage or school age \$or schoolage\$ or infancy or schools, nursery or infant, newborn).ti,ab.
74. Nausea/
75. nausea.ti,ab.
76. vomiting/
77. vomit\$.ti,ab.
78. emesis.ti,ab.
79. sickness.ti,ab.
80. or/74-79
81. randomized.ti,ab.

Antiemetic medication for prevention and treatment of chemotherapy-induced nausea and vomiting in childhood (Review) 

82. placebo.ti,ab.
83. random\$.ti,ab.
84. trial\$.ti,ab.
85. groups.ti,ab.
86. Clinical Trials/
87. or $/ 81-86$
88. exp neoplasms/
89. cancer\$.ti,ab.
90. neoplas\$.ti,ab.
91. oncolog\$.ti,ab.
92. malignan\$.ti,ab.
93. tumo?r\$.ti,ab.
94. carcinoma\$.ti,ab.
95. adenocarcinoma\$.ti,ab.
96. sarcoma\$.ti,ab.
97. leuk?mia.ti,ab.
98. chemotherap\$.ti,ab.
99. or/88-98
100. 72 and 73 and 80 and 87 and 99

[\$=zero or many characters; ?=one or many characters; ti,ab=title or abstract; $m p=t i t l e$, abstract, subject headings, heading word, drug trade name, original title, device manufacturer or drug manufacturer name; /= Psyclnfor thesuarus term; ?= ]

\section{Appendix 2. Search strategies for proceedings abstracts}

\section{Search used in American Society of Clinical Oncology}

All meetings were searched except for the breast and prostate specific meetings (since these were expected to yield results that involved adults).

Separate searches were done for the following search terms:

nausea

vomit

emesis

emetic

antiemetic

The searches were limited to the title field and the results were deduplicated.

International Society of Paediatric Oncology (SIOP)

The site was browsed.

PDFs of the abstracts were downloaded and the text was searched for "vomiting"

\section{Multinational Association of Supportive Care in Cancer (MASCC)}

The site was browsed 


\section{ISI Proceedings: Science and Technology}

\#1 TS=( infan ${ }^{\star}$ or newborn ${ }^{\star}$ or (new same born ${ }^{\star}$ ) or baby ${ }^{\star}$ or babies or neonat ${ }^{\star}$ or child ${ }^{\star}$ or schoolchild* or (school same child ${ }^{\star}$ ) or kid or

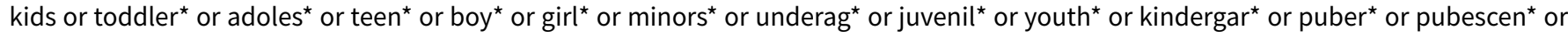

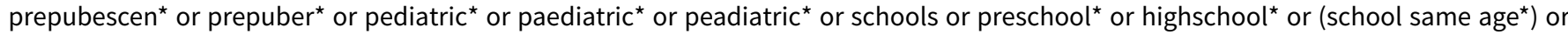
schoolage*)

\#2 TS=(nausea or vomit*or emesis or sickness)

\#3 TS=(cancer ${ }^{\star}$ or neoplas ${ }^{\star}$ or oncolog* or malignan* or tumor $^{\star}$ or tumour ${ }^{\star}$ or carcinoma* or adenocarcinoma* or sarcoma* or leukaemia or leukemia or chemotherap ${ }^{\star}$ )

$\# 1$ and \#2 and \#3

$\left[{ }^{\star}=\right.$ zero or many characters $]$

\section{Appendix 3. Search strategies for trial registers}

\section{International Cancer Research Portfolio}

The following selections were made:

Project Type=Clinical Trial

Type of Research=6.1 Cancer Control, Survivorship and Outcomes Research - Patient Care and Survivorship Issues

There was a limit on the number of terms that could be entered in the search box, so the searching was done in the following batches:

(N.B. the default is to "OR" all terms)

Search one:

Benzodiazepine\$ Alprazolam Alprazolan alprox esparon apo-alpraz apoalpraz cassadan kalma novo-alprazol novoalprazol nu-alpraz nualpraz ralozam xanax tafil trankimazin Niravam Anthramycin antramycin Bromazepam anxyrex apo-bromazepam bromalich bromaz bromazanil bromazep lexotan lexomil lexotanil lexatin durazanil gen-bromazepam

Search two:

Clonazepam antelepsin rivotril klonopin Devazepide Diazepam apaurin diazemuls faustan relanium seduxen sibazon stesolid valium rimapam tensium dialar valclair diastat dizac q-pam valrelease Nordazepam demethyldiazepam desmethyldiazepam deoxydemoxepam nordiazepam norprazepam dealkylprazepam

Search three:

calmday nordaz tranxilium Flumazenil flumazepil romazicon anexate lanexat Anexate Lorazepam apo-lorazepam apolorazepam ativan orfidal temesta donix duralozam durazolam idalprem laubeel lorazep von ct novo-lorazem novolorazem nu-loraz nuloraz sedicepan sinestron

Search four:

somagerol tolid loraz Flunitrazepam fluridrazepam flunitrazepam-teva flunizep flunimerck flunitrazepam-neuraxpharm flunitrazepamratiopharm fluninoc rohypnol narcozep rohipnol flunibeta Flurazepam dalmane Dormodor dalmadorm staurodorm apo-flurazepam Nitrazepam Nitrodiazepam

Search five:

alodorm dormalon dormo-puren eatan imadorm imeson mogadon nitrazadon nitrazep novanox radedorm remnos rhoxal-nitrazepam serenade somnite Oxazepam adumbran serax tazepam Pirenzepine pirenzepin pyrenzepine ulcoprotect ulgescum gastrotsepin pirenbasan

Search six:

pirenzepin-ratiopharm gastrozepin Prazepam centrax demetrin lysanxia reapam Temazepam hydroxydiazepam methyloxazepam oxydiazepam pronervon remestan restoril apo-temazepam euhypnos planum levanxol pms-temazepam nu-temazepam novo-temazepam nortem normitab

Search seven: 
normison nocturne temtabs gen-temazepam dasuen signopam temaze temazep tenox temaz Chlordiazepoxide methaminodiazepoxide chlozepid elenium librium a-poxide chlordiazachel librelease libritabs lygen Chlorazepate tranxene tranxilium Estazolam nuctalon prosom tasedan

Search eight:

Medazepam nobrium rudotel rusedal Midazolam dormicum versed hypnovel Triazolam apo-triazo gen-triazolam halcyon halcion trilam cannabinoid\$ canabinoid\$ Tetrahydrocannabinol thc marinol nabilone cesamet Beclomethasone beclometasone qvar aerobec beclazone ecobec

Search nine:

filair aerobec nasobec prolair respocort ventolair vancenase vanceril aldecin viarin apo-beclomethasone ascocortonyl beclamet beclocort beclomet beclorhinol becloturmant sanasthmax beclovent beconase propaderm sanasthmyl becodisks becotide becloforte

\section{Search 10:}

bronchocort junik asmabec beclazone clenil Betamethasone betadexamethasone flubenisolone celeston celestona celestone cellestoderm Betnelan betnesol flubenisolonvalerate betnovate Beta-val betaderm betatrex dermabet luxiq valisone valnac betacap betamethasone

\section{Search 11:}

valerate bettamousse diprosone Budesonide horacort pulmicort rhinocort novolizer entocort Dexamethasone hexadecadrol methylfluorprednisolone dexpak maxidex decaject decameth decaspray dexasone hexadrol millicorten oradexon aeroseb-dex decaderm dexamethasone decadron

Search 12:

decadron mymethasone auxison Flumethasone fluorodexamethasone locorten Fluorometholone cortisdin flucon fluoro-ophtal fml pms-fluorometholone fluoropos oxylone fluprednisolone alphadrol Flurandrenolone flurandrenolide cordran haelan fludroxycortide melengestrol acetate melengestrol

Search 13:

Methylprednisolone metipred medrol urbason medrone solu-medrone depo-medrone a-methapred solu-medrol solumedrol urbasonsoluble urbasonsoluble Prednisolone di-adreson-f diadresonf predate predonine cortalone delta-cortef fernisolone-p meti-derm prelone sterane Prednisone

\section{Search 14:}

dehydrocortisone delta-cortisone prednison pronisone rectodelt apo-prednisone cortancyl panafcort dacortin deltasone prednidib predni panasol orasone meticorten kortancyl enkortolon encortone encorton predniment decortisyl cutason

\section{Search 15:}

levomepromazine tisercin tizertsin tizercine levoprome nozinan Metoclopramide metaclopramide metaclopromide cerucal maxolon primperan raglan rimetin Perphenazine chlorpiprazine perfenazine trilafon fentazin Prochlorperazine compazine stemetil buccastem compro Trifluoperazine

\section{Search 16:}

trifluoroperazine trifluperazine stelazine triftazin apo-trifluoperazine apotrifluoperazine eskazine flupazine terfluzine

\section{Search 17:}

5- $\mathrm{HT}_{3}$ antagonists $5-\mathrm{HT}_{3}$ antagonist 5- $\mathrm{HT}_{3}$ blockers 5- $\mathrm{HT}_{3}$ blocker

Search 18:

granisetron ondansetron ondansetron tropisetron dolasetron anzemet kytril Eutrom Kevatril Taraz zofran Zofrene Zophran Zophren Avessa Ceramos

[\$=zero or more characters] 


\section{National Cancer Institute Clinical Trials PDQ}

The interface uses menu selections there is no free text searching. The following selections were made:

Type of cancer:all

Type of trial:supportive care

Status of trial:active/closed (this was an either/or situation the same search was run twice once for active, once for closed)

Type of treatment:chemotherapy

Drug:alprazolam, lorazepam, midazolam, midazolam hydrochloride, cannabinol, tetrahydrocannabinol, beclomethasone dipropionate, budesonide, dexamethasone, Sk-Dexamethasone, 6Alpha-Methylprednisolone, 9alpha-Fluoro-16alpha- methylprednisolone, 9Alphafluoro-16alpha-methylprednisolone, methylprednisolone, Methylprednisolone Acetate, Methylprednisolone Succinate, prednisolone, prednisone, Sk-Prednisone, chlorpromazine, domperidone, droperidol, haloperidol, metoclopramide hydrochloride, prochlorperazine, trifluoperazine hydrochloride

Drug combination search:no

Phase of trial:all

Sponsor of trial:all

Special category: all

\section{National Cancer Research Institute (NCRI)}

The site was browsed.

\section{Current Controlled Trials (mRCT Register)}

(cancer\% OR neoplas\% OR oncolog\% OR malignan\% OR tumor\% OR tumour\% OR carcinoma\% OR adenocarcinoma\% OR carcoma\% OR leukaemia OR leukemia OR chemotherap \%) and (nausea OR vomit $\%$ OR emesis OR sickness)

[\%=zero or many characters]

\section{Search used in Clinical Trials.gov}

(Cancer OR carcinoma OR leukaemia OR leukemia) and (nausea OR vomit)

\section{Centerwatch}

The interface uses a combination of menu selections and free text searching. The following selection was made:

Disease or condition: Cancer/Chemotherapy

All other boxes were left blank.

Keywords used were: vomit or nausea or emesis or sickness

WHAT'S NEW

\begin{tabular}{|c|c|c|}
\hline Date & Event & Description \\
\hline \multirow[t]{3}{*}{15 September 2015} & New citation required but conclusions & Summary of most important changes in the update: \\
\hline & & $\begin{array}{l}\text { The search for eligible studies was updated to December } 2014 \text {; } \\
\text { we identified six new studies. They included comparisons of dif- } \\
\text { ferent } 5-\mathrm{HT}_{3} \text { antagonists, and the addition of further agents to } 5-\end{array}$ \\
\hline & & $\begin{array}{l}\mathrm{HT}_{3} \text { antagonist 'backbone' antiemetic strategies (including tra- } \\
\text { ditional Chinese medicine, anxiolytics, and other antiemetics). } \\
\text { These new studies did not meaningfully alter the conclusions of } \\
\text { the } 2010 \text { review. }\end{array}$ \\
\hline
\end{tabular}




\begin{tabular}{lll}
\hline Date & Event & Description \\
\hline 2 January 2015 & New search has been performed & The search for eligible studies was updated to December 2014. \\
\hline
\end{tabular}

\section{H I S T ORY}

Protocol first published: Issue 2, 2009

Review first published: Issue 9, 2010

\begin{tabular}{lll}
\hline Date & Event & Description \\
\hline 18 January 2011 & Amended & Contact details updated.
\end{tabular}

\section{CONTRIBUTIONS OF AUTHORS}

RSP took part in protocol development, search formulation, initial screening, data extraction and data synthesis, and drafted the report.

AJF undertook screening and data extraction of the 2014 update, and drafted the updated report.

FG took part in protocol development and drafted the report.

EH undertook data extraction and data synthesis.

SG undertook screening and data extraction, and drafted the report.

JVC took part in protocol development and data extraction.

BP took part in protocol development, undertook data extraction and synthesis, and drafted the report.

All review authors have contributed to the final report.

\section{DECLARATIONS OF INTEREST}

RSP: no financial conflicts of interest

AJF: no financial conflicts of interest

FG: no financial conflicts of interest

EH: no financial conflicts of interest

SG: no financial conflicts of interest

JVC: no financial conflicts of interest

BP: no financial conflicts of interest

\section{SOURCES OF SUPPORT}

\section{Internal sources}

- Candlelighters: The Yorkshire Children's Cancer Charity, UK.

Financial support for RSP and the conduct of the original review

\section{External sources}

- No sources of support supplied 


\section{DIFFERENCES BETWEEN PROTOCOLAND REVIEW}

1. The objectives were clarified; the overarching aim was supplemented with specific objectives.

2. We explicitly excluded non-pharmacological therapies in the text of this review, instead of implying it in the text of the protocol.

3. We used marginally different search filters. After discussion within the team, it was felt that the Centre for Reviews and Dissemination (CRD) search filters, which are used to undertake many Health Technology Appraisal reports from the CRD, were the most appropriate filters to apply. Sampling 200 random citations 'missed' with the CRD filter did not demonstrate any additional relevant studies.

4. During data extraction we also collected data on "potential for selective reporting of outcomes" and "other potential sources of bias" (particularly in respect to cross-over studies). This was advised following the initial protocol.

5. The explicit analysis of outcomes to assess for the effect of potential sources of bias, including publication bias, was undertaken but not explicitly stated in the original protocol.

6. We stated that we would not assess any outcome where more than $50 \%$ of participants did not have that outcome. In no trial was there a drop-out rate that high, and so we did not drop any assessments for this reason.

7. We did not specify the type of analysis of paired/cross-over data in the protocol.

\section{INDEX TERMS}

\section{Medical Subject Headings (MeSH)}

Antiemetics [adverse effects] [ ${ }^{*}$ therapeutic use]; Antineoplastic Agents [ ${ }^{*}$ adverse effects]; Dexamethasone [therapeutic use]; Drug Therapy, Combination [adverse effects] [methods]; Nausea [chemically induced] [*drug therapy] [ ${ }^{*}$ prevention \& control]; Neoplasms [drug therapy]; Randomized Controlled Trials as Topic; Serotonin Antagonists [adverse effects] [therapeutic use]; Vomiting [chemically induced] [*drug therapy] [ ${ }^{*}$ prevention \& control]

\section{MeSH check words}

Adolescent; Child; Humans 